FABIO JOSE MICERINO

IMPACTO DA UTILIZAÇÃO DE MOTORES DE ALTO RENDIMENTO E SUA APLICAÇÃO NO LEILÃO DE EFICIÊNCIA ENERGÉTICA 
FABIO JOSE MICERINO

\section{IMPACTO DA UTILIZAÇÃO DE MOTORES DE ALTO RENDIMENTO E SUA APLICAÇÃO NO LEILÃO DE EFICIÊNCIA ENERGÉTICA}

Dissertação apresentada à Escola Politécnica da Universidade de São Paulo para obtenção do título de Mestre em Engenharia

Área de concentração:

Sistemas de Potencia

Orientador: Prof. Dr. Silvio Ikuyo Nabeta 


\section{DEDICATÓRIA}

Dedico este trabalho aos meus finados pais José Micerino e Teresa Fabro Micerino 


\section{AGRADECIMENTOS}

Ao professor Dr. Silvio Ikuio Nabeta pela paciencia e dedidação em me orientar neste trabalho e pela sua grande simpatia de uma pessoa sábia e humilde.

Ao prof. Saidel pelas dicas e sacadas que me ajudaram muito neste trabalho.

Ao prof. Galvão que com sua análise criteriosa me ajudou a melhorar meu trabalho.

Ao prof. Rocco, pelos ensimamentos na graduação, dos quais tive muito orgulho de estar presente nas aulas e ter aprendido coisas que me serviram e me servirão por toda a vida em minha profissão de engenheiro eletricista.

Em especial a minha esposa Kelly que sempre me apoiou em meus estudos e nunca exitou em me ajudar nos momentos difíceis para a conclusão deste trabalho.

Ao meu amigo Tom, o qual devo muitas alegrias e alguns passeios incríveis. 
Nada é complicado se nos prepararmos previamente.

(Confúcio) 


\section{RESUMO}

O trabalho apresentado tem como objetivo principal pesquisar e demonstrar através de simulações as implicações da utilização de motores de alto rendimento com viés de Eficiência Energética. Além disso, pretende-se estabelecer uma ligação entre o uso eficiente da energia com a possibilidade dos leilões de eficiência energética virem a se tornar uma realidade no Brasil. É de fudamental importância que se tenha a preocupação com sistemas de conservação de energia e não somente com novas fontes de geração. A eficiência Energética vem ganhando cada vez mais espaço no setor elétrico, se tornando muito mais que um indicador mas também uma forma de tornar o sistema mais robusto e capaz de suprir deficiências por problemas estruturais. Procurou-se demontrar o cenário atual da matriz energética atual, conceituar leilões de eficiência energética e os certificados brancos que é um subproduto deste. Por fim, realizou-se várias simulações estudando a substituição dos motores de alto rendimento e os ganhos técnicos e financeiros atrelados aos leilões de eficiência energética. Além disso, foi demonstrado também o impacto da utilização dos motores de alto rendimento em leilões de eficiência energética por segmentos da industria brasileira.

Palavras-chave: Motores de alto rendimento. Eficiência energética. Leilões de eficiência energética. 


\begin{abstract}
The present study has as main objective the analysis, through simulations, of the implications of the use of energy efficient motors with a bias of energy Efficiency . In addition, we intend to establish a link between the efficient use of energy with the possibility of auctions for energy efficiency become a reality in Brazil. It is also important to have concerns with energy conservation systems and not only with new sources of generation. Energy efficiency is becoming an increasingly common concern in the electricity sector, being much more than an indicator but also a way to make the system more robust and capable of mitigating deficiencies which occur by structural problems. In this work We tried to present the current energy scenario and define the energy efficiency auctions as well as its byproduct, the "white certificates". Finally, we carried out several simulations studying the replacement of common electrical motors by high efficiency ones in order to analyse the technical and the financial gains linked to energy efficiency auctions. In addition, we also demonstrated the impact of the use of high efficiency motors by sectors of brazilian industry in the energy efficiency auctions.
\end{abstract}

Keywords: High-efficiency motors. Energy efficiency. Auctions for energy efficiency. 


\section{LISTA DE GRÁFICOS}

Gráfico 3.2.1 - Expansão da capacidade instalada vs. Crescimento da demanda

Gráfico 3.3.1 - Aumento da tarifa industrial média de energia elétrica no Brasil.

Gráfico 3.3.2 - Tarifa industrial média de energia elétrica em vários países.

Gráfico 4.7.1 - Consumo de energia elétrica por setor 35

Gráfico 4.7.2 - Peso do potencial de conservação de energia elétrica de cada setor em relação ao potencial total.

Gráfico 6.5.2.1 - Diferenças de rendimento (\%) e de preço (R\$) entre motores standard e motores de alto rendimento por potencia e $\mathrm{n}^{\circ}$ de pólos.....58

Gráfico 6.5.2.1.1 - Definição do mercado para motores de alto rendimento. 59

Gráfico 6.5.2.1.2 - Segmentação no mercado de alto rendimento 60 Gráfico 7.1.1 - Mercado potencial para substituição por motores de alto rendimento 71

Gráfico 8.10.1 - Potencial de economia energética por setor (GWh). 105

Gráfico 8.10.2 - Análise de atratividade de cada setor. 107 


\section{LISTA DE TABELAS}

Tabela 4.2.2.1 - Indicador de Eficiência Energética

de Motores

Tabela 4.7.1 - Potencial de conservação de energia elétrica por setor

da economia brasileira (GWh).

Tabela 6.5.1 - Participação da força motriz no consumo elétrico

da indústria

Tabela 6.5.1.1 - Economia obtida através do correto dimensionamento

do motor.

Tabela 6.5.1.2 - Critérios mais frequentes para dimensionamento

de motores

Tabela 6.5.2.4.1 - Parametros operacionais e comparação entre

motores standard e de alto rendimento.

Tabela 6.5.2.4.2 - Análise do investimento.

Tabela 6.5.2.4.3 - Resultado da análise do investimento.

Tabela 7.2.1 - Estimativa do $n^{\circ}$ de motores em operação na indústria

brasileira

Tabela 7.3.1 - Comparação da composição do parque industrial de

Brasil, Estados Unidos e União Europeia por classe de potencia

(em CV).

Tabela 7.3.2 - Estimativa da composição do parque industrial brasileiro, por setor e classe de potencia (cenário mínimo).

Tabela 7.3.3 - Estimativa da composiçao do parque industrial brasileiro,

por setor e classe de potencia (cenário máximo).

Tabela 7.4.1 - Estimativa da quantidade de motores a entrar em

funcionamento, por setor e classe de potencia (cenário mínimo).

Tabela 7.4.2 - Estimativa da quantidade de motores a entrar em

funcionamento por setor e classe de potencia (cenário máximo). .84

Tabela 7.5.1 - Vida útil e probabilidade de avaria anual por motor. .85

Tabela 7.6.1 - Taxa de reparação por escala de potencia. .86

Tabela 7.6.2 - Estimativa da quantidade de motores a substituir por avaria 
por setor e classe de potencia (cenário mínimo).

Tabela 7.6.3 - Estimativa da quantidade de motores a substituir por

avaria por setor e classe de potencia (cenário máximo).

Tabela 7.7.1 - Estimativa do consumo atual dos motores a substituir por

avaria, por setor e classe de potencia (cenário mínimo, em GWh).

Tabela 7.7.2 - Estimativa do consumo atual dos motores a substituir por

avaria, por setor e classe de potencia (cenário máximo, em GWh).

Tabela 7.7.3 - Estimativa do consumo potencial dos motores a substituir

por avaria se todos fossem de alto rendimento, por setor e classe de

potencia (cenário mínimo, em GWh).

Tabela 7.7.4 - Estimativa do consumo potencial dos motores a substituir

por avaria se todos fossem de alto rendimento, por setor e classe de

potencia (cenário máximo, em GWh).

Tabela 7.7.5 - Estimativa da economia de energia elétrica potencial com

motores a substituir por avaria anualmente, por setor e classe de

potencia (cenário mínimo, em GWh).....

Tabela 7.7.6 - Estimativa da economia de energia elétrica potencial com

motores a substituir por avaria, por setor e classe de potencia

(cenário máximo, em GWh).

Tabela 7.7.7 - Estimativa do consumo potencial com motores a

entrar em funcionamento, por setor e classe de potencia

(cenário mínimo, em GWh)....

Tabela 7.7.8 - Estimativa do consumo potencial com motores a

entrar em funcionamento, por setor e classe de potencia

(cenário máximo, em GWh).

Tabela 7.7.9 - Estimativa do consumo potencial com motores a

entrar em funcionamento se todos fossem de alto rendimento, por

setor e classe de potencia (cenário mínimo, em GWh).

Tabela 7.7.10 - Estimativa do consumo potencial com motores a entrar em funcionamento se todos fossem de alto rendimento por setor e classe de potencia (cenário máximo, em GWh)

Tabela 7.7.11 - Estimativa da economa de energia elétrica potencia com motores a entrar em funcionamento, por setor e classe de potencia (cenário mínimo, em GWh). 
Tabela 7.7.12 - Estimativa da economia de energia elétrica potencial com motores a entrar em funcionamento, por setor e classe de potencia (cenário máximo, em GWh).

Tabela 7.7.13 - Estimativa da economia de energia elétrica potencial no parque industrial brasileiro, por setor e classe de potencia (cenário mínimo, em GWh).

Tabela 7.7.14 - Estimativa da economia de energia elétrica potencial no parque industrial brasileiro, por setor e classe de potencia (cenário máximo, em GWh).

Tabela 7.8.1 - Estimativa do custo evitado com motores a substituir por avaria anualmente, por setor e classe de potencia (cenário mínimo, em milhares de $\mathrm{R} \$$ ).

Tabela 7.8.2 - Estimativa do custo evitado com motores a substituir por avaria anualmente, por setor e classe de potencia (cenário máximo, em milhares de $\mathrm{R} \$$ ). .93

Tabela 7.8.3 - Estimativa do valor para o leilão dos motores a substituir por avaria

Tabela 7.8.4 - Estimativa do valor total para o leilão dos motores a substituir por avaria anualmente, por setor e classe de potencia (cenário máximo, em milhares de $\mathrm{R} \$$ ).

Tabela 7.8.5 - Estimativa do custo evitado com motores

a entrar em funcionamento anualmente, por setor e classe de potencia (cenário mínimo, em milhares de $\mathrm{R} \$$ )... .95

Tabela 7.8.6 - Estimativa do custo evitado com motores a entrar em funcionamento anualmente, por setor e classe de potencia (cenário máximo, em milhares de $\mathrm{R} \$$ ).

Tabela 7.8.7 - Estimativa do valor total para o leilão dos motores

a entrar em funcionamento anualmente, por setor e classe de potencia (cenário mínimo, em milhares de $\mathrm{R} \$$ ) .96

Tabela 7.8.8 - Estimativa do valor total para o leilão dos motores a entrar em funcionamento anualmente, por setor e classe de potencia (cenário máximo, em milhares de $\mathrm{R} \$$ ). .96

Tabela 7.8.9 - Estimativa do custo evitado potencial existente no parque industrial brasileiro, por setor e classe de potencia 
(cenário mínimo, em milhares de $\mathrm{R} \$$ )

Tabela 7.8.10 - Estimativa do custo evitado potencial existente no parque industrial brasileiro, por setor e classe de potencia (cenário máximo, em milhares de $\mathrm{R} \$$ ).

Tabela 7.8.11 - Estimativa do valor total para o leilão dos motores existentes no parque industrial brasileiro, por setor e classe de potencia (cenário mínimo, em milhares de $\mathrm{R} \$$ )

Tabela 7.8.12 - Estimativa do valor total para o leilão dos motores existentes no parque industrial brasileiro, por setor e classe de potencia (cenário máximo, em milhares de $\mathrm{R} \$$ ).

Tabela 7.9.1 - Nível de emissões de CO2 por unidade de energia consumida ( $\mathrm{KgCO} 2 / \mathrm{KWh}$ )

Tabela 7.9.2 - Estimativa do potencial de emissões evitadas de $\mathrm{CO} 2$ com motores a substituir por avaria anualmente, por setor e classe de potencia (cenário mínimo, em toneladas de CO2). 99

Tabela 7.9.3 - Estimativa do potencial de emissões evitadas de $\mathrm{CO} 2$, com motores a substituir por avaria anualmente, por setor e classe de potencia (cenário máximo, em toneladas de $\mathrm{CO} 2$ ). 99

Tabela 7.9.4 - Estimativa do potencial de emissões evitadas de $\mathrm{CO} 2$ dos motores a entrar em funcionamento anualmente, por setor e classe de potencia (cenário mínimo, em toneladas de CO2) 100

Tabela 7.9.5 - Estimativa do potencial de emissões evitadas de $\mathrm{CO} 2$ dos motores a entrar em funcionamento anualmente, por setor e classe de potencia (cenário máximo, emtoneladas de $\mathrm{CO} 2$ ) 100

Tabela 7.9.6 - Estimativa do potencial de emissões evitadas de $\mathrm{CO} 2$ no parque industrial brasileiro, por setor e classe de potencia (cenário mínimo, em toneladas de $\mathrm{CO} 2$ ). 100

Tabela 7.9.7 - Estimativa do potencial de emissões evitadas de $\mathrm{CO} 2$ no parque industrial brasileiro, por setor e classe de potencia (cenário máximo, em toneladas de $\mathrm{CO} 2$ ). 101

Tabela 7.9.8 - Estimativa do valor potencial em créditos de CO2 com motores a substituir por avaria anualmente, por setor e classe de potencia(cenário mínimo em $\mathrm{R} \$$ ). 101

Tabela 7.9.9 - Estimativa do valor potencial em créditos de 
CO2 com motores a substituir popr avaria anualmente, por setor

e classe de potencia (cenário máximo, em $R \$$ ).

Tabela 7.9.10 - Estimativa do valor potencial em créditos de

$\mathrm{CO} 2$, com motores a entrar em funcionamento anualmente, por setor

e classe de potencia (cenário mínimo, em $\mathrm{R} \$$ ).

Tabela 7.9.11 - Estimativa do valor potencial em créditos de CO2

com motores a entrar em funcionamento anualmente, por setor

e classe de potencia (cenário máximo, em $\mathrm{R} \$$ ).

Tabela 7.9.12 - Estimativa do valor potencial em créditos de

CO2, no parque industrial brasileiro, por setor e classe de potencia

(cenário mínimo, em $\mathrm{R} \$$ )

Tabela 7.9.13 - Estimativa do valor potencial em crédito de CO2,

no parque industrial brasileiro, por setor e classe de potencia

(cenário máximo, em $\mathrm{R} \$$ ).

Tabela 8.10.1 - Peso do potencial de economia energética no

consumo de cada setor

Tabela 8.10.2 - Quadro resumo dos resultados obtidos 108

Tabela 8.10.3 - Potencial de economia de energia elétrica

com motores a substituir por avaria anualmente em cada setor,

distribuído por classe de potencia. 108

Tabela 8.10.4 - Potencial de economia de energia elétrica

com motores atualmente em operação em cada setor, distribuído

por classe de potencia

Tabela 8.10.5 - Impacto da distribuição da potencia na amostra para o consumo estimado.

Tabela 8.10.6 - Impacto da distribuição da carga na amostra para

o consumo estimado.

Tabela 8.10.7 - Impacto da distribuição do número de pólos na amostra para o consumo estimado 


\section{SUMÁRIO}

1. INTRODUÇÃO

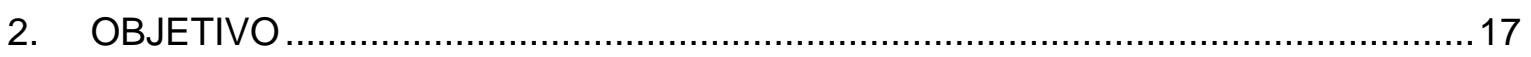

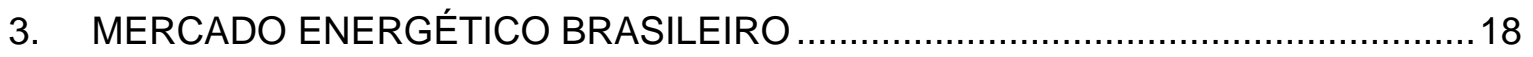

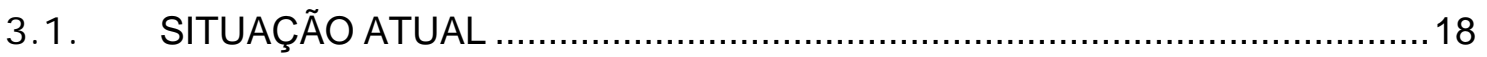

3.2. PROJEÇÕES PARA O FUTURO - CAPACIDADE VS. DEMANDA ..............20

3.3. OUTROS DESAFIOS PARA A INDÚSTRIA DA ENERGIA ...........................21

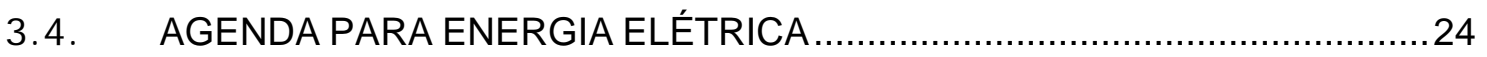

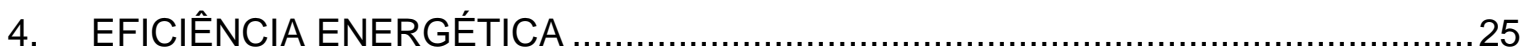

4.1. INTRODUÇÃO - CONCEITOS FUNDAMENTAIS......................................25

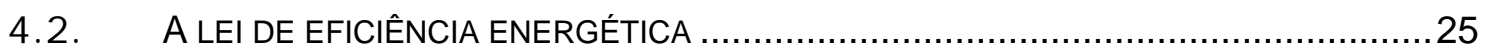

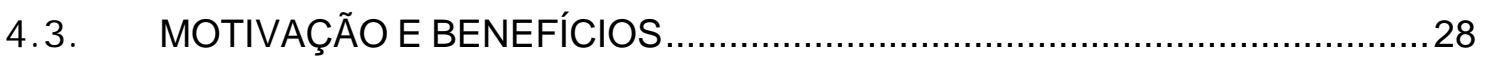

4.4. PROMOÇÃO DA EFICIÊNCIA ENERGÉTICA NO BRASIL ...........................30

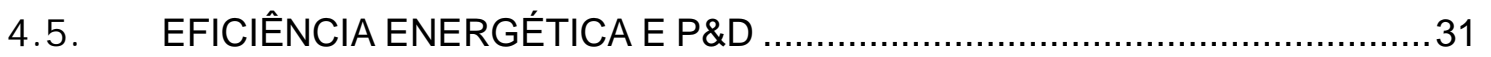

4.6. O MERCADO DE EFICIÊNCIA ENERGÉTICA ............................................34

4.7. POTENCIAL DE EFICIÊNCIA ENERGÉTICA NO BRASIL …..........................35

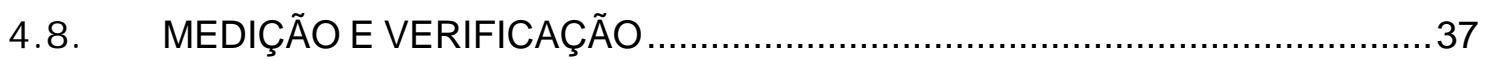

4.9. PRINCIPAIS LIÇÕES DA EXPERIÊNCIA INTERNACIONAL .......................39

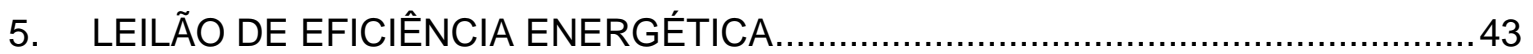

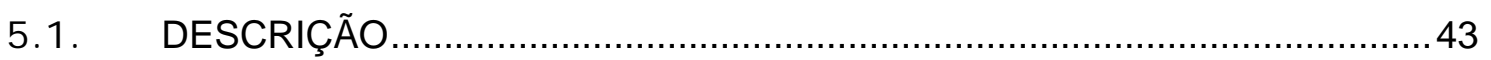

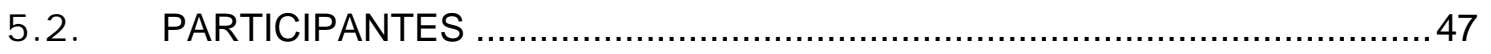

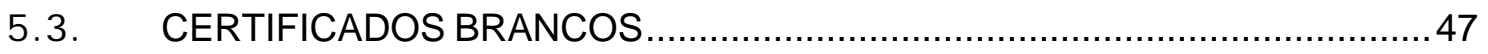

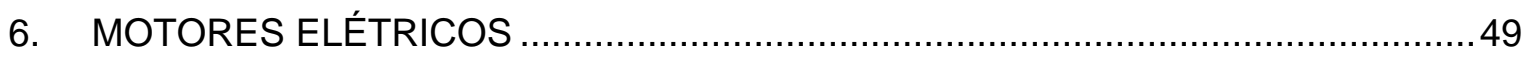

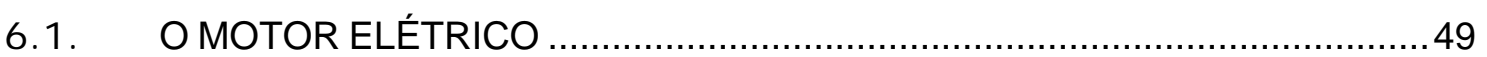

6.2. MERCADO DE MOTORES ELÉTRICOS NO BRASIL ..................................49

6.3. TIPOS DE MOTORES MAIS COMUNS ……................................................. 50

6.4. A IMPORTÂNCIA DO MOTOR DE INDUÇÃO TRIFÁSICO DE GAIOLA .......51

6.5. MOTORES ELÉTRICOS E EFICIÊNCIA ENERGÉTICA NA INDÚSTRIA .....52

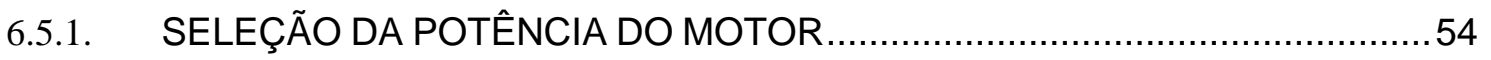

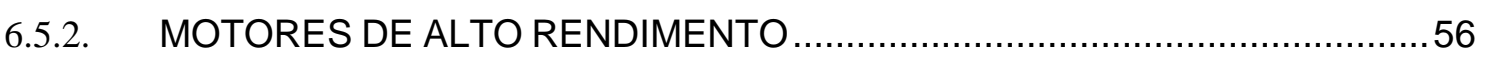

6.5.2.1. MERCADO PARA MOTORES DE ALTO RENDIMENTO …...........................59

6.5.2.2. ANÁLISE DA VIABILIDADE ECONÔMICA DA SUBSTITUIÇÃO ...................60 


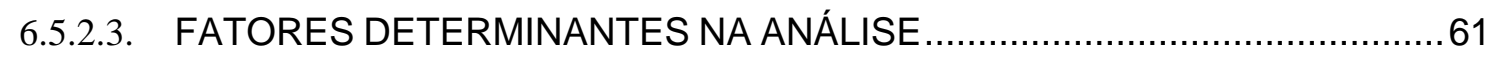

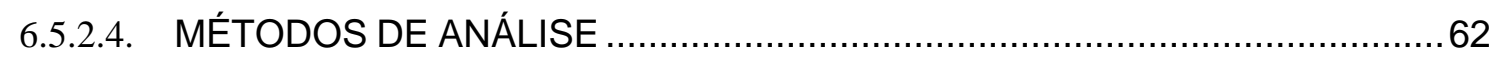

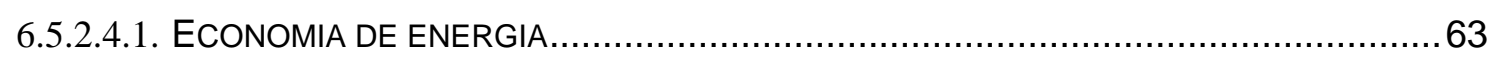

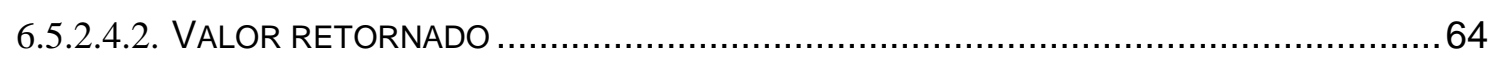

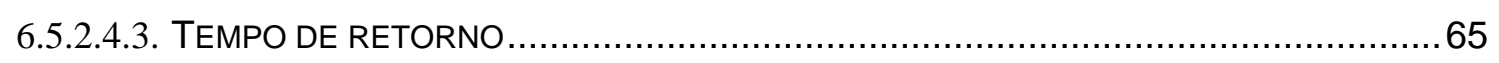

7. SUBSTITUIÇÃO DE MOTORES COMO FORMA DE POTENCIALIZAR O LEILÃO

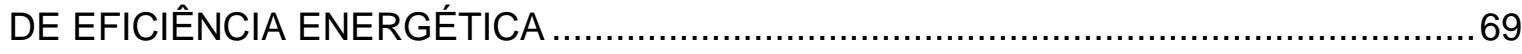

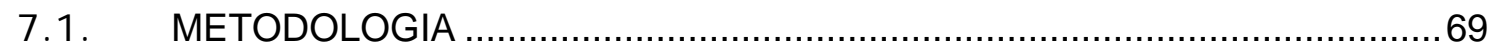

7.1.1. MODELO DO PARQUE INDUSTRIAL DE MOTORES …............................ 75

7.2. ESTIMATIVA DO № TOTAL DE MOTORES EM OPERAÇÃO ......................79

7.3. ESTIMATIVA DO NN DE MOTORES POR SETOR INDUSTRIAL ................... 82

7.4. ESTIMATIVA DO № DE MOTORES A ENTRAR EM FUNCIONAMENTO POR

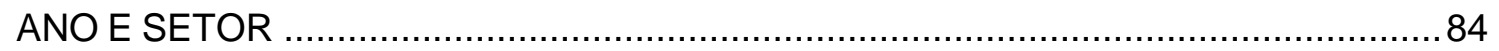

7.5. ESTIMATIVA DO № DE AVARIAS POR ANO E SETOR …............................. 85

7.6. ESTIMATIVA DO NN DE SUBSTITUIÇÕES POR ANO E SETOR .................... 85

7.7. ESTIMATIVA DO POTENCIAL DE CONSERVAÇÃO .................................... 88

7.8. CUSTO EVITADO E VALOR TOTAL DO MERCADO PARA LEILÃO .............93

7.9. EMISSÕES DE CO ${ }_{2}$ EVITADAS E VALOR POTENCIAL EM CRÉDITOS DE $\mathrm{CO}_{2} \quad 98$

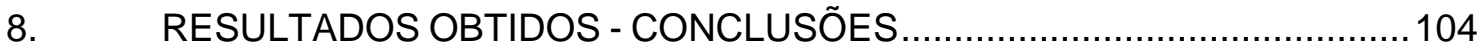

8.1. IMPLEMENTAÇÃO DESTE TRABALHO - LINHA DE ATUAÇÃO …..........................110

8.1.1. DISTRIBUIÇÃO DE MOTORES POR ESCALA DE POTÊNCIA .................................. 110

8.1.2. DISTRIBUIÇÃO DE MOTORES POR CARGA SUPORTADA …............................ 111

8.1.3. DISTRIBUIÇÃO DE MOTORES POR TIPO (STANDARD VS. ALTO RENDIMENTO) .......112

8.1.4. DISTRIBUIÇÃO DE MOTORES POR TEMPO MÉDIO DE OPERAÇÃO ANUAL ..............113

8.1.5. DISTRIBUIÇÃO DE MOTORES POR IDADE .............................................. 113

8.1.6. DISTRIBUIÇÃO POR NÚMERO DE PÓLOS................................................... 114

8.1.7. VIDA ÚTIL, TAXAS DE AVARIA E TAXAS DE REPARAÇÃO .................................114

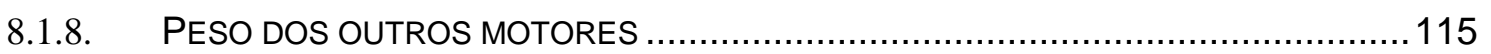

8.1.9. OEMS - ORIGINAL EQUIPMENT MANUFACTURERS ...................................... 116

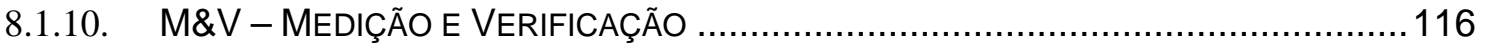

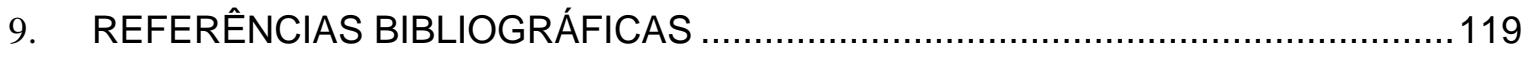




\section{INTRODUÇÃO}

As questões ambientais, assim como a sustentabilidade da exploração e utilização dos recursos naturais, estão cada vez está mais presente nos dias atuais. Isso não ocorre só na mídia, como também nas empresas e até nas próprias ações de cada um. De fato, ao longo das últimas décadas, várias regulamentações foram sendo aprovadas em todo o mundo, assim como várias normas, que gradualmente foram sendo instituídas no sentido de defender 0 nosso planeta e os seus inestimáveis recursos. Na origem da instituição destas regulamentações não só tomaram parte governos e instituições supra governamentais, como também as próprias empresas, as quais estão sujeitas, cada vez mais, às fortes pressões da opinião pública.

Dentro daquelas políticas que se convencionaram como sendo de sustentabilidade e responsabilidade social, diversas áreas foram sendo definidas e estudadas. Dentro deste amplo cenário, este trabalho pretende abordar a área da eficiência energética e, mais especificamente, sobre formas de expandir e potencializar o seu desenvolvimento no Brasil, sobretudo no parque industrial. 


\section{OBJETIVO}

Este trabalho pretende estudar o impacto que a utilização de motores de alto rendimento poderia ter na eventualidade de os leilões de eficiência energética no Brasil se tornar uma realidade.

É sabido que os motores de alto rendimento apresentam, face aos predominantes motores standard, um rendimento bastante superior, melhorando o índice de eficiência energética de qualquer aplicação que beneficie deles. Deste modo, pretende-se investigar se a substituição de motores standard por motores de maior rendimento, com todos os ganhos econômicos e energéticos subjacentes, representa uma alternativa válida para a dinamização dos leilões de eficiência energética. 


\section{MERCADO ENERGÉTICO BRASILEIRO}

\subsection{SITUAÇÃO ATUAL}

No Brasil, cerca de $76,9 \%$ da capacidade instalada de geração é proveniente de usinas hidrelétricas, enquanto que apenas 15\% provêm de outras fontes de geração de energia elétrica. Atualmente, dentro da geração termelétrica, as principais fontes principais são gás natural, carvão, energia nuclear, e óleo.

Outras fontes, como energia eólica ou biomassa, estão sendo gradualmente introduzidas na matriz, com previsão de aumentos significativos das suas capacidades instaladas de geração para os próximos anos. No entanto, apesar desta aposta, estas fontes renováveis ainda representam uma ínfima parte da capacidade total de geração do país e sem previsão que tal se altere nos próximos anos. A capacidade instalada de outras fontes alternativas, das quais a energia solar é um bom exemplo, é praticamente desprezível, encontrando ainda alguma resistência face a outras fontes mais comuns no mercado.

No total, segundo dados de 2010, a capacidade de geração de energia elétrica no Brasil é de 112.455 MW (MME, 2011). Nesse ano, geraram-se em média 56.143 MW de potência, sendo que o consumo máximo atingiu os 71.260 MWmédios, onde para efeito de valores, 1MWmédio equivale a 720MWhoras. Esta forma de medida é comum nos mercados de operação de energia elétrica tanto para efeitos de vendas de energia como para comprovação de lastro de contratação de grandes clientes consumidores de energia elétrica.

Considerando-se a composição da matriz energética brasileira, deve-se observar a inequívoca dependência das usinas hidrelétricas e o efeito que esta tem no balanço entre oferta e demanda no sistema. De fato, para proceder a esta análise, caso o sistema gerador brasileiro fosse puramente constituído por usinas termelétricas, bastaria comparar a potência total instalada com a potência máxima consumida. Se esta fosse inferior à potência total instalada, não se correria o risco de falta de cobertura da demanda, salvo situações excepcionais. 
No caso das usinas hidrelétricas, porém, existem vários fatores que contribuem para alterar a quantidade de energia gerada. Em geral, apesar de poderem produzir a sua potência máxima nas horas de maior consumo, as usinas hidrelétricas não têm a possibilidade de gerar a sua capacidade máxima permanentemente. Assim, como consequência, uma usina hidrelétrica com a capacidade para suprir o consumo máximo não terá necessariamente possibilidade de atender o consumo médio. No caso do Brasil, este é um aspecto crítico.

De modo a contornar esse problema, foi instituído o conceito de energia firme, a qual corresponde à potência média que poderia ser gerada por uma usina hidrelétrica caso voltasse a ocorrer a pior seca jamais registrada. Assim, convencionou-se que a energia firme de uma usina hidrelétrica corresponde a $55 \%$ da sua potência instalada, enquanto que, por exemplo, no caso de uma usina térmica de ciclo combinado a gás natural, o valor é 92\%. Há que salientar, no entanto, que atualmente diversos estudos apontam para uma eventual revisão deste valor para usinas hidrelétricas, tendo em conta que várias das usinas que foram sendo construídas ao longo do tempo utilizam hoje em dia as vazões efluentes devidamente regularizadas provenientes de outros empreendimentos construídos nos mesmos rios.

Assim, se a energia firme total do sistema de geração exceder o consumo médio previsto para esse mesmo ano, então, em princípio, o suprimento de eletricidade será garantido mesmo no caso de ocorrer a pior seca observada na história (CNI, 2007). Caso ocorresse que a geração não fosse suficiente para cobrir totalmente a demanda, haveria sempre a possibilidade de importar eletricidade - como já aconteceu no caso do Brasil com a importação de eletricidade da Argentina.

Tendo em conta os dados disponíveis para o período 2007-2011, a oferta já contratada será, em princípio, suficiente para cobrir a demanda no caso de um crescimento médio de $4 \%$ do PIB. No entanto, deve se levar em conta que, por exemplo, atrasos na construção de usinas hidrelétricas, podem influenciar negativamente as previsões anteriores, reduzindo a capacidade instalada face ao esperado. Não será demais sublinhar, portanto, a contribuição e o impacto que 
medidas alternativas - tais como aquelas que melhorem a eficiência energética do sistema, promovendo um consumo mais racional de eletricidade - poderão tornar-se uma alternativa na prevenção de eventuais falhas futuras no suprimento de demanda de energia elétrica no sistema energético brasileiro.

\subsection{PROJEÇÕES PARA O FUTURO - CAPACIDADE VS. DEMANDA}

As previsões elaboradas na publicação Plano Decenal de Expansão de Energia 2019 (MME \& EPE, 2010) apontam para um crescimento médio anual da capacidade instalada total de $5,1 \%$ ao longo da próxima década.

No entanto, como já foi referido na seção 3.1 , não é seguro que isso venha a acontecer. Através da observação do Gráfico 3.2.1 e de acordo com a previsão de crescimento do país, com o Produto Interno Bruto crescendo a taxas de 3,5\% a $4,5 \%$ e o consumo de energia crescendo a taxas de $8 \%$ a $9 \%$, estima-se que a carga de energia elétrica destacada no gráfico em amarelo ultrapassará a

\section{Gráfico 3.2.1 - Expansão da capacidade instalada vs. Crescimento da demanda}

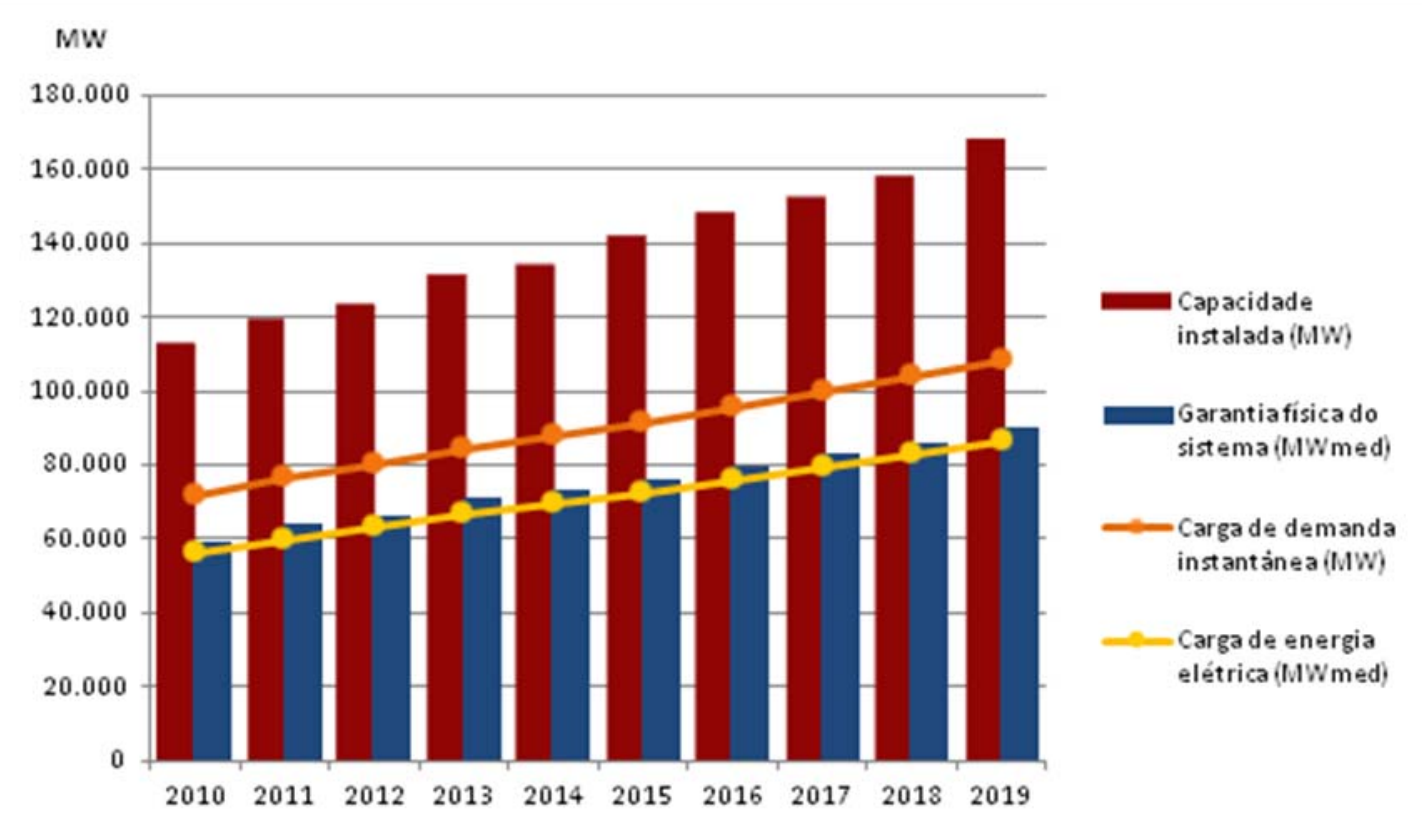

Fonte: MIME \& EPE $(2010)$ 
garantia física do sistema destacado em azul se o perfil de consumo atual se mantiver da forma que está, sem nenhuma ação de eficiência energética prevista para os próximos anos for de fato colocada em prática. De acordo com Bajay (2009), as projeções de crescimento da oferta constantes tanto no Plano Decenal de Expansão de Energia 2019 (MME \& EPE, 2010) como no Plano Nacional de Energia 2030 (MME \& EPE, 2007) dificilmente se concretizarão, sobretudo no caso das novas usinas hidrelétricas. Além do mais, como consequência do fato da maioria das novas usinas hidrelétricas serem a fio d'água, os grandes reservatórios do sistema hidrelétrico brasileiro perderam a sua capacidade de regularização plurianual, tendo esta se tornado anual, o que pode colocar em certo risco de fornecimento de energia a um baixo custo, tendo o governo e órgãos responsáveis pelo abastecimento de energia elétrica do país, recorrer a outras fontes de geração com custo mais alto, onerando todo o sistema, e em casos extremos, podendo ter problemas para de abastecimento caso venham a ter problemas de fornecimento de outros insumos energéticos como o gás, carvão mineral dentre outras utilizados para termelétricas. Desta forma, é possível verificar a grande importância dos sistemas de eficiência energética no país, vislumbrando um apoio importante para a segurança energética e redução de custos para o país.

\subsection{OUTROS DESAFIOS PARA A INDÚSTRIA DA ENERGIA}

No que toca à indústria energética, é um fato inquestionável que o Brasil é um país que dispõe de condições absolutamente excepcionais, não só relativamente à questão da segurança relativamente ao suprimento da demanda, como também no que se refere ao aspecto ambiental - i.e. tudo o que se relaciona com a adoção de energias renováveis e competitivas (CNI, 2007).

Contudo, mesmo se beneficiando de condições naturais extremamente favoráveis, dois grandes desafios ameaçam pôr em causa a competitividade do sistema energético brasileiro nos próximos anos: o preço da energia e a questão do licenciamento ambiental. 
Em relação ao preço da energia, tem-se assistido ao longo dos últimos anos a um constante aumento das tarifas de energia (Gráfico 3.3.1), bem acima

\section{Gráfico 3.3.1 - Aumento da tarifa in dustrial média de en ergia elétrica no Brasil}

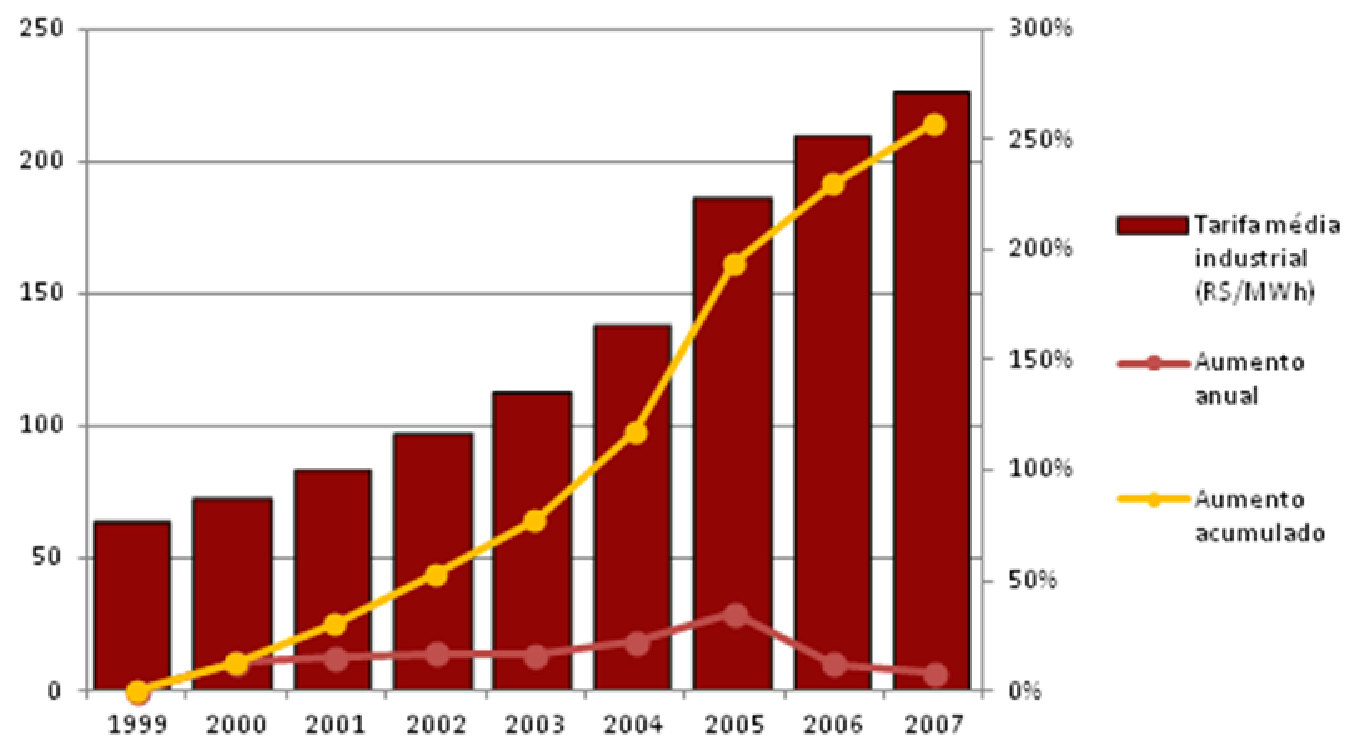

Fonte: ANEEL

da taxa de inflação. Deste modo, a indústria brasileira tende a perder competitividade face a outros países nos quais isto não acontece, tal como se pode observar no Gráfico 3.3.2, no qual os BRIC's surgem destacados.

O lado curioso desta questão é que o que tem vindo a suceder representa exatamente o contrário daquilo que era esperado, visto que se previa um Gráfico 3.3.2 - Tarifa industrial média de energia elétrica em países selecionados ( $\$$ \$MWh)

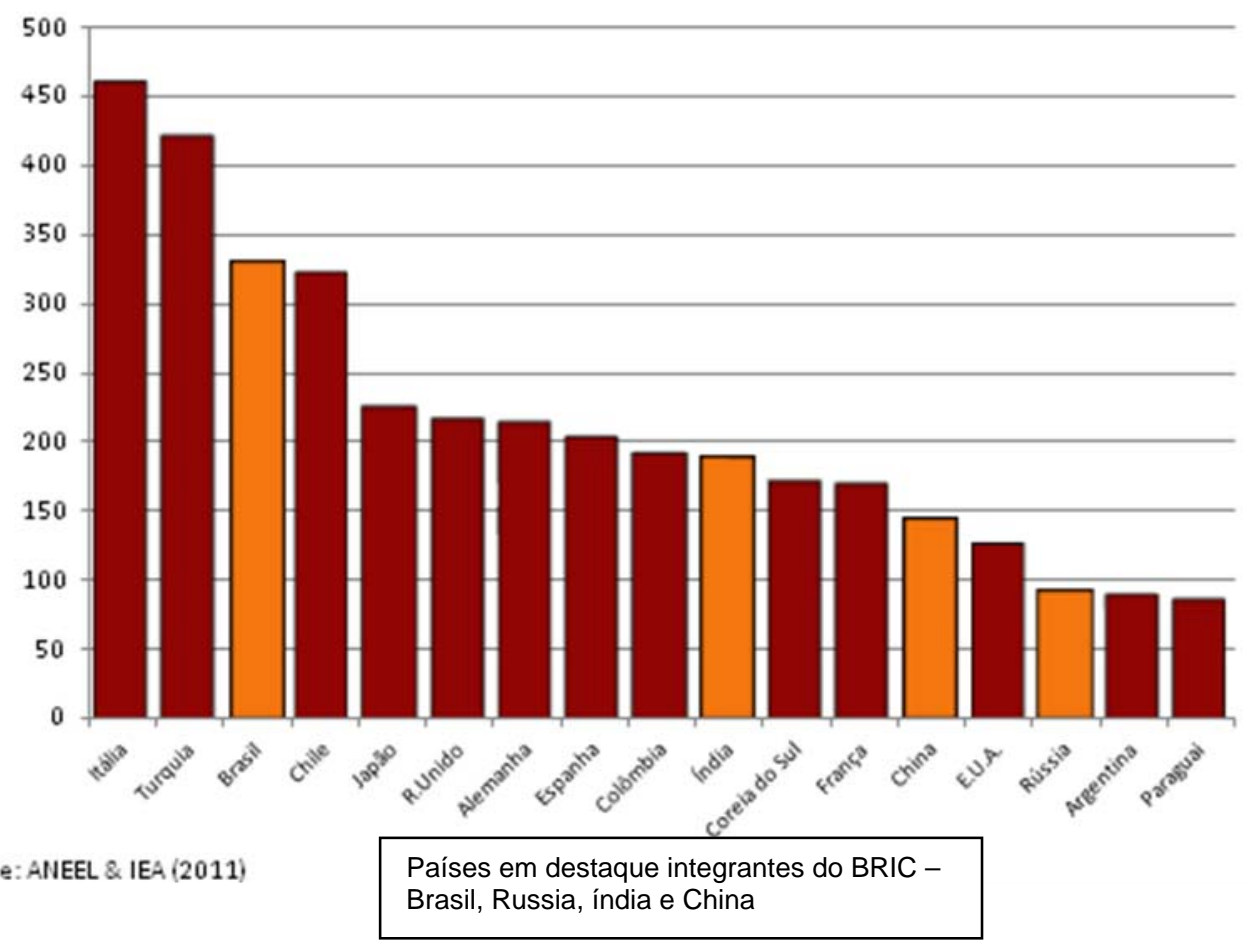


aumento das tarifas nos principais competidores industriais do Brasil dada a enorme dependência dos sistemas de geração de eletricidade destes países por combustíveis fósseis (CNI, 2007). Por outro lado, dada a predominância da geração de tipo hidrelétrico no Brasil, esperava-se uma estabilização das tarifas de energia no país, o que não ocorreu. Este acontecimento serve para sublinhar que, caso não haja ações amplamente dedicadas para resolver os problemas que atualmente o ameaçam, nem a teoricamente favorável estrutura do sistema energético brasileiro poderá por si só assegurar a sua sustentabilidade.

Existem três componentes principais nesta escalada das tarifas de energia (CNI, 2007): encargos, tarifas de transporte nas distribuidoras, e custo de nova capacidade de geração. No que se refere aos dois primeiros fatores, os aumentos deveram-se assim não só à introdução gradual de novos encargos (como o PROINFA, em 2002), como também ao aumento das tarifas de distribuição. Estes são dois fatores que, no entanto, se esperam não contribuir mais para o aumento das tarifas de energia nos próximos anos, pelo que a preocupação se deve focar hoje em dia no aumento dos custos de geração.

Analisando a evolução dos preços médios de geração nos leilões de energia, tanto existente como nova, ao longo dos últimos anos, é possível observar que há um aumento substancial no custo da nova energia hidrelétrica a mais competitiva do país.

Entre os principais motivos para este aumento está, por um lado, o crescimento dos custos relacionados com questões ambientais, e por outro a crescente exigência dos investidores, os quais cada vez requerem prazos de financiamento mais curtos e taxas internas de retorno mais elevadas.

Pode-se assim considerar que este aumento dos custos de geração anulou a vantagem que o Brasil eventualmente poderia ter com o aumento dos preços relacionados com combustíveis fósseis, dos quais as economias competidoras dependem fortemente. 


\subsection{AGENDA PARA ENERGIA ELÉTRICA}

Como forma de enfrentar os já mencionados desafios enfrentados pelo sistema energético nacional e transformá-los em fator de desenvolvimento econômico e de aumento de competitividade, algumas sugestões foram elaboradas na publicação Matriz Energética: Cenários, Oportunidades e Desafios (CNI, 2007). Naturalmente, de modo a se poder estancar a perda de competitividade resultante do aumento dos custos de geração de energia, consideram-se entre estas sugestões aspectos como o risco para os investidores, condições de financiamento, ou simplificação dos processos de licenciamento ambiental. A agenda completa é composta pelos seguintes tópicos:

- Redução dos riscos do investidor;

- Melhora das condições de financiamento;

- Redução de tributos e encargos;

- Valorização da geração hidrelétrica com capacidade de regulação;

- Incentivo à eficiência energética;

- Aperfeiçoamento da lei ambiental;

- Instrumentos para gerência de crises de suprimento.

Considerando o âmbito e os objetivos deste trabalho, destaca-se uma das sugestões em particular: o incentivo à eficiência energética, um tópico que deveria ter sido tratado com a mesma prioridade que o aumento da oferta, tanto no planejamento como nos programas de financiamento. Este argumento é ainda reforçado pelo fato de, em situação de crescimento econômico - como aquele que o Brasil atravessa atualmente - a eficiência energética ter um enorme potencial de contribuir ainda mais para um aumento da competitividade, dada a quantidade de oportunidades que surgem para se projetar e instalar sistemas especialmente otimizados de geração e consumo de energia (CNI, 2007). 


\section{EFICIÊNCIA ENERGÉTICA}

\subsection{INTRODUÇÃO - CONCEITOS FUNDAMENTAIS}

De acordo com o Plano Decenal de Expansão de Energia 2019 (MME \& EPE, 2010), o conceito de eficiência energética é definido como sendo a relação entre um bem produzido ou serviço realizado e a quantidade de energia final utilizada. Quanto mais energia final for utilizada para produzir uma determinada quantidade de um certo bem ou serviço, menos eficiente será essa produção.

Logo, deve ficar bem claro que a eficiência deve ser associada a uma quantidade efetiva de energia final utilizada, não a um mínimo necessário. Além disto, o conceito de eficiência energética pode ser aplicado não só à manufatura de produtos, onde há um bem físico cujo conteúdo energético pode ser claramente delimitado, como também a serviços, na qual se deve considerar a energia requerida para prestação do serviço (MME, 2010).

\subsection{A LEI DE EFICIÊNCIA ENERGÉTICA}

A Lei $n^{\circ} 10.295$, de 17 de outubro de 2001, também conhecida como a Lei de Eficiência Energética ficou no congresso nacional por volta de 10 anos até finalmente ser aprovada e sancionada pelo Presidente da República. A seguir, afim de dar clareza a citada Lei, tem-se a reprodução de seus seis artigos.

Art. $1^{\circ}$ - A Política Nacional de Conservação e Uso Racional de Energia visa a alocação eficiente de recursos e a preservação do meio ambiente.

Art. $2^{\circ}$ - O Poder Executivo estabelecerá níveis máximos de consumo especifico de energia, ou mínimos de eficiência, de máquinas e aparelhos consumidores de energia fabricados ou comercializados no País, com base em indicadores técnicos pertinentes.

$\S 1^{\circ}$ Os níveis a que se refere o caput serão estabelecidos com base em valores técnica e economicamente viáveis, considerando a vida útil das maquinas e aparelhos consumidores de energia.

$\S 2^{\circ}$ Em até 1 (um) ano a partir da publicação destes níveis, será estabelecido um Programa de Metas para sua progressiva evolução. 
Art. $3^{\circ}$ - Os fabricantes e os importadores de máquinas e aparelhos consumidores de energia são obrigados a adotas as medidas necessárias para que sejam obedecidos os níveis máximos de consumo de energia e mínimos de eficiência energética, constantes da regulamentação específica estabelecida para cada tipo de máquina e aparelho.

$\S 1^{\circ}$ Os importadores devem comprovar o atendimento aos níveis máximos de consumo específicos de energia, ou mínimos de eficiência energética, durante o processo de importação.

$\S 2^{\circ}$ As máquinas e aparelhos consumidores de energia contratados no mercado sem as especificações legais, quando da vigência da regulamentação específica, deverão ser recolhidos, no prazo máximo de 30 (trinta) dias, pelos respectivos fabricantes e importadores.

$\S 3^{\circ}$ Findo o prazo fixado no $\S 2^{\circ}$, os fabricantes e importadores estarão sujeitos às multas por unidade, a serem estabelecidas em regulamento, de até $100 \%$ (cem por cento) do preço de venda por eles praticados.

Art. $4^{\circ}$ O Poder Executivo desenvolverá mecanismos que promovam a eficiência energética nas edificações construídas no País.

Art. $5^{\circ}$ Previamente ao estabelecimento dos indicadores de consumo específico de energia, ou de eficiência energética, de que trata esta Lei, deverão ser ouvidas em audiência pública, com divulgação antecipada das propostas, entidades representativas de fabricantes e importadores de máquinas e aparelhos consumidores de energia, projetistas e construtores de edificações, consumidores, instituições de ensino e pesquisa e demais entidades interessadas.

Art. $6^{\circ}$ Esta Lei entra em vigor na data de sua publicação.

Brasília, 17 de outubro de $2001 ; 180^{\circ}$ da Independência e $113^{\circ}$ da República.

Dado a Lei citada, em 19 de dezembro de 2001 através do Decreto 4.059 (BRASIL, 2001b), foi criado o Comitê Gestor de Indicadores e Níveis de Eficiência Energética - CGIEE - constituído dos ministérios MME ( minas e energia), MCT ( ciência e tecnologia) e MDIC ( desenvolvimento, industria e comércio exterior), as agências ANEEL ( Agência Nacional de Energia Elétrica) e ANP ( Agência Nacional do Petróleo). Este comitê, dentre outras atribuições, ficou encarregado da elaboração das regulamentações especificas para cada tipo de aparelho consumidor de energia, o estabelecimento do Programa de Metas com indicação da evolução dos níveis a serem alcançados para cada equipamento regulamentado, a constituição de comitês técnicos para analisar matérias específicas e a deliberação sobre as proposições do grupo técnico para eficientização de energia em edificações. 
Inicialmente, o CGIEE definiu como prioridade os equipamentos já constantes no PBE ( Programa Brasileiro de Etiquetagem) e alguns outros, sobre os quis já existiam estudos desenvolvidos ou apresentavam potencial de economia. A seguir, reproduz-se a sugestão aprovada.

\section{Meta inicial do CGIEE}

\section{Equipamentos Elétricos}

a) CONSTANTES DO PBE:

1. Refrigeradores

2. Combinados

3. Congeladores Verticais

4. Congeladores Horizontais

5. Ar Condicionado Domiciliar

6. Motores Elétricos Trifásicos

7. Transformadores

b) OUTROS:

1. Equipamentos eletrorrurais (desintegrador/picador / moedor)

2.Sistema de iluminação

3. Aquecedores elétricos

Equipamentos que empregam outras fontes de energia

c) CONSTANTES DO PBE:

1. coletores solares

2. fogões a gás

3. aquecedores a gás

d) VEÍCULOS AUTOMOTIVOS

Fonte: CGIEE(2002, p.13) 


\subsubsection{A REGULAÇÃO DE MOTORES E OS ÍNDICES DE EFICIÊNCIA ENERGÉTICA}

Após sua constituição legal, o CGIEE aprovou o Decreto 4.508/2002, que regulamentou a eficiência energética dos motores elétricos trifásicos de indução tipo "rotor gaiola de esquilo" devido a ampla utilização deste tipo de motor no parque nacional em diversos segmentos da indústria, no comércio, em setores residenciais, públicos e agropecuário, em aplicações como bombas, sistemas de ventilação, refrigeração e ar condicionado e máquinas diversas, chegando a representar um consumo de quase um terço da energia elétrica do país.

O Decreto 4.508 estabelece no Art. $3^{\circ}$, que " o indicador de eficiência energética a ser utilizado é o rendimento nominal". A tabela 4.2.2.1 demonstra os valores do rendimentos nominais mínimos estabelecidos pelo Decreto.

\begin{tabular}{|c|c|c|c|c|c|c|c|c|c|}
\hline \multicolumn{10}{|c|}{ Tabela 4.2.2.1 - indicador de Eficiência Energética de Motores } \\
\hline \multirow[b]{3}{*}{$\begin{array}{l}\text { CV OU } \\
\text { HP }\end{array}$} & \multirow[b]{3}{*}{$\mathrm{kW}$} & \multirow{2}{*}{\multicolumn{4}{|c|}{$\frac{\text { PADRÃO }}{\text { PÓLOS }}$}} & \multirow{2}{*}{\multicolumn{4}{|c|}{$\frac{\text { ALTO RENDIMENTO }}{\text { PÓLOS }}$}} \\
\hline & & & & & & & & & \\
\hline & & 2 & 4 & 6 & 8 & 2 & 4 & 6 & 8 \\
\hline 1 & 0,75 & 77 & 78 & 73 & 66 & 80,5 & 80,5 & 80 & 70 \\
\hline 1,5 & 1,1 & 78,5 & 79 & 75 & 73,5 & 82,5 & 81,5 & 77 & 77 \\
\hline 2 & 1,5 & 81 & 81,5 & 77 & 77 & 83,5 & 84 & 83 & 82,5 \\
\hline 3 & 2,2 & 81,5 & 83 & 78,5 & 78 & 85 & 85 & 83 & 84 \\
\hline 4 & 3 & 82,5 & 83 & 81 & 79 & 85 & 86 & 85 & 84,5 \\
\hline 5 & 3,7 & 84,5 & 85 & 83,5 & 80 & 87,5 & 87,5 & 87,5 & 85,5 \\
\hline 6 & 4,5 & 85 & 85,5 & 84 & 82 & 88 & 88,5 & 87,5 & 85,5 \\
\hline 7,5 & 5,5 & 86 & 87 & 85 & 84 & 88,5 & 89,5 & 88 & 85,5 \\
\hline 10 & 7,5 & 87,5 & 87,5 & 86 & 85 & 89,5 & 89,5 & 88,5 & 88,5 \\
\hline 12,5 & 9,2 & 87,5 & 87,5 & 86 & 85 & 89,5 & 90 & 88,5 & 88,5 \\
\hline 15 & 11 & 87,5 & 88,5 & 89 & 88,5 & 90,2 & 91 & 90,2 & 88,5 \\
\hline 20 & 15 & 88,5 & 89,5 & 89,5 & 88,5 & 90,2 & 91 & 90,2 & 89,5 \\
\hline 25 & 18,5 & 89,5 & 90,5 & 90,2 & 88,5 & 91 & 92,4 & 91,7 & 89,5 \\
\hline 30 & 22 & 89,5 & 91 & 91 & 90,2 & 91 & 92,4 & 91,7 & 91 \\
\hline 40 & 30 & 90,2 & 91,7 & 91,7 & 90,2 & 91,7 & 93 & 93 & 91 \\
\hline 50 & 37 & 91,5 & 92,4 & 91,7 & 91 & 92,4 & 93 & 93 & 91,7 \\
\hline 60 & 45 & 91,7 & 93 & 91,7 & 91 & 93 & 93,6 & 93,6 & 91,7 \\
\hline 75 & 55 & 92,4 & 93 & 92,1 & 91,5 & 93 & 94,1 & 93,6 & 93 \\
\hline 100 & 75 & 93 & 93,2 & 93 & 92 & 93,6 & 94,5 & 94,1 & 93 \\
\hline 125 & 90 & 93 & 93,2 & 93 & 92,5 & 94,5 & 94,5 & 94,1 & 93,6 \\
\hline 150 & 110 & 93 & 93,5 & 94,1 & 92,5 & 94,5 & 95 & 95 & 93,6 \\
\hline 175 & 132 & 93,5 & 94,1 & 94,1 & & 94,7 & 95 & 95 & \\
\hline 200 & 150 & 94,1 & 94,5 & 94,1 & & 95 & 95 & 95 & \\
\hline
\end{tabular}


Verifica-se na tabela acima, que os valores de rendimento para os motores de alto rendimento representam um valor considerável em relação aos motores padrão, pois no estabelecimento destes índices, foram estipulados valores que fossem atingidos pelos principais fabricantes na produção de motores, melhorando seus materiais construtivos obtendo-se assim uma melhora considerável no rendimento global do equipamento.

\subsection{MOTIVAÇÃO E BENEFÍCIOS}

De acordo com Schaeffer (2005), são consideráveis os benefícios que podem resultar para o sistema elétrico brasileiro se houver uma aposta dedicada de redução do consumo de energia através de políticas de eficiência energética. De modo a demonstrar isto, é efetuada uma comparação pelo autor entre duas alternativas opostas: a ampliação da capacidade do sistema elétrico nacional e a redução do consumo através de um possível aumento de rendimento dos motores elétricos utilizados proporcionariam.

Deste modo, Schaeffer (2005, p. 73) chega à conclusão que, enquanto que os custos da energia em novas usinas hidrelétricas ou termelétricas a gás natural andariam por volta dos R\$100/MWh no cenário considerado, o custo da energia economizada - através do que se pode denominar de usinas virtuais poderia ser até $45 \%$ menor, para uma taxa de desconto de 12\%. Adicionalmente, há ainda que referir que, relativamente às emissões de carbono evitadas, esta opção representaria uma poupança de cerca de 55.000 toneladas por ano.

O melhoramento dos níveis de eficiência energética ao nível do sistema energético brasileiro teria também um forte impacto junto de consumidores e empresas, que previsivelmente veriam uma redução nos seus encargos energéticos.

Esta redução resultaria não só das medidas de redução do consumo junto dos consumidores (p.ex.: substituição de lâmpadas ou de motores por outros mais eficientes), como também da própria redução das tarifas cobradas pelas concessionárias que, teoricamente, seria uma consequência do decréscimo do custo de geração de energia. 
Para a indústria brasileira, a promoção da eficiência energética apresentase como uma grande oportunidade. Tal como foi referido na seção 3.3, o impacto das elevadas tarifas de energia ao nível da competitividade da indústria é enorme. Assim, torna-se crucial aproveitar a oportunidade que um plano dedicado de eficiência energética pode proporcionar para tornar a economia brasileira mais competitiva.

\subsection{PROMOÇÃO DA EFICIÊNCIA ENERGÉTICA NO BRASIL}

Ao longo da última década, vários programas e ações foram sendo criados de modo a incentivar práticas de eficiência energética na indústria. Em particular, três programas se destacam: PROCEL Indústria, PROESCO, e PEE (MME, 2010).

O programa PROCEL Indústria, ou Programa Nacional de Conservação de Energia Elétrica, teve como principal fator motivador o fato de a força motriz constituir o principal uso final para energia elétrica no setor industrial (MME, 2010). Dentro deste programa, e para abordar especificamente esta questão, foi criado o Projeto de otimização energética de sistemas motrizes, o qual tem dois focos de atuação, através de diversas ações junto à indústria: a promoção de ações para aumentar a taxa de penetração dos motores de alto rendimento no mercado e a minimização das perdas nos sistemas motrizes já instalados. Para este propósito, foram estabelecidos convênios não só com associações e federações industriais, como também com as próprias universidades (MME, 2010).

Como forma de facilitar o investimento em projetos de eficiência energética, foi criada também a linha de crédito do PROESCO - Programa de apoio a projetos de eficiência energética - através da qual o BNDES (Banco Nacional de Desenvolvimento Econômico e Social) financia, direta ou indiretamente, até $80 \%$ do seu valor. Estes projetos podem ir de meros estudos até a compra de máquinas e equipamentos novos, serviços técnicos especializados, ou instalação de sistemas de informação, monitoramento e controle (MME, 2010). 
Em terceiro lugar, a criação do PEE - Programa de Eficiência Energética prevê uma alocação predeterminada de recursos por parte das concessionárias de eletricidade em projetos de eficiência energética - entre $0,25 \%$ e $0,50 \%$ da receita operacional líquida, para as concessionárias e permissionárias cuja energia vendida seja inferior a $1.000 \mathrm{GWh}$ por ano. Estima-se que, de 1999 a 2006, tenham sido investidos por parte das concessionárias de energia cerca de $R \$ 147$ milhões em projetos de eficiência energética na indústria (MME, 2010), representando este valor apenas cerca de $9 \%$ do total de recursos aplicados em outros setores.

Adicionalmente, foi calculado que, ao longo da última década, tenham sido investidos R\$ 161 milhões, distribuídos por 217 projetos de eficiência energética industrial e 13 diferentes setores (CNI, 2009). Com este volume de investimento, é estimado que se tenha alcançado uma economia de $626 \mathrm{GWh}$, sendo o custo médio da energia conservada de cerca de $\mathrm{R} \$ 79 / \mathrm{MWh}$.

Segundo o mesmo estudo, ressalta-se certa predominância de projetos para economia de eletricidade, sendo que cerca de $20 \%$ das ações envolveram troca de motores. Além do mais, de todo o potencial de economia de energia elétrica, a maior parte está concentrada em sistemas motrizes.

\subsection{EFICIÊNCIA ENERGÉTICA E P\&D}

No setor de energia elétrica há inúmeros atores em pesquisa e desenvolvimento, mas, ao contrário do que ocorre na indústria de uso térmico de combustíveis, estes estão, na sua maioria, mais voltados para o utilizador final da energia elétrica do que para o uso desta nas suas próprias empresas (MME, 2010).

Nesta mesma linha de atuação, ao longo dos anos, no sistema energético brasileiro, a grande maioria das inovações em eficiência energética tem sucedido em termos de inovação incremental, através da incorporação de aperfeiçoamentos em tecnologias existentes. Um dos principais fatores para tal é o fato de existirem várias tecnologias que, apesar de amplamente conhecidas e de apresentarem altos níveis de eficiência, ainda não esgotaram todo o seu 
potencial de utilização. No entanto, tal não deve constituir impedimento ao desenvolvimento de soluções inovadoras para a promoção da eficiência energética.

Além do foco em desenvolvimento tecnológico, é referido que a pesquisa em eficiência energética pode - e deve - ter como objeto de estudo formas de gerenciamento de energia, metodologias de medição e verificação, etc. Adicionalmente, as ações de P\&D devem contemplar não só iniciativas de grande porte - as quais podem ser estrategicamente demandadas pelo Governo Federal como forma de transformar o mercado, envolvendo fabricantes de equipamentos, centros de pesquisa, universidades e órgãos governamentais, fazendo uso dos fundos setoriais existentes - como também aquelas de menor porte e baixo investimento.

Uma série de linhas de ações são também propostas na mesma obra, as quais são enumeradas a seguir:

- Definir critérios para o estabelecimento de linhas prioritárias de pesquisa na área de EE, com grande potencial de redução de consumo de energia, a serem contempladas com recursos de fundos setoriais.

- Ampliar o conceito de P\&D para projetos na área de eficiência energética de forma a incluir temas tais como o desenvolvimento de metodologias, gestão de recursos energéticos, etc, para que estes temas possam ser contemplados com recursos financeiros tanto dos fundos setoriais quanto do PEE gerido pela ANEEL.

- Promover o desenvolvimento de metodologias, bases de dados e ferramentas computacionais voltadas para a medição e verificação dos resultados de programas de pesquisa em eficiência energética.

- Estimular e fomentar esforços de P\&D voltados para o desenvolvimento da eficiência energética de equipamentos de uso final, apoiando a iniciativa dos fabricantes, centros de pesquisa e universidades. 
- Alavancar linhas de P\&D focadas em metodologia e tecnologia visando a inserção dos equipamentos industriais no PBE - Programa Brasileiro de Etiquetagem - do INMETRO.

- Coordenar com as agências reguladoras estaduais a aplicação dos recursos das concessionárias de distribuição de gás natural para ações e projetos de eficiência energética, de forma a buscar sinergia nessas atuações.

Das várias linhas de ação propostas, há que se salientar o quarto item, o qual destaca a importância de incentivar e estimular os esforços de P\&D voltados para o desenvolvimento da eficiência energética de equipamentos de uso final, no qual este trabalho se insere. 


\subsection{O MERCADO DE EFICIÊNCIA ENERGÉTICA}

Como parte do mercado de eficiência energética, dois mecanismos principais podem ser considerados (Garcia, 2008):

\section{- Leilão de eficiência energética}

- Certificados brancos

O leilão de eficiência energética é simultaneamente utilizado tanto para expansão do sistema energético - através da criação de usinas virtuais - como também para dinamizar e acelerar a adoção de medidas de eficiência energética. Por seu lado, os certificados brancos inserem-se apenas e necessariamente num contexto em que o cumprimento de determinadas metas físicas de consumo energético é exigido, e a sua negociação apresentaria bastante semelhança com aquela que atualmente se processa com os créditos de carbono.

Como se verá mais adiante na seção 5 , na qual ambos os mecanismos serão abordados com maior detalhe, a conjunção dos dois poderia representar uma alternativa muito interessante para a dinamização e promoção de práticas de eficiência energética no Brasil.

Porém, é importante ressalvar que ambos pressupõem uma confiança absoluta na quantidade de energia reduzida, o que só se pode tornar realidade com um desenvolvido sistema de medição e verificação dos consumos de energia elétrica - algo que não existe ainda. 


\subsection{POTENCIAL DE EFICIÊNCIA ENERGÉTICA NO BRASIL}

O potencial de cada setor depende de suas características tecnológicas, da capacidade de penetração das medidas de EE e dos custos da energia em cada processo (MME, 2010), conforme pode ser observado na Tabela 4.6.1. Em relação ao consumo de energia elétrica, o setor industrial é aquele que apresenta maior potencial (Gráfico 4.6.2), e será analisado com maior detalhe na seção 7 (MME, 2010).

Ainda sobre o potencial de economia de recursos somente com energia elétrica, foi estimado que este possa atingir um valor de quase $R \$ 7$ bilhões por ano, o qual, por sua vez, está fortemente concentrado em sistemas motrizes, equivalendo a cerca de $14 \%$ de todo o potencial (MME \& EPE, 2007).

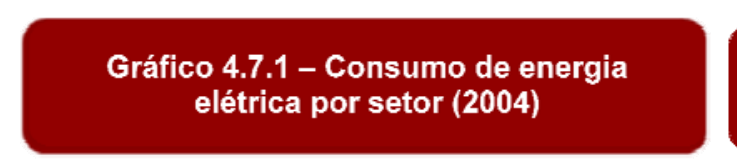

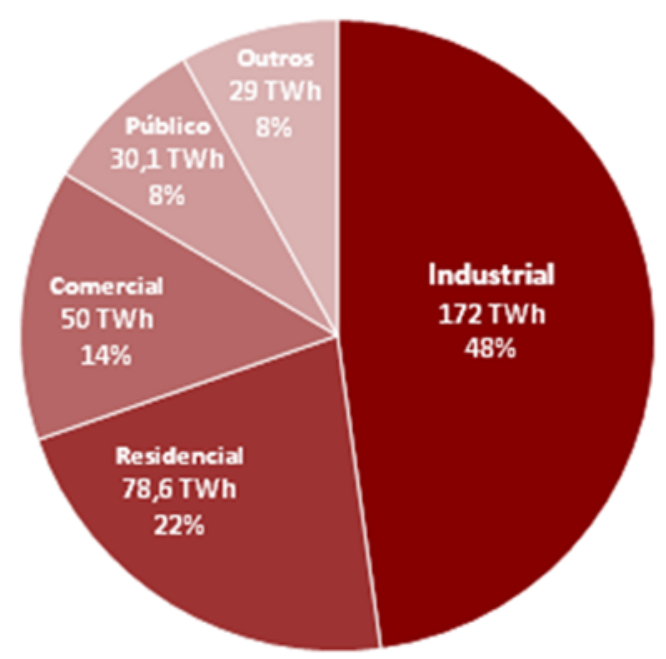

Fonte: EPE (2005)

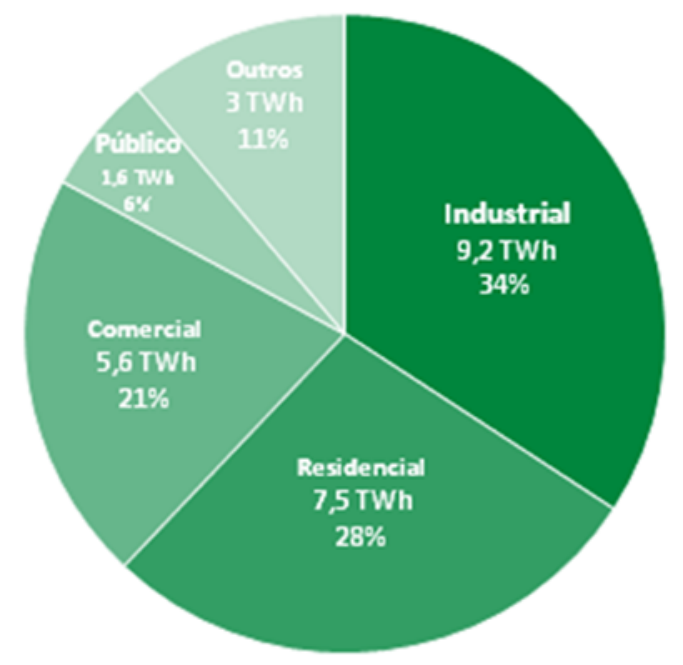

Fonte: EPE (2005)

No entanto, apesar do setor industrial ser o maior consumidor de energia, oferecendo também o maior potencial de eficiência energética, a maioria das ações tem vindo a concentrar-se nos setores residencial e comercial, setores que respondem por cerca de $36 \%$ do total da energia consumida (CNI, 2009). Além do mais, é ainda citado que a economia de energia em ações de eficiência energética no setor industrial potencialmente geraria benefícios para toda a 
sociedade, dado que o custo médio do MWh economizado é, por regra, inferior ao custo marginal de expansão do sistema de energia elétrica.

Essa diferença, além de representar um aumento de competitividade, poderia, idealmente, ser canalizada tanto pelo governo como pelos investidores para outros projetos prioritários.

\begin{tabular}{|c|c|c|c|c|c|c|}
\hline \multirow{2}{*}{$\begin{array}{l}\text { Tabela } \\
\text { Ano }\end{array}$} & \multicolumn{6}{|c|}{$\begin{array}{c}\text { Potencial de conservação de energia elétrica por setor da economia } \\
\text { brasileira (GWh) }\end{array}$} \\
\hline & Total & Residencial & Comercial & Público & Agro pecuário & Industrial \\
\hline 2010 & 2.135 & 548 & 462 & 184 & 95 & 846 \\
\hline 2011 & 4.434 & 1.138 & 960 & 382 & 197 & 1.757 \\
\hline 2012 & 6.964 & 1.787 & 1.508 & 600 & 309 & 2.760 \\
\hline 2013 & 9.747 & 2.501 & 2.111 & 840 & 433 & 3.863 \\
\hline 2014 & 12.802 & 3.285 & 2.773 & 1.103 & 568 & 5.073 \\
\hline 2015 & 16.016 & 4.110 & 3.469 & 1.380 & 711 & 6.347 \\
\hline 2016 & 19.483 & 4.999 & 4.220 & 1.679 & 865 & 7.721 \\
\hline 2017 & 23.215 & 5.957 & 5.028 & 2.000 & 1.030 & 9.200 \\
\hline 2018 & 27.227 & 6.986 & 5.897 & 2.346 & 1.209 & 10.790 \\
\hline 2019 & 31.537 & 8.092 & 6.831 & 2.717 & 1.400 & 12.498 \\
\hline 2020 & 36.097 & 9.644 & 7.643 & 3.057 & 1.474 & 14.281 \\
\hline 2021 & 40.976 & 11.380 & 8.477 & 3.409 & 1.528 & 16.183 \\
\hline 2022 & 46.189 & 13.315 & 9.330 & 3.775 & 1.559 & 18.212 \\
\hline 2023 & 51.756 & 15.466 & 10.203 & 4.153 & 1.563 & 20.372 \\
\hline 2024 & 57.697 & 17.851 & 11.093 & 4.544 & 1.538 & 22.672 \\
\hline 2025 & 64.032 & 20.487 & 12.000 & 4.949 & 1.480 & 25.119 \\
\hline 2026 & 70.784 & 23.394 & 12.921 & 5.366 & 1.385 & 27.720 \\
\hline 2027 & 77.977 & 26.594 & 13.854 & 5.796 & 1.249 & 30.485 \\
\hline 2028 & 85.634 & 30.110 & 14.798 & 6.238 & 1.068 & 33.421 \\
\hline 2029 & 93.783 & 33.965 & 15.749 & 6.693 & 837 & 36.539 \\
\hline 2030 & 102.449 & 38.185 & 16.706 & 7.160 & 551 & 39.847 \\
\hline
\end{tabular}

Fonte: MME (2010)

Ao contrário do que existe em outros países, não existe também uma política governamental de longo prazo especificamente direcionada para o uso eficiente de energia na indústria - fator considerado crucial para uma implementação generalizada de medidas de eficiência energética no setor. 


\subsection{MEDIÇÃO E VERIFICAÇÃO}

De modo a se viabilizar os contratos de desempenho entre ESCOs (empresas de conservação de energia) e proprietários das instalações, nos quais as duas partes chegam a um consenso sobre todos os aspectos que devem ser considerados para o cálculo das economias obtidas, foram desenvolvidas nos anos 80, nos Estados Unidos, as primeiras práticas de medição e verificação $(\mathrm{M} \& \mathrm{~V})$.

Estas práticas tinham o objetivo de assegurar que nenhuma das duas partes fugiria às suas responsabilidades durante a operacionalização do acordo, ou seja, enquanto que a ESCO deve garantir o desempenho dos equipamentos fornecidos, o dono da instalação deve operá-los de modo adequado. Assim, através de medições do desempenho do sistema antes da reforma da instalação, e medições posteriores às alterações contratadas junto da ESCO, torna-se possível determinar o nível efetivo de economia de energia.

Deste modo, para que qualquer plano nacional de eficiência energética venha a ser realmente bem sucedido, é absolutamente fundamental que este possa ser baseado, primeiramente, num sistema de medição e verificação bem implementado e eficaz. Caso isso não aconteça, será mais difícil comprovar os benefícios resultantes de tais ações, e também há o risco de uma possível exploração mal intencionada das mesmas por parte das empresas envolvidas. Por consequência, isto se aplica também no caso da implementação dos leilões de eficiência energética (Garcia, 2008). Neste caso, além do próprio sucesso dos leilões de eficiência energética no Brasil, o qual é inteiramente dependente da adequada implementação de métodos de $M \& V$, haveria a contribuição da consolidação da própria penetração de métodos de M\&V no país.

No entanto, segundo Garcia (2008), de modo a se poder proceder a uma implementação satisfatória, apesar da existência de guias gerais para a definição de processos de M\&V, estas devem ser encaradas acima de tudo como um manual de boas práticas, sendo que não há acordos padrão, ou normas de como se realizar a $M \& V$. Assim, para cada caso, caberá às partes envolvidas a tarefa de elaborar um plano de M\&V otimizado, tendo em conta tanto o volume da economia a se obter, como os custos da diminuição da incerteza da medição, de 
modo que se possa alcançar um bom compromisso entre os custos do processo de $M \& V$ e o grau de incerteza do mesmo.

Idealmente, de um plano de M\&V devem fundamentalmente constar os seguintes pontos (Garcia, 2008):

- Descrição das ações de eficiência energética e resultados esperados;

- Identificação dos limites da determinação das economias;

- Documentação das condições de operação da instalação e dados do consumo-base de energia;

- Auditoria abrangente para determinar com segurança as informações do consumo-base e dados de operação do sistema relevantes para o processo de $\mathrm{M} \& \mathrm{~V}$ :

a) Perfis de consumo de energia e demanda;

b) Tipo de ocupação, densidade e períodos;

c) Condições parciais ou de toda a área da instalação em cada período de operação e estação do ano;

d) Inventário dos equipamentos: dados de placa, localização, condições, fotografias ou vídeos.

e) Práticas de operação do equipamento (horários e regulagens, temperaturas/pressões efetivas);

f) Problemas significativos do equipamento ou perdas.

- Como poderá ser visto mais adiante, a faixa de potencia de motores onde se é possível ter a maior eficiência energética pela utilização de motores de alto rendimento, estão na faixa de potencia de 1cv a $10 \mathrm{cv}$, pois estes motores são encontrados em grande quantidade nos diversos segmentos da indústria, principalmente no ramo de bebidas e alimentos. Dado esta configuração, se torna inviável efetuar a M\&V para cada motor, que seria a forma mais correta de se obter dados confiáveis e precisos. Desta forma, uma saída 
adequada e válida para a solução deste problema, é seguir a orientação do manual de Eficiência Energética da Agencia Nacional de Energia Elétrica (ANEEL), que menciona o Protocolo Internacional para Medição e Verificação de Performance (PIMVP) para a realização da etapa de $M \& V$.

No caso de motores de baixa potencia, dado o grande número em operação e a inexistência de dados confiáveis, o mais adequado e fazer uma estimativa do consumo-base deste tipo de carga de acordo com o perfil de consumo e demanda do local a ser estudado, o tipo de ocupação, densidade e períodos de utilização dos motores e o levantamento energético traçando um perfil em forma gráfica qual a relação entre a carga total do local de estudo em relação aos motores em utilização. Com este perfil de consumo e demanda bem dimensionado, e após as ações de Eficiência Energética, é possível traçar novamente o gráfico do perfil de consumo com base nos dados dos novos motores de alto rendimento, obtendo-se assim uma estimativa de redução, consequência das ações e Eficiência Energética e portanto tornando-se viável a Medição e Verificação para instalações com grandes quantidades de pequenos motores na faixa já citada. Já em locais onde houverem os centros de controle de motores, é possível fazer uma medição centralizada da mesmo forma, traçando um perfil de consumodemanda antes e após as ações de Eficiência Energética. Ressalta-se que não há literaturas dedicadas ao tema e portanto, conforme o Manual de Eficiência Energética cita, o sucesso de um bom processo de M\&V inicia-se com um adequado Plano de Medição e Verificação, dedicado e projetado de acordo com os desafios e informações disponíveis no local em estudo.

\subsection{PRINCIPAIS LIÇÕES DA EXPERIÊNCIA INTERNACIONAL}

De modo a que se possa implementar eficientemente um processo que se traduza numa evolução dos meios de eficiência energética no Brasil, é importante olhar primeiro para o que já foi anteriormente feito em outros países. Assim, não só se torna possível identificar as iniciativas bem sucedidas e com potencial para aplicação no Brasil, como também ajuda a evitar as que não tiveram os 
resultados esperados, assim como prever e/ou evitar erros já cometidos por outros países.

Seguindo esta lógica, uma colaboração entre a CNI, a Eletrobrás e o PROCEL Indústria analisou, em 12 países diferentes, 63 programas de eficiência energética industrial. As conclusões a que se chegou foram as seguintes (CNI, Eletrobrás \& PROCEL, 2009):

- $94 \%$ dos programas associam ganhos de eficiência com ganhos ambientais;

- $82 \%$ possuem algum tipo de incentivo financeiro ou tributário para ações de eficiência energética;

- $62 \%$ são programas voluntários;

- $62 \%$ promovem a substituição de equipamentos e alteração de processos industriais;

- 54 \% disponibilizam informações técnicas.

É ainda referido que quase todos os programas internacionais de eficiência energética industrial foram concebidos por órgãos governamentais em colaboração com associações empresariais. Além do mais, foi ainda observado que, em geral, os setores industriais intensivos em consumo de energia recebem apoio do governo para desenvolver projetos de eficiência energética (CNI, Eletrobrás \& PROCEL, 2010). Entre os principais mecanismos, utilizados internacionalmente, para incentivo à eficiência energética na indústria, estão as seguintes medidas, algumas das quais já em parte presentes no Brasil (CNI, Eletrobrás \& PROCEL, 2010):

- Reduções tributárias vinculadas a projetos industriais de eficiência energética;

- Divulgação de informações técnicas, econômicas e financeiras sobre equipamentos e processos industriais eficientes;

- Capacitação de pessoal em medidas de conservação de energia na indústria; 
- Custeio, total ou parcial, de diagnósticos energéticos e estudos de otimização energética de instalações industriais;

- Incentivos fiscais e creditícios para equipamentos industriais eficientes;

- Padrões mínimos obrigatórios de eficiência energética para alguns equipamentos de uso geral na indústria;

- Imposição de metas de conservação de energia para supridores de energia, ou para concessionárias de serviços públicos de energia, com processos envolvendo medição e verificação;

- Fomento à participação de ESCOs em contratos de desempenho em programas de eficiência energética na indústria;

- Acordos voluntários entre governo e associações patronais na implementação de programas de eficiência energética na indústria, sobretudo em segmentos energo-intensivos;

- Financiamento de projetos de pesquisa e desenvolvimento sobre equipamentos e processos industriais eficientes;

- Adoção de normas de gestão otimizada de energia na indústria, compatíveis com a ISO 9000 e a ISO 14000.

Entre os principais mecanismos, utilizados internacionalmente, para incentivo à eficiência energética na indústria, as que foram consideradas mais promissoras para aplicação no Brasil foram as seguintes (CNI, Eletrobrás \& PROCEL, 2010):

- Associação de ações de eficiência energética a ganhos ambientais, em especial, a reduções das emissões de gases de efeito estufa;

- Priorização do setor industrial nos programas governamentais de eficiência energética;

- Aproximação entre indústria e governo na construção de programas de eficiência energética; 
- Estruturação e difusão de uma sólida base de dados que permita maior segurança nas decisões sobre projetos de eficiência energética;

- Fomento à realização de diagnósticos energéticos de instalações industriais;

- Apoio a contratos de desempenho com ESCOs em programas de eficiência energética industrial;

- Estímulo a parcerias público-privadas para pesquisa e desenvolvimento (P\&D) de equipamentos e processos industriais eficientes;

- Normas ISO para consumo de energia;

- Revisão das metodologias de medição e verificação de resultados de projetos de eficiência energética.

Ao analisar os mecanismos listados, é possível verificar como o âmbito deste trabalho pretende englobar várias destas medidas consideradas como mais promissoras para aplicação no Brasil. De fato, a implementação de leilões de eficiência energética garantidamente permitiria uma priorização do setor industrial, assim como potenciaria o incentivo a programas governamentais de eficiência energética de apoio a contratos de desempenho com ESCOs. Adicionalmente, a criação do leilão teria como consequência necessária um grande desenvolvimento do sistema e metodologias de medição e verificação, como se irá analisar na seção 5 . 


\section{LEILÃO DE EFICIÊNCIA ENERGÉTICA}

\subsection{DESCRIÇÃO}

O conceito de leilão de eficiência energética pressupõe que qualquer entidade, ao investir em medidas de eficiência energética, tenha a possibilidade de vender a energia que passou a economizar através dessas mesmas medidas. Deste modo, pode-se também considerar que, à aplicação de uma certa medida de eficiência energética, corresponde a criação de uma usina virtual de capacidade igual à energia economizada através dessa mesma medida.

Os vendedores no leilão poderiam ser as ESCOs, os próprios consumidores, ou até empresas que produzam bens de consumo, as quais teriam a oportunidade de captar dinheiro para investir em inovação, de modo a fabricar produtos mais eficientes. Deste modo, o leilão poderia constituir uma fonte de renda adicional para indústrias que investissem na redução do consumo energético.

Conforme Garcia (2008), o leilão se processaria através de quatro diferentes fases: requisição de propostas, implantação de medidas de eficiência energética, seleção através de leilão, e pagamento contra energia economizada. Esta metodologia, pode ser aplicada desde que exista metas de reduções de consumo de energia obrigatória estipuladas pelo governo afim de otimizar o consumo a longo prazo.

Apesar de ser um conceito recente, o leilão de eficiência energética justifica ser considerado seriamente nos dias de hoje, sobretudo devido a três questões principais:

- A expansão do sistema elétrico e o planejamento energético;

- A questão ambiental;

- A efetividade das ações de eficiência energética.

O Brasil atravessa atualmente uma fase de constante crescimento econômico, exigindo, portanto, um adequado plano de expansão do sistema 
energético de modo a que se possa suprir o acréscimo na demanda. Todavia, a expansão prevista prevê custos cada vez mais altos de geração de eletricidade e é exatamente por este lado que se deve abordar a primeira questão, visto que o leilão de eficiência energética permitiria a rápida expansão de usinas virtuais, cujo custo por MWh poderia ser uma alternativa a expansão física. Segundo Garcia (2008), existe no Brasil um grande potencial de eficiência energética a custo menor que a expansão, no qual a energia elétrica consumida por motores tem uma expressão significativa.

Apesar das suas vantagens, não se deve entender as usinas virtuais como forma de substituição das usinas físicas. No entanto, há que se destacar que o aumento da capacidade total de usinas virtuais, através de um crescimento dos investimentos em projetos de eficiência energética - fomentado, por exemplo, através do leilão de eficiência energética - seria assim um complemento ideal para a expansão física prevista para o sistema energético nacional. Obter-se-ia assim uma redução do custo médio do MWh gerado, o qual se traduziria necessariamente num aumento de competitividade da indústria brasileira face às suas concorrentes internacionais.

No que se refere à questão ambiental, o leilão de eficiência energética também apresenta um enorme potencial ao contribuir para a criação de usinas virtuais, cujas emissões, naturalmente, são nulas. Tendo em conta os protocolos estabelecidos internacionalmente, assim como as metas que o país terá de cumprir, o potencial deste tipo de leilão é grande, até porque levaria o país e a própria indústria a atingirem mais facilmente os objetivos propostos no protocolo de Kyoto.

Por fim, relativamente à efetividade das ações de eficiência energética, ressalta-se que, juntamente com a introdução e implementação do leilão de eficiência energética, sempre viria associado um desenvolvimento da estrutura de $M \& V$ no país. Tendo em conta que a estrutura de $M \& V$ atualmente existente é bastante deficitária, não permitindo a correta avaliação dos resultados efetivos obtidos em projetos de eficiência energética, a introdução do leilão representaria um importante passo nesta direção, não só para a indústria como para o próprio país. 
É importante destacar e avaliar sob a ótica de análise simples da expansão do sistema energético, fazendo aqui algumas considerações como:

1- O sistema de $M \& V$ seja adequado para o projeto em questão

2- O Leilão de Eficiência Energética se torne realidade operacional

3- A necessidade de expansão do sistema

Visto que o consumo de energia elétrica tende a crescer juntamente com o crescimento do país, pode-se dizer que caso o custo evitado com as ações de eficiência energética somados ao valor do leilão agregando valor a este, tenham, de forma simples, custo inferior ao da expansão do sistema, justifica-se a implantação da sistemática proposta neste trabalho, que é promover a eficiência energética com geração de valor agregado com os leilões destes. Para tal, partiuse do ponto conforme decreto citado na lei de Eficiência Energética, onde os motores elétricos foram os primeiros a ter índices de eficiência conforme pode ser visto na tabela 4.2.2.1.

Duas sistemáticas são propostas:

1- Considerando que já houvessem metas definidas e resoluções a respeito obrigando a redução do consumo através de medias de Eficiência Energética, onde a economia seria vendida e o investimento inicial para as ações de EE seriam a custo do empreendedor e;

2- Incentivo governamental, que fomentaria as ações de Eficiência Energética através de reduções da carga tributária, financiamentos a juros baixos e financiamento facilitado ou até mesmo por entidades particulares como as ESCO's, que investiriam no projeto, implementariam e, após conclusão e verificação da economia gerada, seriam remunerados por parte da economia gerada pelo empresário ou proprietário do estabelecimento onde foi feito o projeto.

Não se trata aqui quem seria o provedor de recursos financeiros para tal, porém, seria de bom tom que esta iniciativa partisse do órgãos governamentais e estes sistemas fossem testados de forma experimental em instituições públicas, 
afim de promover uma regulamentação e estabelecer um cronograma de cumprimento de metas para otimizar os custos com o insumo energia elétrica. 


\subsection{PARTICIPANTES}

Como já foi referido na seção 5.1, os principais participantes no leilão de eficiência energética no Brasil seriam as ESCOs, os consumidores ou fabricantes de bens de consumo. No entanto, segundo Garcia (2008) ao mencionar que, nos projetos de eficiência energética implementados através de Demand-Side Bidding (DSB) nos EUA, 87\% da energia economizada foi obtido através das ESCOs, é muito provável que venha a ser este o mercado principal a participar dos leilões de eficiência no Brasil.

Apesar deste fato, o mesmo autor refere que os grandes consumidores também terão uma participação importante, participando assim com os seus próprios projetos de redução do seu consumo energético. Também é dado como certo que os fabricantes de certos equipamentos entrarão com propostas pela venda da energia a ser economizada através da introdução de tecnologia mais eficiente - como no caso dos motores de indução trifásicos, como proposto por Garcia (2008).

\subsection{CERTIFICADOS BRANCOS}

Os certificados brancos são documentos que certificam que uma certa quantidade de energia foi economizada e são geralmente um instrumento utilizado como complemento à implementação de metas físicas de redução de consumo energético a companhias de energia ou indústrias. De acordo com Schaeffer (2005), este tipo de certificado poderia ser introduzido não só de forma a conduzir a metas específicas de redução de consumo, como também de modo a fortalecer o próprio leilão de eficiência energética. Mais do que uma alternativa, seria assim um catalisador do leilão, o qual, por sua vez, viria a funcionar como forma de complementar o cumprimento das metas dos certificados brancos.

O seu funcionamento é bastante semelhante aos dos certificados de carbono e contribui para a criação de um mercado de certificados junto das empresas que não conseguem cumprir totalmente as suas metas. Segundo Schaeffer (2005), a ideia seria introduzir os certificados brancos como forma de substituir pouco a pouco o PEE. Deste modo, ocorreria uma substituição de 
metas financeiras por metas físicas, as quais, na opinião do autor, têm uma eficácia bem superior para o propósito que se pretende - reduzir o consumo através de um aumento geral de eficiência energética. Caso as suas metas não fossem cumpridas, a empresa teria de pagar multa, ou - e é aqui que os certificados brancos se encaixam na perfeição - simplesmente adquirir em leilão de eficiência energética o equivalente à energia que deveria ter poupado.

No caso da implementação de um sistema de certificados brancos e de leilão de eficiência energética no Brasil, a seguinte proposta foi elaborada por Schaeffer (2005), aproveitando o fato de o Brasil ser um dos países líderes no que tange o MDL (Mecanismo de Desenvolvimento Limpo) implementado pelo protocolo de Kyoto:

- Criação de certificados brancos com metas anuais de redução de consumo específico de 1-3\%/ano para todos os agentes ao longo dos próximos 5-10 anos;

- Leilões de eficiência energética seriam adicionais às metas obrigatórias, e os valores leiloados seriam debitados das metas obrigatórias do vendedor no ano seguinte ou seguintes, dependendo dos montantes vendidos;

- Mecanismo estimularia a aceleração do cumprimento das metas físicas individuais através da remuneração advinda do leilão, no caso do mercado de certificados brancos não se mostrar líquido e/ou grande o bastante para absorver o potencial realizado;

- Há que se estudar melhor as implicações da competição que poderá advir do comércio de certificados brancos (se houver déficit de certificados no mercado) e os leilões de eficiência energética; 


\section{MOTORES ELÉTRICOS}

\subsection{O MOTOR ELÉTRICO}

Um motor elétrico é uma máquina destinada a transformar energia elétrica em energia mecânica. Por combinar as vantagens da energia elétrica - baixo custo, facilidade de transporte, limpeza e simplicidade de comando - com uma construção relativamente simples, custo reduzido, grande versatilidade de adaptação às cargas dos mais diversos tipos e melhores rendimentos, acabou por se tornar o mais usado de mecanismo para operação de máquinas de diferentes tipos e tamanhos para diversos tipos de cargas em seus usos finais.

\subsection{MERCADO DE MOTORES ELÉTRICOS NO BRASIL}

Visto que não foram encontradas fontes de qualidade mais recentes no que se refere ao mercado de produção e venda de motores elétricos no Brasil, foram utilizadas como base para o trabalho as considerações efetuadas por Schaeffer (2005) acerca da composição do mercado em 2005. De acordo com o autor, o mercado de motores elétricos em 2005 no Brasil era composto por quatro empresas:

- Weg - detinha cerca de $80 \%$ do mercado, principalmente em motores industriais;

- Eberle - com participação no mercado de cerca de 10\%;

- Kohlbach-Siemens - cerca de $8 \%$ do mercado de motores trifásicos, dispondo de uma linha até $150 \mathrm{cv}$, com ênfase nos motores até $30 \mathrm{cv}$;

- SEW - empresa de origem alemã, não se dispondo de informações referentes à sua quota de mercado.

Deste modo, pode-se considerar que, em 2005, o mercado de motores no Brasil era dominado pelos fabricantes nacionais, os quais detinham ao que tudo indica, acima de $90 \%$ do mercado, embora não haja dados de grande precisão 
disponíveis. Há que se ressaltar, no entanto, que ainda se encontram em funcionamento motores de outras marcas (p.ex.: Búfalo) que já não são mais fabricados.

Também ocorre a entrada de motores estrangeiros, embora em pequena porcentagem, sobretudo através de equipamentos montados por OEMs (Original Equipment Manufacturers), nos quais, segundo Schaeffer (2005), há de se destacar os setores de beneficiamento de madeira (móveis etc.) e indústria mecânica.

Atualmente, é possível que motores de marcas estrangeiras como $A B B$ ou GE tenham também quotas de mercado significativas, mas não foi possível obter dados relativos às mesmas.

\subsection{TIPOS DE MOTORES MAIS COMUNS}

Diversos tipos de motores elétricos existem atualmente. No entanto, os motores elétricos mais comumente utilizados são os seguintes:

- Motores de corrente contínua - Têm um custo elevado de fabricação e de manutenção. Ademais, necessitam de uma fonte de corrente contínua ou de um dispositivo que possa converter corrente alternada comum em corrente contínua. Oferecem a possibilidade de funcionar com velocidades ajustáveis entre limites bastante amplos, sendo que, por essa razão, são indicados para casos em que haja necessidade de grande flexibilidade e/ou precisão. Por esta razão, o seu uso restringe-se, sobretudo, a casos especiais em que estas exigências compensam o elevado custo de instalação, ou simplesmente pelo fato de a alimentação usada ser contínua (Eletrobrás, 2000).

- Motores de corrente alternada - Como a distribuição de energia elétrica é feita geralmente em corrente alternada, este tipo de motores acaba por ser o mais utilizado. O seu princípio de funcionamento baseia-se no campo girante, o qual surge quando um sistema de correntes alternadas trifásico é aplicado em pólos defasados fisicamente de $120^{\circ}$. 
Dentro dos motores de corrente alternada, os principais tipos são o motor síncrono e o motor de indução.

\subsection{A IMPORTÂNCIA DO MOTOR DE INDUÇÃO TRIFÁSICO DE} GAIOLA

Conforme o Guia Operacional de Motores Elétricos (Eletrobrás, 2000), o motor de indução trifásico representa a maior parte do mercado de motores elétricos, sobretudo devido a uma série de vantagens significativas sobre o motor de corrente contínua. Algumas destas vantagens são (Eletrobrás, 2000):

- Comparativamente com um motor de corrente contínua de mesma potência, o custo de um motor de indução trifásico é muito menor;

- A manutenção do motor de indução trifásico é mais simples e bem menos onerosa;

- O motor de indução trifásico consome menos energia nos processos de aceleração e frenagem;

- Com o motor de indução trifásico velocidades maiores podem ser atingidas.

A desvantagem do motor de indução é a limitação da faixa de variação de velocidade do motor quando controlado por variação da tensão do estator.

Atualmente, devido à evolução de sistemas eletrônicos que permitem o controle do motor por variação simultânea da tensão e frequência, esta desvantagem tem se tornado cada vez menos relevante.

Pelo exposto, o motor de indução trifásico, com as suas inúmeras vantagens sobre o motor de corrente contínua, é de longe o mais utilizado no parque industrial brasileiro. 


\subsection{MOTORES ELÉTRICOS E EFICIÊNCIA ENERGÉTICA NA INDÚSTRIA}

O perfil de consumo de eletricidade na indústria brasileira, por setor e uso final, é apresentado na Tabela 6.5.1 (MME, 2007).

Observa-se que quase $70 \%$ da energia passa por motores elétricos, reunindo-se os usos finais como força motriz e refrigeração. Torna-se evidente, portanto, a relevância que os motores elétricos assumem no consumo de eletricidade por parte da indústria.

Deste modo, numa perspectiva de melhoria de eficiência energética no

\section{Tabela 6.5.1 - Particip ação da força motriz no consumo elétrico da indústria (2005)}

\begin{tabular}{|c|c|c|c|}
\hline \multirow{2}{*}{ Setor } & Total & \multicolumn{2}{|c|}{ Força Motrize Refrigeração } \\
\cline { 2 - 4 } & $(\mathrm{GWh} / \mathrm{a})$ & $(\mathrm{GWh} / \mathrm{a})$ & $\%$ \\
\hline Cimento & 3.754 & 3.702 & $99 \%$ \\
\hline Ferro-gusa e aço & 16.880 & 14.111 & $84 \%$ \\
\hline Ferro-ligas & 7.650 & 236 & $3 \%$ \\
\hline Mineração e pelotização & 9.202 & 8.586 & $93 \%$ \\
\hline Não ferrosos & 33.907 & 10.282 & $30 \%$ \\
\hline Química & 21.612 & 16.465 & $76 \%$ \\
\hline Alimentose bebidas & 19.851 & 16.009 & $81 \%$ \\
\hline Têxtil & 7.776 & 7.582 & $98 \%$ \\
\hline Papel e celulose & 14.098 & 13.442 & $95 \%$ \\
\hline Cerâmica & 3.050 & 2.745 & $90 \%$ \\
\hline Outros & 34.173 & 23.750 & $69 \%$ \\
\hline Total & 172.061 & 116.909 & $68 \%$ \\
\hline
\end{tabular}

Fonte: MME \& EPE (2007)

setor industrial - o setor da economia que mais eletricidade consome anualmente no Brasil - torna-se fundamental analisar as ações que podem ser levadas a cabo para tal. As medidas de eficiência energética que normalmente são consideradas são a adequação da potência do motor à carga, o uso de acionadores, e o uso de motores de alto rendimento (MME \& EPE, 2007), no qual se enquadra o tema deste trabalho. O setor de ferro ligas onde se destaca um percentual baixo em relação aos demais, refere-se apenas ao consumo destinado apenas a força motriz e refrigeração. A grande parte da energia 
consumida está em seu manuseio onde este uso final não se insere e por isso este valor fica baixo em relação aos demais. 


\subsubsection{SELEÇÃO DA POTÊNCIA DO MOTOR}

Conforme é referido por Augusto Júnior (2001), a adequação da potência nominal para o acionamento de uma carga é extremamente importante na aplicação de motores. De modo que se possa ter uma compreensão rápida deste fato, tomar-se-á agora o exemplo dado pelo mesmo autor para exemplificar este assunto. Considere-se assim um motor industrial de $100 \mathrm{CV}, 4$ pólos, categoria $\mathrm{N}$, linha Standard, fabricante Weg, e que acione uma carga constante que requer $25 \mathrm{CV}$ apenas (rendimento de $81,1 \%$ com $25 \%$ de carga).

Tabela 6.5.1.1 - Economia obtida através do correto dimensionamento do motor

\begin{tabular}{|c|c|c|}
\hline Parâmetro operacional & Motor em uso & $\begin{array}{c}\text { Motor corretamente } \\
\text { dimensionado }\end{array}$ \\
\hline Potência (CV) & 100 & 25 \\
\hline Carga & $25 \%$ & $100 \%$ \\
\hline Rendimento & $81,1 \%$ & $90,1 \%$ \\
\hline Tempo de operação anual (h) & 2500 & 2500 \\
\hline Consumo $(\mathbf{k W h})$ & $56.681,57$ & $51.019,70$ \\
\hline Economia anual $(\mathbf{k W h})$ & & $5.661,87$ \\
\hline
\end{tabular}

Fonte: Elaboração própria, com base em Augusto Júnior (2001)

Ao se substituir este motor por um de potência nominal de 25 CV (90,1\% de rendimento com 100\% de carga), conforme apresentado na Tabela 6.5.1.1, não só se consegue poupar cerca de 6000 kWh num ano, como se consegue o retorno do investimento em apenas 11 meses.

Deste modo, torna-se evidente a importância de se proceder a uma correta seleção do motor elétrico, não só pela poupança em termos financeiros, como pelo próprio gasto desnecessário de energia e inevitáveis impactos no ambiente a que esta conduz.

Para auxiliar no processo de correta seleção de um motor elétrico, existem programas computacionais criados especialmente para esse propósito. Um bom exemplo é o BDMotor (Eletrobrás, 2008), o qual permite a seleção de um motor através da medição dos seguintes parâmetros: 
- Corrente média de linha;

- Velocidade do eixo;

- Potência trifásica de entrada (kW).

Tabela 6.5.1.2 - Critérios mais frequentes para dimensionamento de motores

\begin{tabular}{|l|ccccc|}
\hline Dimensionamento/substituição processa-se com base em: & Sempre & $\begin{array}{c}\text { Quase } \\
\text { sempre }\end{array}$ & Ocasionalm. & Nunca & $\begin{array}{c}\text { Sem } \\
\text { resposta }\end{array}$ \\
\hline Potência do motor a substituir (substituição por igual) & $55 \%$ & $31 \%$ & $4 \%$ & $0 \%$ & $11 \%$ \\
\hline Motor em estoque mais próximo (em potência) do motor a substituir & $5 \%$ & $10 \%$ & $20 \%$ & $41 \%$ & $24 \%$ \\
\hline Medições ou estimativas da carga ideal necessária & $7 \%$ & $3 \%$ & $12 \%$ & $55 \%$ & $23 \%$ \\
\hline Especificações do equipamento de produção & $24 \%$ & $20 \%$ & $8 \%$ & $25 \%$ & $23 \%$ \\
\hline
\end{tabular}

Fonte: U.S. Department of Energy (1998)

Na Tabela 6.5.1.2 apresentam-se os vários critérios mais frequentemente utilizados no processo de seleção de um motor. Como se pode observar, raramente são levados em conta procedimentos que favoreçam a otimização do processo, o que tem como resultado, inevitavelmente, que a escolha final do motor não seja a ideal, com as consequentes perdas de eficiência energética, assim como financeira, que daí advém.

Os critérios mais frequentemente utilizados para uma adequada seleção do motor elétrico são os seguintes (Augusto Júnior, 2005):

- Potência eficaz;

- Conjugado máximo motor;

- Conjugados nominal e de partida;

- Tempo de aceleração;

- Potência disponível. 


\subsubsection{MOTORES DE ALTO RENDIMENTO}

Os motores de alto rendimento são, em geral, mais caros que os motores standard ou motores normais de linha, mas podem apresentar vantagens significativas em diversos casos, devido ao seu rendimento superior. A norma brasileira NBR 7094 (Schaeffer, 2005) estabelece os níveis mínimos de rendimento que devem ser apresentados por qualquer motor designado como de alto rendimento pelo fabricante.

Os motores de alto rendimento são projetados tendo em conta a maximização do seu rendimento sem aumentar desmesuradamente o custo de fabricação. Para tal, é feita uma otimização tanto do processo de dimensionamento como da escolha e aplicação de todos os materiais empregados na sua fabricação, de modo a minimizar as perdas de energia que ocorrem durante a operação do motor.

Como resultado deste processo de otimização, os motores de alto rendimento costumam operar a uma temperatura mais baixa, resultando numa vida útil maior dos mesmos. Além do mais, apresentam uma menor necessidade de manutenção e também um menor nível de ruído devido ao melhor balanceamento e menores tolerâncias de fabricação. Apesar de tudo, estas características variam de fabricante para fabricante, sendo que cada um adota medidas ligeiramente diferentes para elevar o rendimento dos seus motores.

Há que se salientar, porém, que, dependendo de certos fatores que serão analisados na seção seguinte, nem sempre se justifica o investimento num motor de alto rendimento. Além do mais, este aumento do rendimento em relação aos motores normais varia com a potência do motor e com o fabricante - não é um valor constante. Em geral, o acréscimo de rendimento diminui com o aumento da potência nominal. No entanto, há que se levar sempre em consideração o valor absoluto da diferença das perdas entre um motor normal e um de alto rendimento. De fato, para motores de elevada potência, até a menor diferença no rendimento pode representar uma redução significativa no consumo do motor em kWh. 
As principais alterações que costumam constar num motor de alto rendimento são as seguintes:

a) Chapas Magnéticas: As chapas que compõem o rotor e o estator são de melhor qualidade, obtendo-se perdas por histerese e por correntes induzidas bem menores que aquelas com as chapas utilizadas nos motores standard. Outras alterações nas chapas podem também incluir redução da espessura e/ou tratamento térmico para a redução de perdas.

b) Enrolamentos do Rotor e do Estator: Os enrolamentos de cobre do estator e de alumínio do rotor possuem um volume maior de material, levando a resistências elétricas menores, contribuindo assim para reduzir as perdas por efeito Joule. Alguns fabricantes também utilizam materiais com menor resistividade.

c) Ventilador: São otimizados de forma a ter uma maior eficiência, reduzindo as perdas por ventilação. Uma vez que o motor possui menos perdas, a necessidade de ventilação também diminui, levando a uma redução da potência necessária para o ventilador.

d) Rolamentos: São empregados rolamentos especiais com um menor coeficiente de atrito, aumentando assim a sua vida útil.

e) Dimensões Principais: O diâmetro do rotor, as ranhuras, o entreferro e o comprimento axial do motor são dimensionados especificamente para maximizar o rendimento do motor.

f) Tolerâncias Mecânicas Menores: Ao utilizarem-se ferramentas de maior precisão, consegue-se diminuir as tolerâncias de fabricação e, desta forma, obtém-se um melhor balanceamento geral do motor e um decréscimo na quantidade de imperfeições, as quais têm uma contribuição significativa para as perdas adicionais. Assim, máquinas com entreferros menores podem ser fabricadas, necessitando de menores correntes de magnetização e melhor fator de potência e rendimento. Menores tolerâncias também resultam em menos ruído e vibração. 
No Gráfico 6.5.2.1 podem-se verificar tanto as diferenças de rendimento Gráfico 6.5.2.1 - Diferenç as de rendimento (\%) e de preço ( $R \$)$ entre motores standard $\mathrm{e}$ motores de alto rendimento por potência e $n^{\circ}$ de pólos

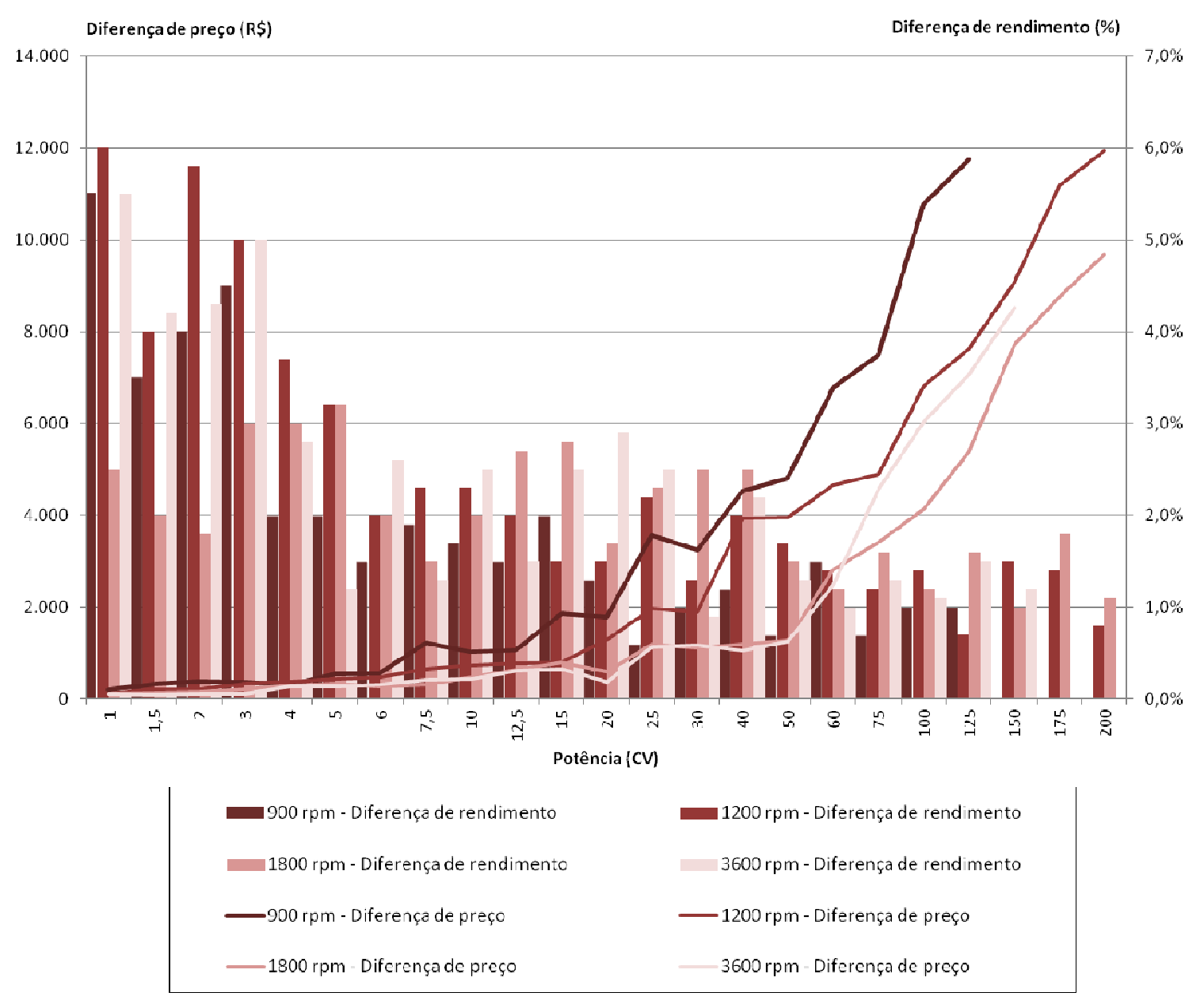

3como as diferenças de preço (BDMotor, 2008) entre motores standard e motores de alto rendimento da mesma potência, de acordo com o número de pólos. É possível constatar que, em geral, quanto menor a potência do motor, maior é a diferença de rendimento entre motores standard e motores de alto rendimento. Relativamente aos preços, ocorre exatamente o oposto - quanto maior a potência, maior será a diferença de preço. 


\subsubsection{MERCADO PARA MOTORES DE ALTO RENDIMENTO}

De forma a se poder determinar qual a potencial dimensão do mercado para motores de alto rendimento, convém primeiro entender o modo como o mercado de motores elétricos brasileiro está estruturado, até porque há vários segmentos no mercado de motores elétricos em que a introdução de motores de alto rendimento não se justifica. Além do mais, é necessário entender que há dois processos diferentes através dos quais um motor de alto rendimento pode ser instalado, conforme pode ser observado no Gráfico 6.5.2.1.2:

Substituição - tanto pode acontecer em casos de chegada ao final da vida útil de um motor (p.ex.: por avaria) como em casos de mera necessidade de um maior rendimento, com as poupanças energéticas e financeiras necessariamente associadas. Deve-se ainda ter bem presente que nem em todas as situações se justifica proceder à substituição do motor standard (p.ex.: quando o tempo médio de operação é baixo).

- Primeiras compras (nova instalação) - em casos de construção de novas instalações industriais, ou apenas de expansão de instalações já existentes.

Gráfico 6.5.2.1.1 - Definição do mercado para motores de alto rendimento

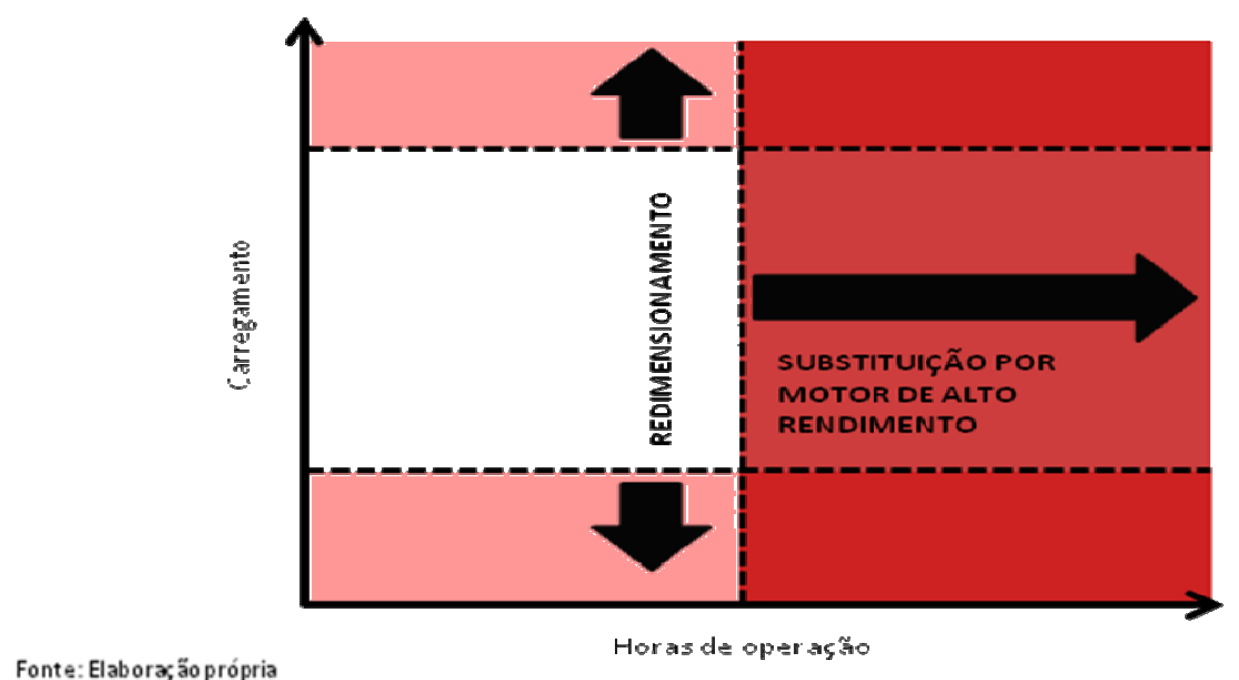


Na seção 7 pretende-se estudar mais pormenorizadamente a potencial dimensão deste mercado na indústria, através dos vários setores que a compõem. No Gráfico 6.5.2.1.1, incluem-se também os casos em que se justifica redimensionar um motor (i.e. quando há sobre ou sub-dimensionamento de um motor), pois podem representar uma oportunidade extra para a introdução de motores de alto rendimento. De fato, existem casos em que a substituição do motor em funcionamento por outro de alto rendimento com potência igual não se justifica economicamente, mas em que a escolha de um motor de alto rendimento passa a fazer sentido quando inserida num processo de redimensionamento.

Gráfico 6.5.2.1.2 - Segmentação no mercado de motores de alto rendimento

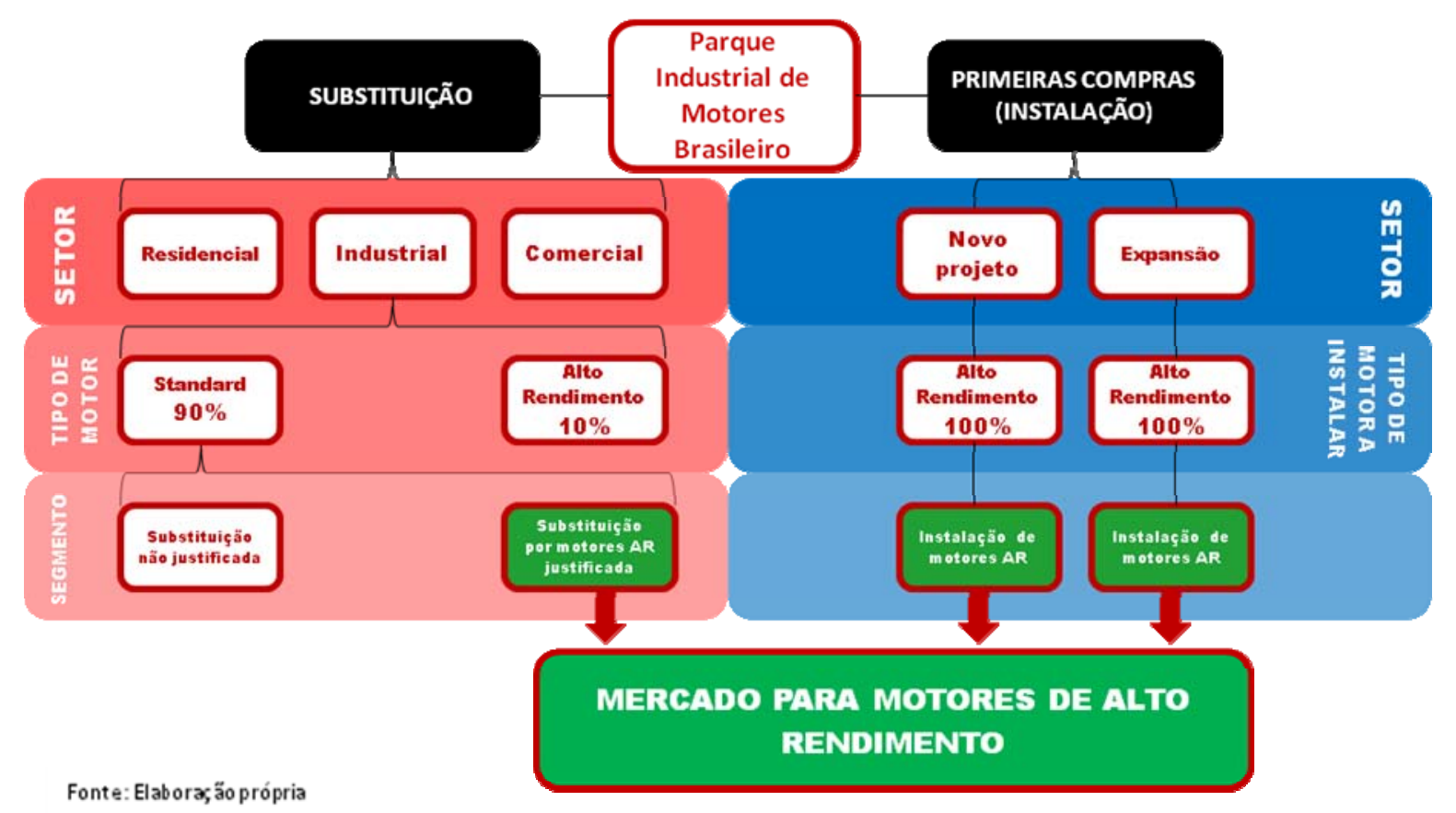

\subsubsection{ANÁLISE DA VIABILIDADE ECONÔMICA DA SUBSTITUIÇÃO}

Tendo em conta o ciclo de vida útil de um motor, é possível constatar que os custos de operação acabam por se tornar muito superiores aos custos iniciais de aquisição e instalação. É exatamente por esta razão que os motores de alto 
rendimento representam uma ótima alternativa. No entanto, nem sempre se justifica economicamente a utilização de um motor de alto rendimento. Deste modo, torna-se essencial proceder a uma análise caso a caso, não só para entender em que casos específicos a substituição de um motor standard por um motor de alto rendimento se justifica, mas também para compreender quais são os fatores principais a ter influência na análise.

\subsubsection{FATORES DETERMINANTES NA ANÁLISE}

Os principais fatores que devem ser considerados numa hipotética situação de substituição de um motor standard por um de alto rendimento, são os seguintes:

a) Rendimento dos motores: Deve-se ter disponível a curva de rendimento em função do carregamento (potência fornecida no eixo) dos motores em questão. Em certos casos, valores estatísticos normalizados ou valores de ensaio poderão ser suficientes, assim como valores típicos tirados da literatura, ou de outras fontes confiáveis. A confiabilidade da análise está, portanto, diretamente relacionada com a confiabilidade dos dados de rendimento. Atualmente, os catálogos de fabricantes fornecem valores de rendimento para várias condições de carga.

b) Tempo de operação: Expresso pelo número de horas ao longo das quais o motor permanece em operação - a base pode ser mensal ou diária. Esta informação pode também estar contida no ciclo de trabalho do motor. Em geral, aplicações em que o motor opera poucas horas por mês raramente justificam a utilização de um motor de alto rendimento.

c) Nível de carregamento: Além do número de horas em operação deve ser conhecido quanto da potência nominal do motor está em utilização quando o mesmo se encontra em operação. Esta informação é essencial tendo em vista que o rendimento do motor depende da carga que está sendo solicitada do mesmo. Esta informação também está contida no ciclo de carga. 
d) Custo da Energia: O custo do kWh, em geral, varia conforme o tipo de consumidor e concessionária, e é muito importante para se saber se vale a pena investir num novo motor ou não. Também pode variar em função do tipo de contrato entre o consumidor e a concessionária.

e) Taxas de juros: É indispensável conhecer as taxas em vigor, de modo a que se possa proceder a uma análise econômica eficiente.

f) Vida útil do motor: Uma vez que a possível economia que o motor de alto rendimento irá proporcionar ocorrerá ao longo da sua vida útil, torna-se necessário estimar qual a vida útil do motor.

\subsubsection{MÉTODOS DE ANÁLISE}

Existem vários tipos de análise econômica que podem ser efetuadas, envolvendo diferentes pontos de vista e com diferentes objetivos. Cada tipo de análise visa determinar um certo parâmetro que será usado para a tomada de decisão. $O$ tipo de análise a ser utilizado para a decisão também depende do ponto de vista adotado (consumidor, concessionária, terceiro, etc).

Deste modo, os métodos utilizados para analisar a viabilidade de um eventual investimento relacionado com a substituição de motores são os seguintes:

- Economia de energia

o Mensal

o Ao longo da vida útil

- Valor retornado

o Simples

o Capitalizado

- Tempo de retorno

o Simples 

o Capitalizado
o Taxa interna de retorno

\subsection{Economia de energia}

Este método visa quantificar a economia de energia que se conseguirá com a substituição de um motor por outro. No entanto, antes de se poder estimar a economia de energia obtida, é necessário calcular o consumo de cada motor. Como se pode observar na equação 1, o consumo de um motor é função da sua potência, tempo de operação, e rendimento.

$$
\begin{aligned}
& \text { Consumo }(k W h)=\frac{\text { Potêneia }(\mathrm{kW}) \times \text { Tempo de oporag̣ão(h) }}{\text { Rewdimento (9) }} \\
& C=\frac{P \times H}{\eta}
\end{aligned}
$$

Conhecendo o consumo dos dois motores a comparar, pode-se então determinar a economia de energia que um motor oferece face a outro através da equação 3.

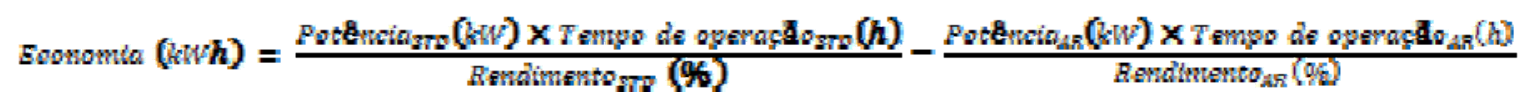

$$
\begin{aligned}
& \Delta C O M g=\frac{P_{S T D} \times H_{S T D}}{\eta_{T S Z}}-\frac{P_{A N} \times H_{A R}}{\eta_{A R}} \\
& \Delta C \text { Cons }=C_{C O n s_{S T P}}-\operatorname{Cons}_{A R}
\end{aligned}
$$




\subsection{Valor retornado}

Com a economia de energia quantificada, e conhecendo o custo da energia, é possível, através da equação 4 , calcular a economia em reais obtida com a troca de motores, ou seja, o valor retornado ao investidor por essa mesma troca.

Economaia $(R \$)=$ Economia $(\mathrm{kWh}) \times$ Custo Emergia (R\$)

$\Delta E=\Delta C O n s \times C E$

No entanto, para uma análise mais precisa da viabilidade da troca de motores, convém ter em consideração o custo de oportunidade do capital $i$. Utilizando o método do valor presente líquido (VPL), pode-se estimar o valor retornado capitalizado oferecido pela troca, como se pode observar na equação 5.

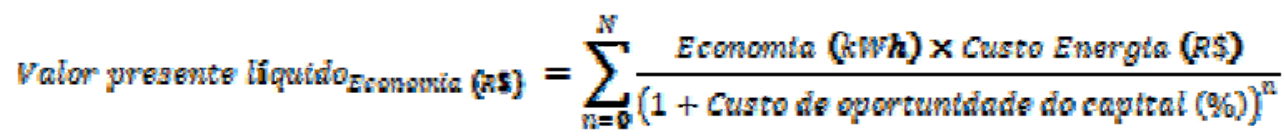

$$
\begin{aligned}
& V P L_{M E}=\sum_{n=1}^{N} \frac{\Delta C \cos s \times C E}{(1+i)^{n}}
\end{aligned}
$$

Deve-se assinalar que estes métodos de cálculo podem ser utilizados para estimar a poupança obtida ao longo de variados períodos de tempo (meses, anos, etc.), consoante a necessidade. Conhecendo a vida útil média dos motores em causa, torna-se assim possível estimar o valor retornado total que uma 
determinada troca de motores, teoricamente, permitirá ao longo do ciclo de vida do motor instalado.

\subsection{Tempo de retorno}

O tempo de retorno é um método que permite determinar o tempo necessário até se recuperar um dado investimento inicial. No caso deste trabalho, o tempo de retorno é utilizado de modo a se poder ter uma ideia do tempo que uma troca de motores demora a tornar-se rentável - i.e. o tempo em que o valor da energia economizada iguala o custo de investimento inicial.

No entanto, para efeitos deste trabalho, e visto que o foco incide principalmente na indústria, além do investimento inicial devem também ser considerados os custos derivados da parada de produção - isto é, durante o período de tempo que decorre desde o momento em que o processo de produção é interrompido até ao momento em que este é retomado. Estes custos são representados pela variável $C_{\text {paragem }}$ nas equações que se seguem.

No caso de ser imperativo comprar um novo motor (p.ex.: por avaria do motor atualmente instalado na linha de produção), o investimento inicial corresponde à diferença de preços entre os dois motores (equação 6).

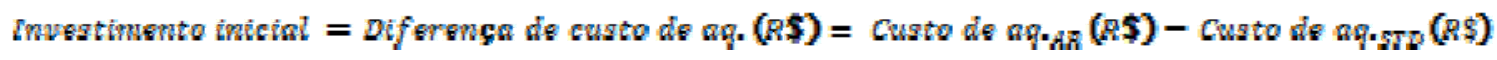

$$
t m v_{i}=\Delta C Q Q q=C a q_{g T D} \times C Q q_{A R}
$$

Por outro lado, se tratar de uma hipotética troca de motores, estando o atual motor em perfeitas condições de funcionamento, o investimento inicial é igual ao preço de compra do novo motor (equação 7). 


$$
I m v_{i}=c a q_{A R}
$$

Conhecendo o valor do investimento inicial e a economia decorrente da troca de motores ao longo de um dado período, pode-se assim determinar o tempo que decorre até a economia obtida igualar o investimento inicial. Considerando que essa igualdade ocorrerá necessariamente num qualquer período $k$, o tempo de retorno simples será igual a $k$, como se pode observar nas equações 8,9 e 10.

$$
\begin{aligned}
& \text { TRS }=k \\
& \text { em } \\
& \sum_{\mathrm{n}=0}^{k} \Delta E_{\mathrm{n}}=\ln w_{\mathrm{q}}+C_{\text {paragem }}
\end{aligned}
$$

Logo,

$$
\sum_{n=0}^{T R S} \Delta E_{\mathrm{n}}=\ln w_{\mathrm{i}}+c_{\text {paragem }}
$$

A unidade de TRS dependerá da unidade temporal de $\Delta E$, pelo que o seu valor variará de acordo com a unidade de tempo utilizada.

Há que salientar que, apesar de ajudar a dar uma idéia do quão rapidamente o investimento inicial poderá ser recuperado, o tempo de retorno simples deve apenas ser utilizado em conjunto com outros indicadores. De fato, por ser invariável face ao custo de oportunidade do capital, não pode ser utilizado como instrumento de decisão final ao investimento.

De modo a contornar este problema, utilizar-se-á também neste trabalho o conceito de tempo de retorno capitalizado, o qual permite obter o valor presente 
líquido da economia gerada ao longo do tempo, de acordo com uma determinada taxa de desconto $i$, tal como disposto na equação 11.

$$
\sum_{n=0}^{T M E} \frac{\Delta E_{n}}{\left(1+l^{n}\right.}=L m w_{i}+c_{\text {paragem }}
$$

Outro indicador útil é a taxa interna de retorno (TIR), através da qual se pode ter uma idéia da atratividade de um investimento. O seu valor corresponde à taxa necessária para que o valor presente líquido da economia gerada iguale 0 investimento inicial em $\mathrm{N}$ períodos. Quanto mais alta a taxa interna de retorno, maior será a atratividade do investimento. Note-se, no entanto, que a taxa interna de retorno deverá sempre ser superior ao custo de oportunidade de capital, caso contrário o investimento não será rentável. A taxa interna de retorno pode ser calculada através das equações 12 e 13.

$$
\begin{aligned}
& \sum_{\mathrm{n}=0}^{N} \frac{\Delta E_{n}}{(1+T I R)^{\mathrm{n}}}-I m w_{\mathrm{l}}-c_{\text {paragam }}=0 \\
& \sum_{\mathrm{n}=0}^{N} \frac{\Delta E_{\mathrm{n}}}{(1+T I R)^{\mathrm{n}}}=I w_{i}+c_{\text {paragsm }}
\end{aligned}
$$

Como forma de demonstrar a forma como estes cálculos são efetuados, considere-se um cenário em que, numa unidade de produção, se pretende proceder à substituição de todos os seus motores standard por motores de alto rendimento.

Tabela 6.5.2.4.1 - Parâmetros operacionais e comp aração entre motores standard e de alto rendimento

\begin{tabular}{|c|c|c|c|c|c|}
\multicolumn{2}{|c|}{ Parâmetros Operacionais } & \multicolumn{2}{c|}{ Motor Standard } & \multicolumn{2}{c|}{ Motor Alto Rendimento } \\
\hline Quantidade & Tempo de op. & Potência (cv) & Rendimento & Potência (cv) & Rendimento \\
\hline 50 & 3000 & 1 & $77,5 \%$ & 1 & $80,0 \%$ \\
\hline 10 & 5000 & 10 & $88,0 \%$ & 10 & $90,0 \%$ \\
\hline 1 & 6000 & 50 & $91,5 \%$ & 50 & $93,0 \%$ \\
\hline
\end{tabular}


No entanto, antes de se proceder à substituição, é necessário proceder-se a análise do investimento. Todos os motores na unidade são modelos WEG (de 2006) com 4 pólos, sendo que existem 50 motores de 1 CV, 10 motores de 10 CV, e 1 motor de $50 \mathrm{CV}$. Os parâmetros operacionais para cada categoria na unidade estão dispostos na 6.5.2.4.1. Considerando a tarifa de energia elétrica igual a $329 \mathrm{R} \$ / \mathrm{MWh}$ e uma taxa de desconto de $12 \%$, os resultados estão dispostos na Tabela 6.5.2.4.2.

\section{Tabela 6.5.2.4.2 - Análise do investimento}

\begin{tabular}{|c|c|c|c|c|c|c|c|c|c|c|c|}
\hline \multirow[b]{2}{*}{$\begin{array}{l}\text { Potência } \\
\text { (cv) }\end{array}$} & \multirow[b]{2}{*}{$\begin{array}{c}\text { Invest. } \\
\text { Inicial (RȘ) }\end{array}$} & \multicolumn{10}{|c|}{ Ano } \\
\hline & & 1 & 2 & 3 & 4 & 5 & 6 & 7 & 8 & 9 & 10 \\
\hline 1 & (5.516) & 1.464 & 1.307 & 1.167 & 1.042 & 930 & 830 & 741 & 662 & 591 & 528 \\
\hline 10 & $(4.820)$ & 3.055 & 2.728 & 2.436 & 2.175 & 1.942 & 1.734 & 1.548 & 1.382 & 1.234 & 1.102 \\
\hline 50 & $(1.272)$ & 1.280 & 1.143 & 1.020 & 911 & 813 & 726 & 648 & 579 & 517 & 461 \\
\hline VPL anual & (11.608) & 5.799 & 5.177 & 4.623 & 4.127 & 3.685 & 3.290 & 2.938 & 2.623 & 2.342 & 2.091 \\
\hline $\begin{array}{c}\text { VPL } \\
\text { acumulado }\end{array}$ & (11.608) & (5.809) & (632) & 3.991 & 8.118 & 11.800 & 15.093 & 18.031 & 20.654 & 22.996 & 25.087 \\
\hline
\end{tabular}

Fonte: Elaboração própria, com base em BDMotor (2008)

Como se pode verificar na Tabela 6.5.2.4.3, o tempo de retorno capitalizado não ultrapassa os dois anos e meio, e a taxa interna de retorno atinge os 35\%. Pode-se assim assumir que este investimento faria todo o sentido do ponto de vista da unidade de produção.

Tabela 6.5.2.4.3 - Resultados da análise do investimento

\begin{tabular}{c|c|c|c|}
$\begin{array}{c}\text { Taxa de } \\
\text { desconto }\end{array}$ & $\begin{array}{c}\text { Taxa interna } \\
\text { de retorno }\end{array}$ & $\begin{array}{c}\text { Tempo de } \\
\text { retorno } \\
\text { simples }\end{array}$ & $\begin{array}{c}\text { Tempo de } \\
\text { retorno } \\
\text { capitalizado }\end{array}$ \\
\hline $12 \%$ & $35 \%$ & 2,00 & 2,42 \\
\hline
\end{tabular}

Fonte: Elaboração própria, com base em BDMotor (2008) 


\section{SUBSTITUIÇÃO DE MOTORES COMO FORMA DE POTENCIALIZAR O LEILÃO DE EFICIÊNCIA ENERGÉTICA}

\subsection{METODOLOGIA}

Como introdução à metodologia de pesquisa deste trabalho, e antes de se poder integrar a questão dos motores de alto rendimento no contexto do leilão de eficiência energética, necessita-se primeiro compreender como é que, em primeiro lugar, os motores de alto rendimento são introduzidos na indústria. Deste modo, determinou-se haver dois processos distintos de introdução de motores de alto rendimento na indústria:

\section{- Substituição de motores;}

- Instalação de novos motores.

Ambos os processos são definidos em ciclos anuais. O processo de substituição de motores corresponde à mera troca direta de um motor standard em funcionamento por um motor de alto rendimento - a quantidade total potencial de trocas que poderá ocorrer através deste processo dependerá da dimensão e estrutura do parque industrial de motores elétricos de indução trifásicos.

Por sua vez, dentro deste número potencial de trocas, existe uma componente diretamente relacionada com a quantidade de motores que todos os anos avariam - a qual será estimada através da vida útil dos diversos motores em operação.

Relativamente ao processo de instalação de novos motores, assume-se que decorre principalmente através de duas formas:

- Criação de novas empresas e respectivas unidades de produção;

- Expansão das unidades existentes em empresas já ativas.

Em princípio, será difícil estimar a dimensão de cada um destes processos. Para tanto, determinar-se-á uma aproximação para o valor conjunto 
de ambos cruzando a dimensão atual da indústria brasileira com as taxas de crescimento esperadas para a mesma. Relacionando a dimensão atual da indústria brasileira com o número de motores em operação, poder-se-á, então, extrapolar a quantidade de motores a entrar em operação na indústria anualmente.

Conhecendo os valores correspondentes a estes dois processos de introdução de motores de alto rendimento na indústria, poder-se-á estimar os ganhos potenciais que a introdução destes oferece, em teoria, aos leilões de eficiência energética.

No entanto, este valor deverá apenas ser encarado como um indicador rudimentar, visto que recorre, por exemplo, a valores globais médios de fator de carga ou de horas de operação anuais. Além do mais, também não considera os casos em que, economicamente, não se justifica a troca por motor de alto rendimento, ou aqueles em que empresas pertencentes a um determinado setor muito dificilmente o farão por outros motivos. (Gráfico 7.1.1)

Assim, de modo a se poder proceder a uma análise mais precisa dos eventuais resultados da aplicação da substituição de motores de alto rendimento ao caso dos leilões de eficiência energética, é necessário possuir, em primeiro lugar, todos os dados necessários para tal. Idealmente, para se poder determinar com perfeita exatidão o potencial existente na indústria, seria necessário conhecer a constituição exata da população de motores em funcionamento na indústria, segmentados por:

\section{- Potência;}

- Marca, modelo e linha (Alto Rendimento ou Standard);

- Fator de carga médio;

- Tempo de operação médio;

- Idade;

- $\quad N^{\circ}$ de reparações e rendimento efetivo. 
Contudo, nenhum destes dados está disponível com grande exatidão. Apesar de certos estudos fornecerem algumas informações para determinados setores industriais, a informação existente sobre o parque industrial de motores elétricos é, em geral, extremamente básica e incompleta. Dessa forma, para que possam ser atingidos os objetivos a que este trabalho se propõe, será necessário elaborar estimativas para cada uma das variáveis.

Para cada uma das estimativas - dado o número de extrapolações que será necessário fazer devido à escassez da informação necessária e o grau de incerteza que daí advém - serão considerados diferentes cenários.

Em primeiro lugar, procurar-se-á chegar a uma estimativa do número total de motores elétricos existentes na indústria brasileira. Apesar de existirem alguns dados de vendas de motores elétricos em território brasileiro, a base para chegar a esse valor será o fato de se saber que, existiam aproximadamente 12 milhões de motores elétricos de indução trifásicos ativos em 2003 na indústria brasileira (Soares, 2008).

Dispondo desse valor, poder-se-á então cruzá-lo com estimativas da distribuição de motores existentes por potência e por linha, assim como valores médios de carga e horas de operação, de modo a, como foi referido acima, se chegar a um valor rudimentar para o potencial total de conservação de eletricidade através da introdução de motores de alto rendimento na indústria. $O$ objetivo, no entanto, é conseguir aperfeiçoar este valor através da obtenção de

Gráfico 7.1.1 - Mercado potencial para substituição por motores de alto rendimento

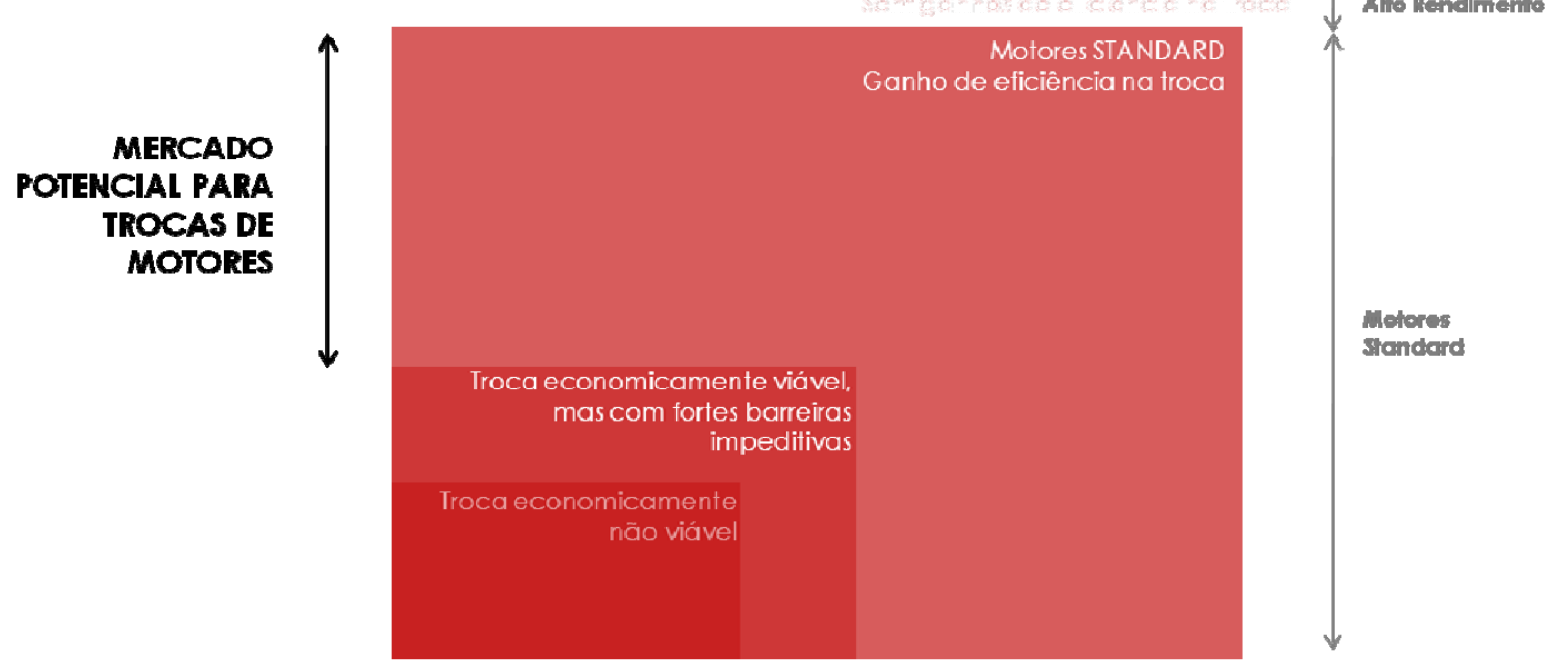

População Industrial de Mołores 
estimativas mais precisas das suas diversas variáveis.

No entanto, este valor potencial total de conservação energética, determinado através da estimativa da dimensão parque industrial de motores elétricos apenas fornece uma perspectiva geral do mercado. Deste modo, não permite identificar quaisquer oportunidades setoriais que possam fortalecer o leilão. Adicionalmente, como foi referido anteriormente, não faz qualquer distinção da quantidade de casos em que não se justifica a introdução de motores de alto rendimento - a qual é importante conhecer, pois condicionará a dimensão do mercado.

Assim, torna-se necessário, em segundo lugar, obter uma caracterização dos principais setores industriais brasileiros por:

- Consumo de eletricidade

o Peso nos custos de produção;

o Peso no consumo da indústria;

o Porcentagem que corresponde à força motriz.

- Custo de oportunidade do capital

- Tarifa média de eletricidade

- Tipos de processos de produção (ex: bombeamento, compressão, etc.)

- $\quad N^{0}$ de empresas/unidades de produção

- Dimensão das unidades

- Parque de motores elétricos

o $\mathrm{N}^{\mathrm{O}}$ de motores;

o Potência;

o Penetração de motores de alto rendimento;

o Fator de carga médio; 
o Tempo de operação médio;

o Idade;

o Taxa de reparações.

\section{- Barreiras à introdução/substituição de motores}

Idealmente, todos estes dados deveriam ser utilizados neste trabalho. No entanto, a inexistência ou o nível de incerteza relativamente a vários deles levou a que apenas alguns pudessem ser considerados no processo de identificação dos setores que maior peso poderá vir a ter no leilão em termos de substituição de motores. Pretendia-se também caracterizar os diferentes setores industriais por:

- Atratividade da troca de motores

o Intensidade das barreiras vs. Benefícios oferecidos ao setor

- Potencial oferecido ao leilão

o $\mathrm{N}^{0}$ de motores vs. Penetração de motores AR vs. Potencial de conservação médio por motor;

o Porcentagem de motores no setor que justificarão a troca, tanto economicamente como em termos energéticos.

Para os setores em que a informação disponível for suficiente, pretende-se montar cenários aproximados à realidade de cada setor. Deste modo, pretendese verificar como varia a viabilidade econômica dos projetos de introdução de motores de alto rendimento nos diferentes setores da indústria. A metodologia para estimar a viabilidade econômica da substituição de motores é detalhada na seção 6.5.2.4.

Em último lugar, tentar-se-á integrar os dados das várias indústrias com as estimativas da população industrial de motores, de modo a se poder ter uma idéia aproximada da população de motores por setor.

Há ainda que se destacar que, juntamente com as diversas estimativas de conservação energética, procurar-se-á calcular também a conservação 
conseguida ao nível das emissões de carbono, assim como o seu valor em créditos de carbono - como suporte a uma eventual criação de um mercado de certificados brancos. Este cálculo basear-se-á nas técnicas utilizadas atualmente ao nível do mercado de créditos de carbono. 


\subsubsection{MODELO DO PARQUE INDUSTRIAL DE MOTORES}

De modo a se poder obter estimativas acerca da constituição atual do parque industrial brasileiro de motores, assim como os efeitos que a instalação de motores mais eficientes poderiam vir a ter, tanto em termos energéticos como financeiros, foi criado um modelo em MS Excel.

Em primeiro lugar, foram introduzidos os dados correspondentes aos vários motores disponíveis no BDMotor. Os dados introduzidos no modelo, por motor, foram:

- Potência (em CV);

- Número de rotações por minuto (dependente do número de pólos);

- Níveis de rendimento a 50\%, 75\% e 100\% de carga;

- Tipo de motor (standard ou alto rendimento);

- Ano;

- Preço (em R\$);

- Número de série no BDMotor, para maior facilidade de posterior identificação, caso necessário.

Foram introduzidos dados no modelo para pelo menos um motor por combinação de escala de potência, $n^{0}$ de pólos e tipo de motor (standard e alto rendimento), para um total de 221 motores. Por exemplo, dentro dos motores de $1 \mathrm{CV}$, foram introduzidos os dados de 8 motores diferentes. (2, 4, 6 e 8 pólos, tanto standard como alto rendimento).

Tendo em conta que, atualmente, uma boa parte dos motores em funcionamento é de fabricação anterior a 2006, e visto que os modelos de 2006 apresentam um rendimento ligeiramente superior aos de anos anteriores, é provável que os cálculos obtidos para os ganhos de eficiência com troca de motores possam estar ligeiramente subestimados neste ponto. 
Foram seis os setores industriais considerados, sendo que um sétimo "setor" foi criado para representar o conjunto dos restantes setores da indústria brasileira. Os setores considerados foram os seguintes:

- Alimentos e bebidas;

- Química;

- Papel e celulose;

- Não ferrosos;

- Ferro-gusa e aço;

- Mineração e pelotização;

- Outros.

Inicialmente, pretendia-se considerar um conjunto mais amplo de setores, mas por falta de dados relativamente a grande parte deles, foi possível apenas considerar estes seis em maior detalhe.

O modelo foi criado de forma que, de modo independente para cada setor, se pudesse introduzir diferentes valores para uma série de características de operação dos motores, divididos por sete diferentes escalas de potência:

- $1-5 \mathrm{CV}$;

- $6-20 \mathrm{CV}$;

- $21-50 \mathrm{CV}$;

- $51-100 \mathrm{CV}$;

- $101-200 \mathrm{CV}$;

- $201-500 \mathrm{CV}$;

- $501+\mathrm{CV}$.

Por sua vez, as diferentes características operacionais que se entendeu considerar foram inseridas no modelo de modo a que se pudesse levar em conta 
as necessárias diferenças operacionais entre motores de diferentes escalões de potência (ex: vida útil ou tempo médio de operação anual).

- Distribuição dos motores por escala de potência;

- Carregamento médio;

- Rendimento médio (derivado automaticamente do anterior, juntamente com os dados dos motores introduzidos a partir do BDMotor);

- Tempo médio de operação de cada motor anual, em horas;

- Penetração de motores de alto rendimento;

- Vida útil;

- Vida máxima (função da vida útil);

- Taxa de reparação, em caso de avaria;

- Distribuição da população de motores por número de pólos.

- Fator de compensação (em \% do consumo energético total determinado).

O fator de compensação foi introduzido como forma de se poder compensar o fato de que nem todo o consumo de energia elétrica por parte de motores na indústria se dever a motores de indução trifásicos com pelo menos 1 $\mathrm{CV}$. Devido à falta de dados referentes à quantidade de motores de indução trifásicos com menos de $1 \mathrm{CV}$, ou de outros tipos de motores (p.ex.: motores de corrente contínua), entendeu-se ser esta a melhor forma de se evitar sobreestimar demasiado o consumo dos motores estudados.

Para cada escala de potência, foram também definidos, através do BDMotor, os vários motores que o poderiam constituir:

- 1 - 5 CV: 1, 1.5, 2, 3, 4 e 5;

- 6 - 20 CV: $6,7.5,10,12.5,15$ e 20 ; 
- 21 - 50 CV: 25, 30, 40 e 50;

- 51 - 100 CV: 60, 75 e 100;

- 101 - 200 CV: 125, 150, 175 e 200;

- 201 - 500 CV: 250, 300, 350, 400, 450 e 500;

- 501+ CV.

É importante notar que, por não existirem dados referentes aos mesmos no BDMotor, nenhum motor foi atribuído à escala de potência que representa os motores com potência superior a $500 \mathrm{CV}$.

Para efeitos do cálculo do consumo energético de cada escala de potência, devido à falta de dados que melhor indicassem a distribuição de potências dentro de cada escala, assumiu-se que todos os motores dentro de cada escala teriam pesos iguais. Por exemplo, na escala de 21 a $50 \mathrm{CV}$, a cada motor correspondeu um peso de $25 \%$, enquanto que na escala de 51 a $100 \mathrm{CV}$ os pesos equivaleram a $33,3 \%$.

Com todos estes dados introduzidos, o cálculo da energia elétrica gasta por segmento é feita automaticamente pelo modelo, cruzando as diversas distribuições de cada escala de potência e respectivas características operacionais com o intervalo obtido para o número total de motores que constitui o parque industrial brasileiro de motores.

Devido ao desconhecimento da exata distribuição de motores por escala de potência na indústria brasileira, foram também definidos vários cenários, com base em dados disponíveis das indústrias norte-americana e européia. Com base nestes cenários, foram calculados intervalos minimamente verossímeis para a distribuição por potência dentro de cada setor industrial, aos quais se recorreu posteriormente para a determinação dos diferentes potenciais de economia com trocas de motores existentes na indústria brasileira.

O cálculo dos diversos potenciais mínimos e máximos de economia por setor, escala de potência e segmento (motores em operação atualmente, motores a serem substituídos por avaria, e motores a entrarem em 
funcionamento anualmente) é efetuado automaticamente no arquivo, após introdução dos dados necessários. Em seguida registram-se os diversos tipos de potencial estimados pelo modelo, juntamente com os dados adicionais requeridos para o respectivo cálculo, conforme segue:

- Economia de energia elétrica (em GWh);

- Custo evitado de energia elétrica (em $\mathrm{R} \$$ )

o Requer tarifa média de energia elétrica (em $\mathrm{R} \$ / \mathrm{MWh}$ );

- Valor da energia economizada para o leilão de eficiência energética (em $R \$)$

o Requer estimativa para o preço médio no leilão (em $\mathrm{R} \$ / M W h) ;$

- Economia em emissões de $\mathrm{CO}_{2}\left(e m t\right.$ de $\left.\mathrm{CO}_{2}\right)$

- Requer estimativa do nível de emissões de $\mathrm{CO}_{2}$ por unidade de energia elétrica consumida (em $\mathrm{KgCO}_{2} / \mathrm{kWh}$ );

- Valor das emissões economizadas em créditos de carbono (em $\mathrm{R} \$)$

o Requer estimativa do valor dos créditos no mercado de carbono (em $\mathrm{R} \$ / \mathrm{t} \mathrm{CO}_{2}$ )

Todos estes valores são automaticamente estimados não só para o conjunto dos motores atualmente em operação no parque industrial brasileiro, como também para os motores a substituir por avaria, e também para os motores que virão a entrar em funcionamento como resultado da expansão da indústria brasileira.

\subsection{ESTIMATIVA DO NN TOTAL DE MOTORES EM OPERAÇÃO}

Como foi referido na seção anterior, para o objetivo a que este trabalho se propõe, é absolutamente crucial ter uma noção aproximada da dimensão do 
parque industrial de motores brasileiro. Deste modo, de modo a se poder extrapolar o número total atual de motores ativos na indústria brasileira, foi utilizado como base o valor de 12.000 .000 motores ativos em 2003 (Soares, 2008). Embora o autor não refira se esse número inclui motores com potência menor que $1 \mathrm{CV}$ (fora do escopo deste trabalho), assumiu-se que estes estariam incluídos. Para efeitos deste estudo, com suporte nos dados de vendas de motores elétricos trifásicos da ABINEE - Associação Brasileira da Indústria Elétrica e Eletrônica (Schaeffer, 2005), assumiu-se que 30\% destes motores seriam de $1 \mathrm{CV}$.

De modo a se poder estimar uma aproximação da evolução do número de motores em atividade na indústria brasileira de 2003 até aos dias de hoje, é lógica a necessidade de se ter de recorrer a índices com níveis de correlação suficientemente elevados com a evolução do número de motores ativos. Deste modo, vários índices econômicos foram ponderados, tendo-se chegado à conclusão que a evolução do consumo de energia elétrica na indústria seria a melhor opção, até porque, analisando a participação do consumo em força motriz no consumo de energia elétrica ao longo dos anos, pode-se verificar que, percentualmente, este tem se mantido praticamente constante (CNI, 2007). Assim, assume-se que através da evolução do consumo em força motriz se pode chegar a um valor aproximado da variação do $\mathrm{n}^{\circ}$ de motores em funcionamento. No entanto, este não é um índice perfeito, visto que alterações ao nível da capacidade utilizada ou a introdução gradual de instrumentos que melhoram o rendimento dos motores (p.ex.: AVAs - acionadores de velocidade ajustáveis) têm necessariamente um impacto ao nível da correlação entre o índice utilizado e a evolução do parque industrial de motores. 
Tabela 7.2.1 - Estimativa do no de motores em operação na indústria brasileira

\begin{tabular}{|c|c|c|c|}
\hline Ano & № motores em operação & $\begin{array}{c}\text { № motores em operação (com } \\
\text { mais de 1 CV) }\end{array}$ & $\begin{array}{c}\text { Crescimento do consumo de } \\
\text { energia elétrica }\end{array}$ \\
\hline 2003 & 12.000 .000 & 8.400 .000 & $5,28 \%$ \\
\hline 2004 & 12.847 .084 & 8.992 .959 & $7,06 \%$ \\
\hline 2005 & 13.094 .528 & 9.166 .169 & $1,93 \%$ \\
\hline 2006 & 13.695 .337 & 9.586 .736 & $4,59 \%$ \\
\hline 2007 & 14.382 .101 & 10.067 .471 & $5,01 \%$ \\
\hline 2008 & 14.725 .917 & 10.308 .142 & $2,39 \%$ \\
\hline 2010 & 13.908 .920 & 9.736 .244 & $-5,55 \%$ \\
\hline 2011 & 15.383 .266 & 10.768 .286 & $10,60 \%$ \\
\hline 2012 & 16.090 .896 & 11.263 .627 & $4,60 \%$ \\
\hline 2013 & 16.831 .077 & 11.781 .754 & $4,60 \%$ \\
\hline 2014 & 17.605 .307 & 12.323 .715 & $4,60 \%$ \\
\hline 2015 & 18.415 .151 & 12.890 .605 & $4,60 \%$ \\
\hline
\end{tabular}

Fonte: Elaboração própria, com base em MME (2010) 
Com suporte no valor base de 12.000 .000 motores ativos em 2003, e utilizando o índice de evolução de consumo de energia elétrica na indústria, determinou-se assim que, atualmente, deverão estar em funcionamento aproximadamente 16 milhões de motores de indução trifásicos na indústria brasileira, sendo que pouco mais de 11 milhões apresentam mais de $1 \mathrm{CV}$ de potência, como se pode visualizar na Tabela 7.2.1.

\subsection{ESTIMATIVA DO N DE MOTORES POR SETOR INDUSTRIAL}

Para se ter uma idéia de quais os setores industriais com maior potencial de atratividade na eventualidade da criação do leilão de eficiência energética no Brasil, é muito importante ter uma noção aproximada da quantidade de motores em operação em cada setor.

Dada a falta de dados de qualidade sobre a indústria brasileira, decidiu-se pela utilização de dados referentes às indústrias norte-americana (U.S. Department of Energy, 1998) e européia (Almeida et al, 2002). Apesar de haver naturais diferenças entre estas duas indústrias e a indústria brasileira, assume-se que cada setor industrial apresenta necessariamente determinadas particularidades inerentes à sua atividade, e que, portanto, independentemente do país ou região, tornam relativamente homogênea a composição do seu parque de motores. No entanto, para maior precisão, foram considerados múltiplos cenários de análise para a hipotética constituição da indústria brasileira.

\begin{tabular}{|c|c|c|c|c|c|c|c|}
\hline \multirow{2}{*}{ Brasil } & $1-10$ & $11-40$ & $41-100$ & $101-300$ & $>\mathbf{3 0 0}$ & & \\
\hline & $83,44 \%$ & $12,98 \%$ & $2,52 \%$ & $0,98 \%$ & $0,08 \%$ & & \\
\hline \multirow{2}{*}{ Estados Unidos } & $1-5$ & $6-20$ & $21-50$ & $51-100$ & $101-200$ & $201-500$ & $501-1000$ \\
\hline & $59,00 \%$ & $27,00 \%$ & $8,00 \%$ & $3,00 \%$ & $1,90 \%$ & $0,70 \%$ & $0,20 \%$ \\
\hline \multirow{2}{*}{ União Europeia } & $1-5$ & $6-13$ & $14-40$ & $41-95$ & $96-175$ & $176-670$ & $670+$ \\
\hline & $67,69 \%$ & $22,99 \%$ & $6,81 \%$ & $1,77 \%$ & $0,50 \%$ & $0,23 \%$ & $0,02 \%$ \\
\hline
\end{tabular}


Estes cenários incluem parâmetros para todos os setores industriais considerados no estudo, e apenas diferem uns dos outros na estruturação percentual por potência do parque industrial de cada setor, como se pode ver na Tabela 7.3.1. Utilizando parâmetros padrão de carga, tempo de operação e rendimento, ao cruzar as diversas estruturações percentuais por potência com

\begin{tabular}{|c|c|c|c|c|c|c|c|c|}
\hline \multirow[b]{2}{*}{ Setor } & \multicolumn{8}{|c|}{ Potência (CV) } \\
\hline & 1.5 & $6-20$ & 21.50 & 51-100 & $101-200$ & 201.500 & $501+$ & Total \\
\hline Alimentos e bebidas & 1.052 .198 & 172.065 & 14.166 & 9.518 & 3.766 & 2.500 & 721 & 1.254 .934 \\
\hline Química & 238.437 & 66.407 & 15.782 & 7.834 & 6.226 & 2.178 & 600 & 337.464 \\
\hline Papel e celulose & 108.615 & 23.492 & 7.958 & 6.056 & 2.359 & 1.729 & 413 & 150.622 \\
\hline Não ferrosos & 167.633 & 37.294 & 7.720 & 2.834 & 2.893 & 968 & 348 & 219.690 \\
\hline Ferro-gusa e aço & 230.532 & 51.303 & 10.622 & 3.902 & 3.988 & 1.351 & 489 & 302.187 \\
\hline Mineração e pelotização & 140.127 & 31.185 & 6.462 & 2.362 & 2.430 & 811 & 302 & 183.679 \\
\hline Outros & 4.272 .443 & 787.773 & 53.658 & 16.580 & 9.588 & 1.683 & 111 & 5.141 .836 \\
\hline
\end{tabular}

Fonte: Elaboração própria

valores fixos de consumo de energia elétrica por setor (correspondentes ao consumo por setor industrial no Brasil em 2005), obtêm-se as variações correspondentes no peso de cada setor em relação ao $\mathrm{n}^{\circ}$ de motores em operação na indústria.

Deste modo, após análise de todos os cenários, ao invés de se obter uma estimativa fixa para o número de motores em operação em cada setor da indústria brasileira, chega-se a um intervalo verossímil de valores no qual o real valor muito provavelmente estará incluído.

Para obter as estimativas do número mínimo e máximo de motores por setor, basta cruzar os valores mínimos e máximos obtidos através deste método

\begin{tabular}{|c|c|c|c|c|c|c|c|c|}
\hline & \multicolumn{8}{|c|}{ Potência (CV) } \\
\hline Setor & 1.5 & $6-20$ & $21-50$ & 51-100 & $101-200$ & 201500 & $501+$ & Total \\
\hline Alimentos e bebidas & 1.524 .626 & 249.316 & 20.530 & 13.792 & 5.455 & 3.615 & 1.043 & 1.818 .377 \\
\hline Química & 575.530 & 160.284 & 38.104 & 18.902 & 15.053 & 5.258 & 1.437 & 814.568 \\
\hline Papel e celulose & 548.026 & 118.583 & 40.208 & 30.592 & 11.947 & 8.706 & 2.031 & 760.093 \\
\hline Não ferrosos & 534.918 & 119.017 & 24.670 & 9.062 & 9.195 & 3.106 & 1.135 & 701.103 \\
\hline Ferro-gusa e aço & 735.408 & 163.622 & 33.916 & 12.450 & 12.674 & 4.290 & 1.568 & 963.928 \\
\hline Mineração e pelotização & 446.780 & 99.407 & 20.610 & 7.580 & 7.708 & 2.607 & 958 & 585.650 \\
\hline Outros & 7.324.183 & 1.350 .479 & 91.990 & 28.434 & 16.444 & 2.879 & 171 & 8.814 .580 \\
\hline
\end{tabular}

Fonte: Elaboração própria 
com a estimativa previamente calculada para a dimensão do parque industrial de motores brasileiro. Os valores obtidos para cada setor são apresentados nas Tabelas 7.3.2 e 7.3.3.

\subsection{ESTIMATIVA DO No DE MOTORES A ENTRAR EM FUNCIONAMENTO POR ANO E SETOR}

\begin{tabular}{|c|c|c|c|c|c|c|c|c|}
\hline \multirow[b]{2}{*}{ Setor } & \multicolumn{8}{|c|}{ Potência (CV) } \\
\hline & 1.5 & 6-20 & 21.50 & $51-100$ & $101-200$ & $201-500$ & $501+$ & Total \\
\hline Alimentos e bebidas & 48.401 & 7.915 & 652 & 438 & 173 & 115 & 33 & 57.727 \\
\hline Química & 10.968 & 3.055 & 726 & 360 & 286 & 100 & 28 & 15.523 \\
\hline Papel e celulose & 4.996 & 1.081 & 366 & 279 & 109 & 80 & 19 & 6.929 \\
\hline Não ferrosos & 7.711 & 1.716 & 355 & 130 & 133 & 45 & 16 & 10.106 \\
\hline Ferro-gusa e aço & 10.604 & 2.360 & 489 & 179 & 183 & 62 & 22 & 13.901 \\
\hline Mineração e pelotização & 6.446 & 1.435 & 297 & 109 & 112 & 37 & 14 & 8.449 \\
\hline Outros & 196.532 & 36.238 & 2.468 & 763 & 441 & 77 & 5 & 236.524 \\
\hline
\end{tabular}

Fonte: Elaboração própria

Após ter determinado um valor aproximado para a quantidade de motores em operação atualmente no Brasil, pode-se utilizar esse valor para, através da mesma metodologia, se conseguir determinar o número de motores que anualmente entrarão em funcionamento na indústria, por setor e categoria de potência. Os resultados obtidos podem ser visualizados nas Tabelas 7.4.1 e 7.4.2.

\begin{tabular}{|c|c|c|c|c|c|c|c|c|}
\hline \multirow[b]{2}{*}{ Setor } & \multicolumn{8}{|c|}{ Potência (CV) } \\
\hline & 1.5 & $6-20$ & 21.50 & 51-100 & $101-200$ & 201.500 & $501+$ & Total \\
\hline Alimentos e bebidas & 70.133 & 11.469 & 944 & 634 & 251 & 166 & 48 & 83.645 \\
\hline Química & 26.474 & 7.373 & 1.753 & 869 & 692 & 242 & 66 & 37.470 \\
\hline Papel e celulose & 25.209 & 5.455 & 1.850 & 1.407 & 550 & 400 & 93 & 34.964 \\
\hline Não ferrosos & 24.606 & 5.475 & 1.135 & 417 & 423 & 143 & 52 & 32.251 \\
\hline Ferro-gusa e aço & 33.829 & 7.527 & 1.560 & 573 & 583 & 197 & 72 & 44.341 \\
\hline Mineração e pelotização & 20.552 & 4.573 & 948 & 349 & 355 & 120 & 44 & 26.940 \\
\hline Outros & 336.912 & 62.122 & 4.232 & 1.308 & 756 & 132 & 8 & 405.471 \\
\hline
\end{tabular}




\subsection{ESTIMATIVA DO N DE AVARIAS POR ANO E SETOR}

Conhecendo aproximadamente a estrutura setorial do parque industrial de motores, torna-se possível estimar o $\mathrm{n}^{\circ}$ aproximado de avarias que ocorre por

\begin{tabular}{|c|c|c|}
\hline \multicolumn{2}{|c|}{ Tabela 7.5.1 - Vida útil e probabilidade de avaria anual por motor } \\
\hline Potência (CV) & Tempo de vida (anos) & Probabilidade de avaria \\
\hline 1 a 10 & 12 & $8,33 \%$ \\
\hline 11 a 100 & 15 & $6,67 \%$ \\
\hline Maior que 100 & 20 & $5,00 \%$ \\
\hline
\end{tabular}

Fonte: Elaboração própria, com base em Schaeffer (2005)

ano, por setor e classe de potência.

A existência de fortes barreiras à substituição de motores standard por motores de alto rendimento em certos setores torna esta estimativa muito importante, visto que quando ocorre uma avaria e a substituição do motor é garantida, várias dessas barreiras não se apresentam tão fortes.

Para este trabalho, resolveu-se assumir que a probabilidade de um dado motor ter uma avaria num determinado ano tem uma relação direta com a vida útil do motor, dependendo exclusivamente desse fator. Portanto, quanto maior a vida útil, menor a probabilidade de avaria. Na Tabela 7.5.1 pode-se observar a probabilidade de avaria de um motor, consoante a sua potência. Cruzando a probabilidade de cada tipo de motor avariar num ano com a composição do parque industrial de motores de cada setor, obtém-se assim uma estimativa para o número de avarias anual por categoria de potência.

\subsection{ESTIMATIVA DO N DE SUBSTITUIÇÕES POR ANO E SETOR}

A partir do número de avarias anual, pode-se então determinar o número de motores que efetivamente são substituídos anualmente devido a avaria. No entanto, para se poder chegar a esta estimativa, é necessário conhecer a taxa de reparações de cada motor, consoante a sua potência - isto é, a quantidade de 
motores que, ao avariar, é reparado em vez de ser substituído. Há que salientar que quanto maior for a taxa de reparações para uma determinada categoria de potência de motores, menor será o potencial mercado para substituição dos mesmos.

\begin{tabular}{|c|c|c|c|c|c|c|c|}
\hline \multicolumn{7}{|c|}{ Tabela 7.6.1 - Taxa de reparação por escalão de potência } \\
\hline Potência (CV) & $1-5$ & $6-20$ & $21-50$ & $51-100$ & $101-200$ & $201-500$ & $501-1000$ \\
\hline Taxa de reparação & $20 \%$ & $61 \%$ & $81 \%$ & $90 \%$ & $91 \%$ & $91 \%$ & $91 \%$ \\
\hline
\end{tabular}

Fonte: U.S. Department of Energy (1998)

Visto não se terem encontrado dados relativos à taxa de substituições na indústria brasileira, resolveu-se utilizar os dados que constam num estudo sobre a indústria norte-americana, como se pode observar na Tabela 7.6.1.

\begin{tabular}{|c|c|c|c|c|c|c|c|c|}
\hline & \multicolumn{8}{|c|}{ Potência (CV) } \\
\hline Setor & 1.5 & $6-20$ & 21.50 & $51-100$ & $101-200$ & 201.500 & $501+$ & Total \\
\hline Alimentos e bebidas & 70.147 & 5.592 & 179 & 63 & 17 & 11 & 3 & 76.013 \\
\hline Química & 15.896 & 2.158 & 200 & 52 & 28 & 10 & 3 & 18.347 \\
\hline Papel e celulose & 7.241 & 763 & 101 & 40 & 11 & 8 & 2 & 8.166 \\
\hline Não ferrosos & 11.176 & 1.212 & 98 & 19 & 13 & 4 & 2 & 12.523 \\
\hline Ferro-gusa e aço & 15.369 & 1.667 & 135 & 26 & 18 & 6 & 2 & 17.223 \\
\hline Mineração e pelotização & 9.342 & 1.014 & 82 & 16 & 11 & 4 & 1 & 10.469 \\
\hline Outros & 284.830 & 25.603 & 680 & 111 & 43 & 8 & 0 & 311.274 \\
\hline
\end{tabular}

Fonte: Elaboração própria

\begin{tabular}{|c|c|c|c|c|c|c|c|c|}
\hline Setor & 1.5 & $6-20$ & 21.50 & $51-100$ & $101-200$ & $201-500$ & $501+$ & Total \\
\hline Alimentos e bebidas & 101.642 & 8.103 & 260 & 92 & 25 & 16 & 5 & 110.142 \\
\hline Papel e celulose & 36.535 & 3.854 & 509 & 204 & 54 & 39 & 9 & 41.204 \\
\hline Não ferrosos & 35.661 & 3.868 & 312 & 60 & 41 & 14 & 5 & 39.963 \\
\hline Ferro-gusa e aço & 49.027 & 5.318 & 430 & 83 & 57 & 19 & 7 & 54.941 \\
\hline Mineração e pelotização & 29.785 & 3.231 & 261 & 51 & 35 & 12 & 4 & 33.378 \\
\hline Outros & 488.279 & 43.891 & 1.165 & 190 & 74 & 13 & 1 & 533.612 \\
\hline
\end{tabular}

Fonte: Elaboração própria

Cruzando estes dados com as estimativas já feitas para o número de avarias anual, é assim possível ter uma noção da quantidade de oportunidades 
que surgem por ano para substituição de motores na indústria brasileira, como se pode visualizar nas Tabelas 7.6.2 e 7.6.3. 


\subsection{ESTIMATIVA DO POTENCIAL DE CONSERVAÇÃO}

Com as estimativas da composição setorial do parque industrial de motores brasileiro, e conhecendo também a forma como o mesmo evolui através

\section{Tabela 7.7.1 - Estimativa do consumo atual dos motores a substituir por avaria, por setor e classe de potência (cenário mínimo, em GWh)}

\begin{tabular}{|c|c|c|c|c|c|c|c|c|}
\hline \multirow[b]{2}{*}{ Setor } & \multicolumn{8}{|c|}{ Potência (CV) } \\
\hline & 1.5 & $6-20$ & 21.50 & $51-100$ & $101-200$ & 201.500 & $501+$ & Total \\
\hline Alimentos e bebidas & 674,28 & 219,80 & 26,09 & 21,98 & 11,04 & 12,16 & 26,33 & $1.721,41$ \\
\hline Química & 162,89 & 105,47 & 28,75 & 19,17 & 21,20 & 18,51 & 61,98 & $1.377,18$ \\
\hline Papel e celulose & 72,66 & 35,21 & 16,30 & 17,07 & 9,12 & 15,82 & 33,40 & 784,19 \\
\hline Não ferrosos & 122,79 & 49,94 & 14,01 & 7,93 & 12,36 & 9,02 & 28,87 & 733,61 \\
\hline Ferro-gusa e aço & 168,87 & 68,70 & 19,27 & 10,92 & 17,04 & 12,60 & 39,87 & $1.012,82$ \\
\hline Mineração e pelotização & 102,65 & 41,76 & 11,72 & 6,61 & 10,37 & 7,56 & 24,18 & 614,12 \\
\hline Outros & $1.632,44$ & 775,47 & 70,80 & 32,81 & 23,23 & 11,90 & 18,47 & $4.050,05$ \\
\hline
\end{tabular}

Fonte: Elaboração própria

Tabela 7.7.2 - Estimativa do consumo atual dos motores a substituir por avaria, por setore classe de potência (cenário máximo, em GWh)

\begin{tabular}{|c|c|c|c|c|c|c|c|c|}
\hline \multirow[b]{2}{*}{ Setor } & \multicolumn{8}{|c|}{ Potência (CV) } \\
\hline & 1.5 & $6-20$ & 21.50 & 51-100 & $101-200$ & 201.500 & $501+$ & Total \\
\hline Alimentos e bebidas & 977,02 & 318,49 & 37,81 & 31,86 & 16,00 & 17,59 & 38,14 & $2.494,00$ \\
\hline Papel e celulose & 366,60 & 177,75 & 82,38 & 86,24 & 46,23 & 79,70 & 168,71 & $3.960,06$ \\
\hline Não ferrosos & 391,85 & 159,39 & 44,76 & 25,38 & 39,28 & 28,96 & 92,20 & $2.342,28$ \\
\hline Outros & $2.798,47$ & $1.329,38$ & 121,39 & 56,27 & 39,84 & 20,35 & 31,66 & $6.942,93$ \\
\hline
\end{tabular}

Fonte: Elaboração própria

de processos de reparação, substituição, e instalação de novas unidades, podese assim passar à determinação do potencial de conservação energético que o mesmo oferece. No entanto, para chegar a tal valor, é necessário comparar o cenário atual (em que se assume que a penetração de motores de alto rendimento é igual a 15\%) com um cenário hipotético, no qual todos os motores seriam de alto rendimento. O potencial de conservação de energia elétrica será assim, igual à diferença entre os consumos correspondentes em cada cenário. 
Tabela 7.7.3 - Estimativa do consumo potencial dos motores a substituir por avaria se todos fossem de alto rendimento, por setor e classe de potência (cenário mínimo, em GWh)

\begin{tabular}{|c|c|c|c|c|c|c|c|c|}
\hline \multirow[b]{2}{*}{ Setor } & \multicolumn{8}{|c|}{ Potência (CV) } \\
\hline & 1.5 & $6-20$ & 21.50 & $51-100$ & 101.200 & 201.500 & $501+$ & Total \\
\hline Alimentos e bebidas & 651,44 & 215,11 & 25,59 & 21,70 & 10,89 & 12,15 & 25,74 & $1.683,36$ \\
\hline Papel e celulose & 70,19 & 34,46 & 15,99 & 16,85 & 8,99 & 15,81 & 32,97 & 774,09 \\
\hline Não ferrosos & 118,64 & 48,87 & 13,74 & 7,83 & 12,18 & 9,01 & 28,40 & 721,50 \\
\hline Outros & $1.577,16$ & 758,92 & 69,46 & 32,38 & 22,90 & 11,89 & 18,03 & $3.953,85$ \\
\hline
\end{tabular}

Fonte: Elaboração própria

Utilizando as estimativas obtidas para cada setor industrial, e combinandoas com os dados médios de operação para cada categoria de potência de motores dentro do setor (carga, tempo de operação, rendimento, penetração de motores de alto rendimento, etc), obtém-se uma estimativa para o consumo para

Tabela 7.7.4 - Estimativa do consumo potencial dos motores a substituir por avaria se todos fossem de alto rendimento, por setor e classe de potência (cenário máximo, em GWh)

\begin{tabular}{|c|c|c|c|c|c|c|c|c|}
\hline \multirow[b]{2}{*}{ Setor } & \multicolumn{8}{|c|}{ Potência (CV) } \\
\hline & 1.5 & $6-20$ & 21.50 & $51-100$ & $101-200$ & 201.500 & $501+$ & Total \\
\hline Alimentos e bebidas & 943,93 & 311,69 & 37,09 & 31,45 & 15,77 & 17,58 & 37,30 & $2.438,88$ \\
\hline Química & 379,87 & 249,15 & 68,09 & 45,67 & 50,53 & 44,63 & 147,36 & $3.274,37$ \\
\hline Papel e celulose & 354,18 & 173,96 & 80,82 & 85,13 & 45,57 & 79,64 & 166,53 & $3.909,05$ \\
\hline Não ferrosos & 378,58 & 155,99 & 43,91 & 25,05 & 38,72 & 28,94 & 90,68 & $2.303,66$ \\
\hline Ferro-gusa e aço & 520,47 & 214,45 & 60,37 & 34,42 & 53,38 & 40,03 & 124,89 & $3.172,77$ \\
\hline Mineração e pelotização & 316,20 & 130,28 & 36,68 & 20,95 & 32,47 & 24,30 & 75,90 & $1.928,16$ \\
\hline Outros & $2.703,70$ & $1.301,01$ & 119,08 & 55,54 & 39,27 & 20,34 & 30,91 & $6.778,01$ \\
\hline
\end{tabular}

Fonte: Elaboração própria

Tabela 7.7.5 - Estimativa da economia de energia elétrica potencial com motores a substituir por avaria anualmente, por setor e classe de potência (cenário mínimo, em GWh)

\begin{tabular}{|c|c|c|c|c|c|c|c|c|}
\hline \multirow[b]{2}{*}{ Setor } & \multicolumn{8}{|c|}{ Potência (CV) } \\
\hline & 1.5 & $6-20$ & 21.50 & 51-100 & $101-200$ & $201-500$ & $501+$ & Total \\
\hline Alimentos e bebidas & 10,34 & 2,12 & 0,22 & 0,13 & 0,07 & 0,00 & 0,26 & 13,15 \\
\hline Papel e celulose & 1,64 & 0,50 & 0,21 & 0,15 & 0,09 & 0,01 & 0,29 & 2,87 \\
\hline Não ferrosos & 2,39 & 0,61 & 0,15 & 0,06 & 0,10 & 0,00 & 0,27 & 3,59 \\
\hline Mineração e pelotização & 1,99 & 0,51 & 0,13 & 0,05 & 0,08 & 0,00 & 0,23 & 2,99 \\
\hline Outros & 27,91 & 8,35 & 0,68 & 0,21 & 0,17 & 0,00 & 0,22 & 37,55 \\
\hline
\end{tabular}

Fonte: Elaboração própria 
cada setor.

É importante destacar que, mais uma vez, é utilizado um intervalo de valores - são utilizados tanto o limite mínimo como o máximo do intervalo estimado anteriormente com recurso aos vários cenários teorizados.

De modo a se poder aferir o potencial de conservação, o mesmo método é

Tabela 7.7.6 - Estimativa da economia de energia elétrica potencial com motores a substituir por avaria, por setor e classe de potência (cenário máximo, em GWh)

\begin{tabular}{|c|c|c|c|c|c|c|c|c|}
\hline Setor & \multicolumn{8}{|c|}{ Potência (CV) } \\
\hline Alimentos e bebidas & 15,50 & 3,19 & 0,34 & 0,19 & 0,11 & 0,01 & 0,40 & 19,73 \\
\hline Papel e celulose & 2,45 & 0,75 & 0,31 & 0,22 & 0,13 & 0,01 & 0,43 & 4,30 \\
\hline Não ferrosos & 3,58 & 0,92 & 0,23 & 0,09 & 0,15 & 0,01 & 0,41 & 5,38 \\
\hline Mineração e pelotização & 2,98 & 0,76 & 0,19 & 0,07 & 0,13 & 0,00 & 0,34 & 4,48 \\
\hline Outros & 41,86 & 12,53 & 1,02 & 0,32 & 0,25 & 0,01 & 0,33 & 56,32 \\
\hline
\end{tabular}

Fonte: Elaboração própria

Tabela 7.7.7 - Estimativa do consumo potencial com motores a entrar em funcionamento, por setor e classe de potência (cenário mínimo, em GWh)

\begin{tabular}{|c|c|c|c|c|c|c|c|c|}
\hline \multirow[b]{2}{*}{ Setor } & \multicolumn{8}{|c|}{ Potência (CV) } \\
\hline & 1.5 & $6-20$ & 21.50 & $51-100$ & $101-200$ & 201.500 & $501+$ & Total \\
\hline Alimentos e bebidas & 465,25 & 311,11 & 94,74 & 151,68 & 112,89 & 124,27 & 269,11 & $1.307,30$ \\
\hline Papel e celulose & 50,13 & 49,84 & 59,20 & 117,76 & 93,22 & 161,71 & 341,47 & 665,37 \\
\hline Não ferrosos & 84,73 & 70,69 & 50,87 & 54,73 & 126,32 & 92,20 & 295,16 & 591,99 \\
\hline Mineração e pelotização & 70,83 & 59,11 & 42,57 & 45,63 & 106,05 & 77,31 & 247,12 & 495,65 \\
\hline Outros & $1.126,38$ & $1.097,58$ & 257,13 & 226,36 & 237,44 & 121,62 & 188,81 & $3.077,47$ \\
\hline
\end{tabular}

Fonte: Elaboração própria

Tabela 7.7.8 - Estimativa do consumo potencial com motores a entrar em funcionamento, por setor e classe de potência (cenário máximo, em GWh)

\begin{tabular}{|c|c|c|c|c|c|c|c|c|}
\hline \multirow[b]{2}{*}{ Setor } & \multicolumn{8}{|c|}{ Potência (CV) } \\
\hline & 1.5 & $6-20$ & 21.50 & $51-100$ & $101-200$ & 201.500 & $501+$ & Total \\
\hline Alimentos e bebidas & 674,14 & 450,78 & 137,30 & 219,82 & 163,51 & 179,84 & 389,89 & $1.894,02$ \\
\hline Papel e celulose & 252,95 & 251,59 & 299,18 & 595,04 & 472,59 & 814,70 & $1.724,54$ & $3.360,34$ \\
\hline Não ferrosos & 270,38 & 225,60 & 162,55 & 175,11 & 401,49 & 296,07 & 942,47 & $1.890,28$ \\
\hline Outros & $1.930,95$ & $1.881,59$ & 440,82 & 388,25 & 407,22 & 208,06 & 323,67 & $5.275,66$ \\
\hline
\end{tabular}

Fonte: Elaboração própria 
aplicado num cenário em que a penetração de motores de alto rendimento é de 100\%. O consumo obtido neste cenário é então subtraído ao consumo obtido com a taxa de penetração de motores de alto rendimento que se supõe atual, obtendo-se deste modo o potencial total de conservação de energia elétrica com a troca por motores de alto rendimento existente na indústria brasileira, como se pode ver nas Tabelas 7.7.13 e 7.7.14.

Analogamente, pode-se também calcular o potencial de conservação oferecido pelas substituições que ocorrem anualmente por avaria. Basta utilizar os dados computados anteriormente, e aplicar a metodologia descrita nesta seção. Os resultados obtidos apresentam-se nas Tabelas 7.7.1 a 7.7.6.

Por sua vez, o potencial de conservação relacionado com a entrada de novas unidades em funcionamento está disposto nas Tabelas 7.7.7 a 7.7.12.

\begin{tabular}{|c|c|c|c|c|c|c|c|c|}
\hline & \multicolumn{8}{|c|}{ Potência (CV) } \\
\hline Setor & 1.5 & $6-20$ & 21.50 & $51-100$ & $101-200$ & $201-500$ & $501+$ & Total \\
\hline Alimentos e bebidas & 449,49 & 304,47 & 92,94 & 149,73 & 111,28 & 124,18 & 263,16 & $1.278,41$ \\
\hline Química & 108,59 & 146,09 & 102,41 & 130,59 & 213,60 & 189,04 & 623,83 & $1.147,33$ \\
\hline Papel e celulose & 48,43 & 48,78 & 58,07 & 116,24 & 91,89 & 161,59 & 337,07 & 656,80 \\
\hline Não ferrosos & 81,86 & 69,18 & 49,90 & 54,03 & 124,52 & 92,13 & 290,29 & 582,22 \\
\hline Ferro-gusa e aço & 112,58 & 95,17 & 68,65 & 74,41 & 171,71 & 128,75 & 400,86 & 803,99 \\
\hline Mineração e pelotização & 68,43 & 57,85 & 41,76 & 45,05 & 104,54 & 77,25 & 243,05 & 487,47 \\
\hline Outros & $1.088,24$ & $1.074,16$ & 252,24 & 223,45 & 234,06 & 121,53 & 184,32 & $3.004,37$ \\
\hline
\end{tabular}

Fonte: Elaboração própria

Tabela 7.7.10 - Estimativa do consumo potencial com motores a entrar em funcionamento se todos fossem de alto rendimento, por setor e classe de potência (cenário máximo, em GWh)

\begin{tabular}{|c|c|c|c|c|c|c|c|c|}
\hline \multirow[b]{2}{*}{ Setor } & \multicolumn{8}{|c|}{ Potência (CV) } \\
\hline & 1.5 & $6-20$ & 21.50 & $51-100$ & $101-200$ & 201.500 & $501+$ & Total \\
\hline Alimentos e bebidas & 651,31 & 441,16 & 134,69 & 217,00 & 161,18 & 179,70 & 381,27 & $1.852,16$ \\
\hline Papel e celulose & 244,39 & 246,22 & 293,49 & 587,39 & 465,86 & 814,10 & $1.702,32$ & $3.317,05$ \\
\hline Não ferrosos & 261,22 & 220,79 & 159,46 & 172,85 & 395,78 & 295,85 & 926,92 & $1.859,11$ \\
\hline Outros & $1.865,55$ & $1.841,43$ & 432,44 & 383,26 & 401,43 & 207,91 & 315,98 & $5.150,34$ \\
\hline
\end{tabular}

Fonte: Elaboração própria 
Tabela 7.7.11 - Estimativa da economia de energia elétric a potencial com motores a entrar em funcionamento, por setor e classe de potência (cenário mínimo, em GWh)

\begin{tabular}{|c|c|c|c|c|c|c|c|c|}
\hline \multirow[b]{2}{*}{ Setor } & \multicolumn{8}{|c|}{ Potência (CV) } \\
\hline & 1.5 & $6-20$ & 21.50 & $51-100$ & $101-200$ & $201-500$ & $501+$ & Total \\
\hline Alimentos e bebidas & 7,13 & 3,01 & 0,82 & 0,88 & 0,73 & 0,04 & 2,69 & 15,30 \\
\hline Química & 1,76 & 1,47 & 0,92 & 0,79 & 1,43 & 0,06 & 4,51 & 10,94 \\
\hline Papel e celulose & 1,13 & 0,71 & 0,75 & 1,01 & 0,88 & 0,08 & 2,93 & 7,48 \\
\hline Não ferrosos & 1,65 & 0,87 & 0,55 & 0,40 & 1,03 & 0,04 & 2,80 & 7,34 \\
\hline Ferro-gusa e aço & 2,25 & 1,18 & 0,76 & 0,55 & 1,41 & 0,05 & 3,82 & 10,04 \\
\hline Mineração e pelotização & 1,37 & 0,72 & 0,46 & 0,34 & 0,86 & 0,03 & 2,33 & 6,12 \\
\hline Outros & 19,26 & 11,82 & 2,47 & 1,47 & 1,71 & 0,05 & 2,26 & 39,03 \\
\hline
\end{tabular}

Fonte: Elaboração própria

Tabela 7.7.12 - Estimativa da economia de energia elétrica potencial com motores a entrar em funcionamento, por setor e classe de potência (cenário máximo, em GWh)

\begin{tabular}{|c|c|c|c|c|c|c|c|c|}
\hline & \multicolumn{8}{|c|}{ Potência (CV) } \\
\hline Setor & $1-5$ & $6-20$ & $21-50$ & $51-100$ & $101-200$ & 201.500 & $501+$ & Total \\
\hline Alimentos e bebidas & 10,70 & 4,51 & 1,22 & 1,32 & 1,09 & 0,06 & 4,04 & 22,95 \\
\hline Papel e celulose & 1,69 & 1,06 & 1,12 & 1,51 & 1,33 & 0,12 & 4,39 & 11,23 \\
\hline Não ferrosos & 2,47 & 1,30 & 0,83 & 0,61 & 1,54 & 0,06 & 4,19 & 10,99 \\
\hline Outros & 28,89 & 17,74 & 3,70 & 2,20 & 2,56 & 0,07 & 3,40 & 58,55 \\
\hline
\end{tabular}

Fonte: Elaboração própria

Tabela 7.7.13 - Estimativa da economia de energia elétrica potencial no parque industrial brasileiro, por setor e classe de potência (cenário mínimo, em GWh)

\begin{tabular}{|c|c|c|c|c|c|c|c|c|}
\hline \multirow[b]{2}{*}{ Setor } & \multicolumn{8}{|c|}{ Potência (CV) } \\
\hline & 1.5 & $6-20$ & 21.50 & $51-100$ & 101.200 & 201.500 & $501+$ & Total \\
\hline Alimentos e bebidas & 155,03 & 65,33 & 17,72 & 19,19 & 15,82 & 0,90 & 58,52 & 332,50 \\
\hline Papel e celulose & 24,56 & 15,39 & 16,28 & 21,90 & 19,20 & 1,73 & 63,59 & 162,64 \\
\hline Não ferrosos & 35,79 & 18,82 & 12,06 & 8,78 & 22,43 & 0,85 & 60,77 & 159,50 \\
\hline Outros & 418,62 & 257,06 & 53,65 & 31,93 & 37,10 & 0,99 & 49,22 & 848,58 \\
\hline
\end{tabular}

Fonte: Elaboração própria

\begin{tabular}{|c|c|c|c|c|c|c|c|c|}
\hline Setor & $1-5$ & $6-20$ & 21.50 & $51-100$ & $101-200$ & 201.500 & $501+$ & Total \\
\hline Alimentos e bebidas & 232,57 & 98,00 & 26,59 & 28,79 & 23,72 & 1,36 & 87,79 & 498,82 \\
\hline Não ferrosos & 53,65 & 28,21 & 18,11 & 13,19 & 33,50 & 1,28 & 91,06 & 239,00 \\
\hline Ferro-gusa e aço & 73,50 & 38,64 & 24,81 & 18,06 & 46,01 & 1,77 & 124,82 & 327,61 \\
\hline Mineração e pelotização & 44,70 & 23,50 & 15,09 & 11,01 & 28,02 & 1,07 & 75,95 & 199,35 \\
\hline Outros & 627,94 & 385,59 & 80,48 & 47,93 & 55,68 & 1,48 & 73,83 & $1.272,93$ \\
\hline
\end{tabular}

Fonte: Elaboração própria 


\subsection{CUSTO EVITADO E VALOR TOTAL DO MERCADO PARA LEILÃO}

Conhecendo o modo como se distribui o consumo de energia elétrica através dos diferentes setores e escalas de potência, assumindo uma tarifa média de $329 \mathrm{R} \$ / M W h$ para a indústria em 2010 (ANEEL, 2011), é possível calcular o custo anual evitado que a substituição por motores de alto rendimento proporciona, tanto por setor industrial como por escala de potência. Os resultados obtidos, segmentados como na seção 7.7, apresentam-se nas Tabelas 7.8.1 e 7.8.2 para substituições por avaria, 7.8.5 e 7.8.6 para os motores que entram em funcionamento, e 7.8.9 e 7.8.10 para o total do parque industrial.

\begin{tabular}{|c|c|c|c|c|c|c|c|c|}
\hline Setor & 1.5 & $6-20$ & 21.50 & $51-100$ & $101-200$ & 201.500 & $501+$ & Total \\
\hline Alimentos e bebidas & $3.400,27$ & 698,50 & 73,86 & 42,08 & 23,41 & 1,34 & 86,64 & $4.326,10$ \\
\hline Não ferrosos & 784,98 & 201,18 & 50,27 & 19,25 & 33,21 & 1,26 & 89,97 & $1.180,12$ \\
\hline Ferro-gusa e aço & $1.072,95$ & 275,08 & 68,74 & 26,35 & 45,52 & 1,75 & 123,09 & $1.613,47$ \\
\hline Mineração e pelotização & 654,45 & 167,79 & 41,96 & 16,01 & 27,81 & 1,05 & 75,08 & 984,15 \\
\hline Outros & $9.181,84$ & $2.748,61$ & 223,58 & 70,04 & 54,93 & 1,46 & 72,87 & $12.353,33$ \\
\hline
\end{tabular}

Fonte: Elaboração própria

\begin{tabular}{|c|c|c|c|c|c|c|c|c|}
\hline Setor & 1.5 & $6-20$ & 21.50 & $51-100$ & $101-200$ & 201.500 & $501+$ & Total \\
\hline Alimentos e bebidas & $5.101,06$ & $1.047,87$ & 110,82 & 63,14 & 35,11 & 2,01 & 129,98 & $6.489,98$ \\
\hline Não ferrosos & $1.176,74$ & 301,64 & 75,46 & 28,93 & 49,59 & 1,90 & 134,81 & $1.769,07$ \\
\hline Ferro-gusa e aço & $1.612,02$ & 413,20 & 103,38 & 39,61 & 68,12 & 2,62 & 184,80 & $2.423,75$ \\
\hline Mineração e pelotização & 980,47 & 251,32 & 62,89 & 24,14 & 41,49 & 1,59 & 112,45 & $1.474,35$ \\
\hline Outros & $13.772,78$ & $4.122,96$ & 335,39 & 105,12 & 82,43 & 2,19 & 109,30 & $18.530,17$ \\
\hline
\end{tabular}

Fonte: Elaboração própria

Num leilão, por razões óbvias, o preço da energia economizada vendida será necessariamente bem inferior à tarifa média praticada. No entanto, assumindo um preço para o leilão de 110 R\$/MWh (Garcia, 2008), o valor do mercado de substituição de motores aplicado ao leilão pode ser determinado 
através do mesmo método utilizado para calcular o custo evitado. Pode-se assim identificar as melhores oportunidades, e descobrir onde estão situadas as melhores oportunidades no que toca à troca de motores, por setor industrial e categoria de potência. Os resultados obtidos apresentam-se nas Tabelas 7.8.3 e 7.8.4 para substituições por avaria, 7.8.7 e 7.8.8 para os motores que entram em funcionamento, e 7.8.11 e 7.8.12 para o total do parque industrial.

Tabela 7.8.3 - Estimativa do valor total para o leilấo dos motores a substituir por avaria anualmente, por setor e classe de potência (cenário mínimo, em milhares de $\mathrm{R} \$$ )

\begin{tabular}{|c|c|c|c|c|c|c|c|c|}
\hline \multirow[b]{2}{*}{ Setor } & \multicolumn{8}{|c|}{ Potência (CV) } \\
\hline & $1-5$ & $6-20$ & $21-50$ & $51-100$ & $101-200$ & 201.500 & $501+$ & Total \\
\hline Alimentos e bebidas & $1.136,87$ & 233,54 & 24,69 & 14,07 & 7,83 & 0,45 & 28,97 & $1.446,42$ \\
\hline Papel e celulose & 180,09 & 55,00 & 22,68 & 16,06 & 9,50 & 0,86 & 31,48 & 315,67 \\
\hline Não ferrosos & 262,45 & 67,26 & 16,81 & 6,44 & 11,10 & 0,42 & 30,08 & 394,57 \\
\hline Mineração e pelotização & 218,81 & 56,10 & 14,03 & 5,35 & 9,30 & 0,35 & 25,10 & 329,05 \\
\hline Outros & $3.069,92$ & 918,99 & 74,75 & 23,42 & 18,37 & 0,49 & 24,36 & $4.130,29$ \\
\hline
\end{tabular}

Fonte: Elaboração própria

Porém, para a obtenção de uma estimativa da dimensão do mercado, deve-se também considerar a quantidade de motores que entram na indústria através de equipamentos comprados a OEMs. Estima-se que cerca de $70 \%$ dos motores de indução trifásicos vendidos no Brasil se destinam a OEMs (Soares, 2008), para posterior revenda dos mesmos como parte de outros equipamentos. Provavelmente, a tomada de decisão no que toca à reparação ou substituição de motores inseridos em equipamentos OEM processar-se-á de modo diverso ao que sucede com motores comprados diretamente ao fabricante, pelo que parâmetros como taxa de reparação ou viabilidade de substituição por motores mais eficientes podem ser bem diferentes. Estas diferenças não foram ainda estudadas, e como tal representam uma limitação do atual modelo. Deste modo, considerou-se necessário adotar um fator que represente a porcentagem de motores inseridos em equipamentos vendidos por OEMs que não permitem ou justificam a troca por motores mais eficientes. 
Tabela 7.8.4 - Estimativa do valor total para o leilấo dos motores a substituir por avaria anualmente, por setor e classe de potência (cenário máximo, em milhares de $\mathbf{\text { \$) }}$

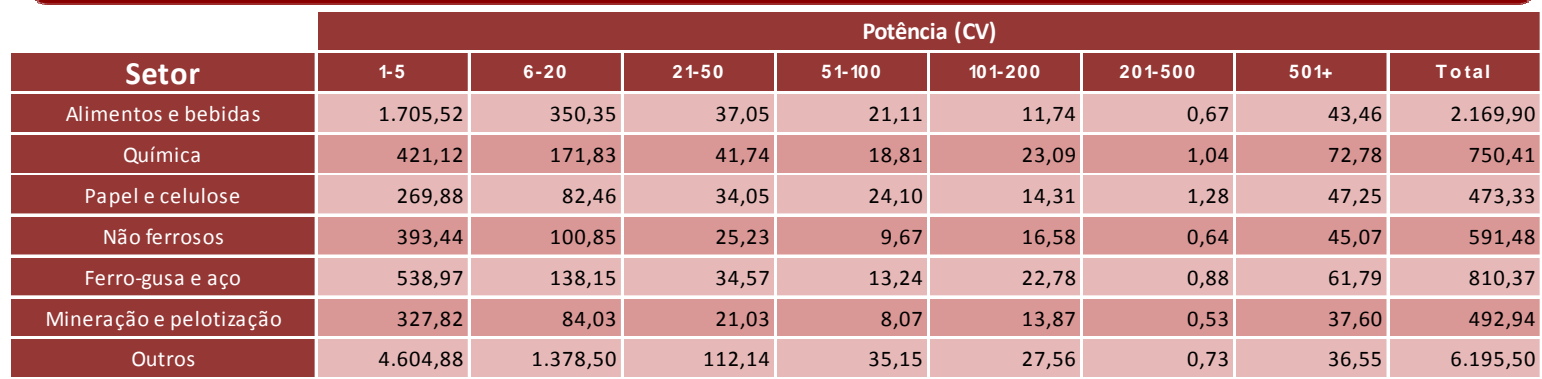

Fonte: Elaboração própria

Outro aspecto que não deve ser esquecido é o fato de, no modelo utilizado, apenas se ter utilizado valores médios para parâmetros como a carga ou o tempo de operação anual. No entanto, pode-se assumir com bastante segurança que, considerando o conjunto de motores que compõem um setor ou uma indústria, nem todos apresentarão parâmetros de operação idênticos à média. Por consequência, para compensar esta limitação do modelo, deve-se utilizar um fator que estime a porcentagem de motores cujo regime de operação se encontra numa faixa que não justifica a substituição (p.ex.: horas de operação anuais insuficientes). Caso se conhecesse o desvio-padrão da distribuição por, por exemplo, tempo de operação ou carga, poder-se-ia ter uma estimativa bastante aproximada a real do fator a utilizar.

Por falta de tais dados, o ideal seria utilizar um valor conservador de modo a não se correr o risco de sobrevalorizar a potencial dimensão do mercado.

Tabela 7.8.5 - Estimativa do custo evitado com motores a entrar em funcionamento anualmente, por setor e classe de potência (cenário mínimo, em milhares de $\mathbf{R} \$$ )

\begin{tabular}{|c|c|c|c|c|c|c|c|c|}
\hline & \multicolumn{8}{|c|}{ Potência (CV) } \\
\hline Setor & 1.5 & $6-20$ & 21.50 & $51-100$ & $101-200$ & 201.500 & $501+$ & Total \\
\hline Alimentos e bebidas & $2.346,19$ & 988,65 & 268,21 & 290,36 & 239,35 & 13,69 & 885,65 & $5.032,09$ \\
\hline Química & 579,62 & 485,13 & 302,23 & 258,97 & 469,84 & 21,31 & $1.483,41$ & $3.600,50$ \\
\hline Papel e celulose & 371,65 & 232,84 & 246,38 & 331,39 & 290,57 & 26,19 & 962,42 & $2.461,44$ \\
\hline Não ferrosos & 541,63 & 284,75 & 182,57 & 132,82 & 339,52 & 12,87 & 919,67 & $2.413,84$ \\
\hline Ferro-gusa e aço & 740,34 & 389,34 & 249,62 & 181,79 & 465,33 & 17,88 & $1.258,28$ & $3.302,57$ \\
\hline Mineração e pelotização & 451,57 & 237,48 & 152,37 & 110,44 & 284,30 & 10,77 & 767,49 & $2.014,42$ \\
\hline Outros & $6.335,47$ & $3.890,34$ & 811,93 & 483,30 & 561,52 & 14,94 & 744,86 & $12.842,36$ \\
\hline
\end{tabular}

Fonte: Elaboração própria 
Tabela 7.8.6 - Estimativa do custo evitado com motores a entrar em funcionamento anualmente, por setor e classe de potência (cenário máximo, em milhares de R\$)

\begin{tabular}{|c|c|c|c|c|c|c|c|c|}
\hline Setor & \multicolumn{8}{|c|}{ Potência (CV) } \\
\hline Alimentos e bebidas & $3.519,73$ & $1.483,13$ & 402,46 & 435,67 & 358,94 & 20,51 & $1.328,64$ & $7.549,08$ \\
\hline Papel e celulose & 556,96 & 349,10 & 369,83 & 497,34 & 437,52 & 39,18 & $1.444,54$ & $3.694,47$ \\
\hline Não ferrosos & 811,95 & 426,93 & 274,05 & 199,61 & 506,94 & 19,42 & $1.378,07$ & $3.616,97$ \\
\hline Mineração e pelotização & 676,53 & 355,71 & 228,39 & 166,56 & 424,07 & 16,26 & $1.149,48$ & $3.017,01$ \\
\hline Outros & $9.503,22$ & $5.835,57$ & $1.217,98$ & 725,32 & 842,66 & 22,37 & $1.117,34$ & $19.264,46$ \\
\hline
\end{tabular}

Fonte: Elaboração própria

Tabela 7.8.7 - Estimativa do valor total para o leilấo dos motores a entrar em

funcionamento anualmente, por setor e classe de potência (cenário mínimo, em milhares de $\mathbf{R} \$$ )

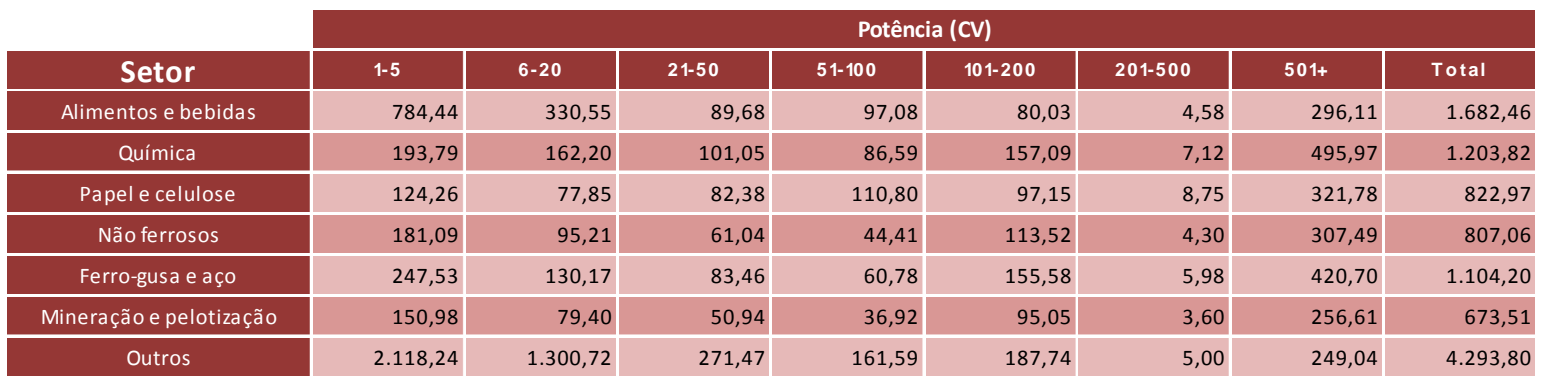

Fonte: Elaboração própria

\begin{tabular}{|c|c|c|c|c|c|c|c|c|}
\hline \multicolumn{9}{|c|}{$\begin{array}{c}\text { Tabela } 7.8 .8 \text { - Estimativa do valor total para o leilão dos motores a entrar em } \\
\text { funcionamento anualmente, por setor e classe de potência (cenário máximo, em milhares } \\
\text { de } \mathbf{R} \$ \text { ) }\end{array}$} \\
\hline & \multicolumn{8}{|c|}{ Potência (CV) } \\
\hline Setor & 1.5 & $6-20$ & 21.50 & $51-100$ & $101-200$ & 201.500 & $501+$ & Total \\
\hline Alimentos e bebidas & $1.176,81$ & 495,88 & 134,56 & 145,66 & 120,01 & 6,86 & 444,23 & $2.524,01$ \\
\hline Química & 290,57 & 243,21 & 151,57 & 129,78 & 235,99 & 10,68 & 743,98 & $1.805,78$ \\
\hline Papel e celulose & 186,22 & 116,72 & 123,65 & 166,29 & 146,28 & 13,10 & 482,98 & $1.235,23$ \\
\hline Não ferrosos & 271,47 & 142,74 & 91,63 & 66,74 & 169,49 & 6,49 & 460,75 & $1.209,32$ \\
\hline Ferro-gusa e aço & 371,89 & 195,54 & 125,53 & 91,38 & 232,83 & 8,95 & 631,59 & $1.657,71$ \\
\hline Mineração e pelotização & 226,19 & 118,93 & 76,36 & 55,69 & 141,79 & 5,44 & 384,32 & $1.008,73$ \\
\hline Outros & $3.177,37$ & $1.951,10$ & 407,23 & 242,51 & 281,74 & 7,48 & 373,58 & $6.441,00$ \\
\hline
\end{tabular}

Fonte: Elaboração própria 
Tabela 7.8.9 - Estimativa do custo evitado potencial existente no parque industrial brasileiro, por setor e classe de potência (cenário mínimo, em milhares de R\$)

\begin{tabular}{|c|c|c|c|c|c|c|c|c|}
\hline & \multicolumn{8}{|c|}{ Potência (CV) } \\
\hline Setor & $1-5$ & $6-20$ & 21.50 & $51-100$ & $101-200$ & 201.500 & $501+$ & Total \\
\hline Alimentos e bebidas & $59.655,51$ & $21.492,35$ & $5.830,69$ & $6.312,10$ & $5.203,32$ & 297,58 & $19.253,22$ & $109.393,29$ \\
\hline Papel e celulose & $8.079,41$ & $5.061,70$ & $5.356,13$ & $7.204,07$ & $6.316,71$ & 569,24 & $20.922,20$ & $53.509,46$ \\
\hline Não ferrosos & $11.774,65$ & $6.190,23$ & $3.968,91$ & $2.887,40$ & $7.380,85$ & 279,87 & $19.992,90$ & $52.474,80$ \\
\hline Outros & $137.727,60$ & $84.572,66$ & $17.650,68$ & $10.506,54$ & $12.206,95$ & 324,83 & $16.192,54$ & $279.181,80$ \\
\hline
\end{tabular}

Fonte: Elaboração própria

\begin{tabular}{|c|c|c|c|c|c|c|c|c|}
\hline & \multicolumn{8}{|c|}{ Potência (CV) } \\
\hline Setor & 1.5 & $6-20$ & 21.50 & $51-100$ & $101-200$ & 201.500 & $501+$ & Total \\
\hline Alimentos e bebidas & $76.515,84$ & $32.242,06$ & $8.749,06$ & $9.471,01$ & $7.803,11$ & 445,84 & $28.883,42$ & $164.110,34$ \\
\hline Química & $18.893,04$ & $15.813,39$ & $9.855,08$ & $8.438,16$ & $15.343,89$ & 694,43 & $48.373,56$ & $117.411,55$ \\
\hline Papel e celulose & $12.107,93$ & $7.589,05$ & $8.039,69$ & $10.811,83$ & $9.511,21$ & 851,80 & $31.402,95$ & $80.314,46$ \\
\hline Não ferrosos & $17.651,09$ & $9.281,17$ & $5.957,59$ & $4.339,35$ & $11.020,49$ & 422,18 & $29.957,97$ & $78.629,85$ \\
\hline Ferro-gusa e aço & $24.180,26$ & $12.714,00$ & $8.161,87$ & $5.941,75$ & $15.138,55$ & 581,79 & $41.065,65$ & $107.783,86$ \\
\hline Mineração e pelotização & $14.707,11$ & $7.732,93$ & $4.965,05$ & $3.620,78$ & $9.219,00$ & 353,55 & $24.988,69$ & $65.587,11$ \\
\hline Outros & $206.591,67$ & $126.860,16$ & $26.477,85$ & $15.767,91$ & $18.318,72$ & 486,23 & $24.289,97$ & $418.792,50$ \\
\hline
\end{tabular}

Fonte: Elaboração própria

Tabela 7.8.11 - Estimativa do valor total para o leilão dos motores existentes no parque industrial brasileiro, por setor e classe de potência (cenário mínimo, em milhares de R\$)

\begin{tabular}{|c|r|r|r|r|r|r|r|r|}
\hline & \multicolumn{9}{|c|}{ Potência (CV) } \\
\hline Setor & \multicolumn{1}{|c|}{$\mathbf{1 - 5}$} & \multicolumn{1}{c|}{$\mathbf{6 - 2 0}$} & \multicolumn{1}{c|}{$\mathbf{2 1 - 5 0}$} & $\mathbf{5 1 - 1 0 0}$ & $\mathbf{1 0 1 - 2 0 0}$ & $\mathbf{2 0 1 - 5 0 0}$ & $\mathbf{5 0 1 +}$ & \multicolumn{1}{c|}{ Total } \\
\hline Alimentos e bebidas & $17.053,02$ & $7.185,89$ & $1.949,47$ & $2.110,43$ & $1.739,71$ & 99,49 & $6.437,25$ & $36.575,26$ \\
\hline Química & $4.212,91$ & $3.526,09$ & $2.196,72$ & $1.882,31$ & $3.414,98$ & 154,89 & $10.782,00$ & $26.169,90$ \\
\hline Papel e celulose & $2.701,32$ & $1.692,36$ & $1.790,80$ & $2.408,66$ & $2.111,97$ & 190,32 & $6.995,26$ & $17.890,70$ \\
\hline Não ferrosos & $3.936,81$ & $2.069,68$ & $1.326,99$ & 965,39 & $2.467,76$ & 93,57 & $6.684,56$ & $17.544,77$ \\
\hline Ferro-gusa e aço & $5.381,05$ & $2.829,87$ & $1.814,32$ & $1.321,33$ & $3.382,19$ & 129,97 & $9.145,68$ & $24.004,42$ \\
\hline Mineração pelotização & $3.282,21$ & $1.726,12$ & $1.107,49$ & 802,72 & $2.066,37$ & 78,26 & $5.578,45$ & $14.641,61$ \\
\hline Outros & $46.048,74$ & $28.276,57$ & $5.901,44$ & $3.512,82$ & $4.081,35$ & 108,61 & $5.413,92$ & $93.343,46$ \\
\hline
\end{tabular}

Fonte: Elaboração própria

Tabela 7.8.12 - Estimativa do valor total para o leilấo dos motores existentes no parque industrial brasileiro, por setor e classe de potência (cenário máximo, em milhares de R\$)

\begin{tabular}{|c|r|r|r|r|r|r|r|r|}
\hline & \multicolumn{9}{|c|}{ Potência (CV) } \\
\hline Setor & \multicolumn{1}{|c|}{$\mathbf{1 - 5}$} & \multicolumn{1}{c|}{$\mathbf{6 - 2 0}$} & \multicolumn{1}{c|}{$\mathbf{2 1 - 5 0}$} & $\mathbf{5 1 - 1 0 0}$ & $\mathbf{1 0 1 - 2 0 0}$ & $\mathbf{2 0 1 - 5 0 0}$ & $\mathbf{5 0 1 +}$ & \multicolumn{1}{c|}{ Total } \\
\hline Alimentos e bebidas & $25.582,80$ & $10.780,02$ & $2.925,22$ & $3.166,60$ & $2.608,94$ & 149,07 & $9.657,07$ & $54.869,72$ \\
\hline Química & $6.316,82$ & $5.287,15$ & $3.295,01$ & $2.821,27$ & $5.130,18$ & 232,18 & $16.173,53$ & $39.256,14$ \\
\hline Papel e celulose & $4.048,24$ & $2.537,37$ & $2.688,04$ & $3.614,90$ & $3.180,04$ & 284,80 & $10.499,47$ & $26.852,86$ \\
\hline Não ferrosos & $5.901,58$ & $3.103,13$ & $1.991,90$ & $1.450,85$ & $3.684,66$ & 141,16 & $10.016,34$ & $26.289,62$ \\
\hline Ferro-gusa e aço & $8.084,58$ & $4.250,88$ & $2.728,89$ & $1.986,60$ & $5.061,52$ & 194,52 & $13.730,16$ & $36.037,16$ \\
\hline Mineração e pelotização & $4.917,27$ & $2.585,48$ & $1.660,05$ & $1.210,60$ & $3.082,34$ & 118,21 & $8.354,88$ & $21.928,82$ \\
\hline Outros & $69.073,20$ & $42.415,25$ & $8.852,78$ & $5.271,94$ & $6.124,80$ & 162,57 & $8.121,26$ & $140.021,81$ \\
\hline
\end{tabular}

Fonte: Elaboração própria 


\subsection{EMISSÕES DE $\mathrm{CO}_{2}$ EVITADAS E VALOR POTENCIAL EM CRÉDITOS DE $\mathrm{CO}_{2}$}

Utilizando as estimativas para o potencial de economia existente com a troca de motores na indústria, pode-se assim estimar o potencial de economia em emissões de $\mathrm{CO}_{2}$. Para tal, é necessário conhecer qual a quantidade de emissões de $\mathrm{CO}_{2}$ que corresponde ao consumo de energia elétrica.

Após pesquisa, vários valores foram encontrados para o grau de emissões de $\mathrm{CO}_{2}$ por kWh, como se pode visualizar na Tabela 7.10.1. Dependendo da matriz energética de cada país, o grau de emissões por kWh irá necessariamente variar. Em geral, quanto maior a participação de energias renováveis, menor será o nível de emissões. Para países como o Reino Unido, cuja matriz energética é bem menos dependente de energias renováveis que o Brasil, atualmente o valor é aproximadamente de $0,48 \mathrm{Kg}$ de $\mathrm{CO}_{2}$ por kWh.

Tabela 7.9.1 - Nível de emissões de $\mathrm{CO}_{2}$ por unidade de energia consumida ( $\mathrm{KgCO} 2 /$ kWh)

\begin{tabular}{|c|c|}
\hline Fonte & $\begin{array}{c}\text { Nivel de emissões por unidade de energia } \\
\text { consumida }\left(\mathrm{KgCO}_{2} / \mathbf{k W h}\right)\end{array}$ \\
\hline sunearthtools.com & 0,088854 \\
\hline net.org.uk & 0,09766 \\
\hline iniciativaverde.org.br & 0,5808 \\
\hline
\end{tabular}

Fonte: Elaboração própria, com base nas fontes citadas 
Deste modo, dada a dispersão entre alguns dos valores encontrados, resolveu-se assumir que no Brasil os valores serão bem mais baixos. Como tal, serão bem mais realísticos os dois valores mais baixos que foram encontrados, pelo que serão estes os utilizados.

Os resultados obtidos para o potencial de emissões de $\mathrm{CO}_{2}$ evitadas podem ser visualizados nas Tabelas 7.9.1 e 7.9.2 para substituições por avaria, 7.9.3 e 7.9.4 para os motores que entram em funcionamento, e 7.9.5 e 7.9.6 para

Tabela 7.9. 2- Estimativa do potencial de emissốes evitadas de $\mathrm{CO}_{2} \mathrm{com}$ motores a substituir pır avaria anualmente, por setor e classe de potência (cenário mínimo, em toneladas de $\mathrm{CO}_{2}$ )

\begin{tabular}{|c|c|c|c|c|c|c|c|c|}
\hline & \multicolumn{8}{|c|}{ Potência (CV) } \\
\hline Setor & $1-5$ & $6-20$ & $21-50$ & $51-100$ & $101-200$ & 201.500 & $501+$ & Total \\
\hline Alimentos e bebidas & 918,32 & 188,65 & 19,95 & 11,36 & 6,32 & 0,36 & 23,40 & $1.168,36$ \\
\hline Papel e celulose & 145,47 & 44,43 & 18,32 & 12,97 & 7,68 & 0,69 & 25,43 & 254,99 \\
\hline Não ferrosos & 212,00 & 54,33 & 13,58 & 5,20 & 8,97 & 0,34 & 24,30 & 318,72 \\
\hline Ferro-gusa e aço & 289,77 & 74,29 & 18,56 & 7,12 & 12,29 & 0,47 & 33,24 & 435,75 \\
\hline Outros & $2.479,77$ & 742,33 & 60,38 & 18,92 & 14,84 & 0,39 & 19,68 & $3.336,30$ \\
\hline
\end{tabular}

Fonte: Elaboração própria

o total do parque industrial.

Finalmente, de modo a se poder estimar o potencial valor do mercado de créditos de carbono criado com a troca por motores mais eficientes, assumiu-se que um crédito de carbono, equivalente ao direito de emissão de uma tonelada de $\mathrm{CO}_{2}$, terá, com grande probabilidade, um valor entre $25 \mathrm{R} \$$ e $50 \mathrm{R} \$$ (à taxa de câmbio de 2,5 R\$ por €).

O valor potencial do mercado de créditos de carbono criado pela troca de

Tabela 7.93 - Estimativa do potencial de emissões evitadas de $\mathrm{CO}_{2} \mathrm{com}$ motores a substituir pur avaria anualmente, por setor e classe de potência (cenário máximo, em toneladas de $\mathrm{CO}_{2}$ )

\begin{tabular}{|c|c|c|c|c|c|c|c|c|}
\hline \multirow[b]{2}{*}{ Setor } & \multicolumn{8}{|c|}{ Potência (CV) } \\
\hline & $1-5$ & $6-20$ & $21-50$ & $51-100$ & $101-200$ & 201.500 & $501+$ & Total \\
\hline Alimentos e bebidas & $1.377,66$ & 283,00 & 29,93 & 17,05 & 9,48 & 0,54 & 35,10 & $1.752,77$ \\
\hline Papel e celulose & 218,00 & 66,61 & 27,50 & 19,47 & 11,56 & 1,04 & 38,16 & 382,34 \\
\hline Não ferrosos & 317,81 & 81,46 & 20,38 & 7,81 & 13,39 & 0,51 & 36,41 & 477,78 \\
\hline Outros & $3.719,65$ & $1.113,50$ & 90,58 & 28,39 & 22,26 & 0,59 & 29,52 & $5.004,50$ \\
\hline
\end{tabular}

Fonte: Elaboração própria 
motores apresenta-se nas Tabelas 7.9.7 e 7.9.8 para substituições por avaria, 7.9.9 e 7.9.10 para os motores que entram em funcionamento, e 7.9.11 e 7.9.12 para o total do parque industrial.

\begin{tabular}{|c|c|c|c|c|c|c|c|c|}
\hline \multirow[b]{2}{*}{ Setor } & \multicolumn{8}{|c|}{ Potência (CV) } \\
\hline & $1-5$ & $6-20$ & $21-50$ & $51-100$ & $101-200$ & 201.500 & $501+$ & Total \\
\hline Alimentos e bebidas & 633,64 & 267,01 & 72,44 & 78,42 & 64,64 & 3,70 & 239,19 & $1.359,03$ \\
\hline Química & 156,54 & 131,02 & 81,62 & 69,94 & 126,89 & 5,76 & 400,63 & 972,40 \\
\hline Papel e celulose & 100,37 & 62,88 & 66,54 & 89,50 & 78,47 & 7,07 & 259,92 & 664,77 \\
\hline Não ferrosos & 146,28 & 76,90 & 49,31 & 35,87 & 91,69 & 3,48 & 248,38 & 651,91 \\
\hline Ferro-gusa e aço & 199,94 & 105,15 & 67,41 & 49,10 & 125,67 & 4,83 & 339,83 & 891,94 \\
\hline Mineração e pelotização & 121,96 & 64,14 & 41,15 & 29,83 & 76,78 & 2,91 & 207,28 & 544,04 \\
\hline Outros & $1.711,04$ & $1.050,68$ & 219,28 & 130,53 & 151,65 & 4,04 & 201,17 & $3.468,37$ \\
\hline
\end{tabular}

Fonte: Elaboração própria

Tabela 7.9. 5- Estimativa do potencial de emissões evitadas de $\mathrm{CO}_{2}$ dos motores a entrar em funcionamento anualmente, por setor e classe de potência (cenário máximo, em toneladas de $\mathrm{CO}_{2}$ )

\begin{tabular}{|c|c|c|c|c|c|c|c|c|}
\hline & \multicolumn{8}{|c|}{ Potência (CV) } \\
\hline Setor & 1.5 & $6-20$ & 21.50 & $51-100$ & $101-200$ & 201.500 & $501+$ & Total \\
\hline Alimentos e bebidas & 950,58 & 400,55 & 108,69 & 117,66 & 96,94 & 5,54 & 358,83 & $2.038,80$ \\
\hline Papel e celulose & 150,42 & 94,28 & 99,88 & 134,32 & 118,16 & 10,58 & 390,13 & 997,78 \\
\hline Não ferrosos & 219,29 & 115,30 & 74,01 & 53,91 & 136,91 & 5,24 & 372,18 & 976,85 \\
\hline Outros & $2.566,56$ & $1.576,03$ & 328,94 & 195,89 & 227,58 & 6,04 & 301,76 & $5.202,81$ \\
\hline
\end{tabular}

Fonte: Elaboração própria

Tabela 7.9. 6- Estimativa do potencial de emissões evitadas de $\mathrm{CO}_{2}$ no parque industrial brasileiro, por setor e classe de potência (cenário mínimo, em toneladas de $\mathrm{CO}_{2}$ )

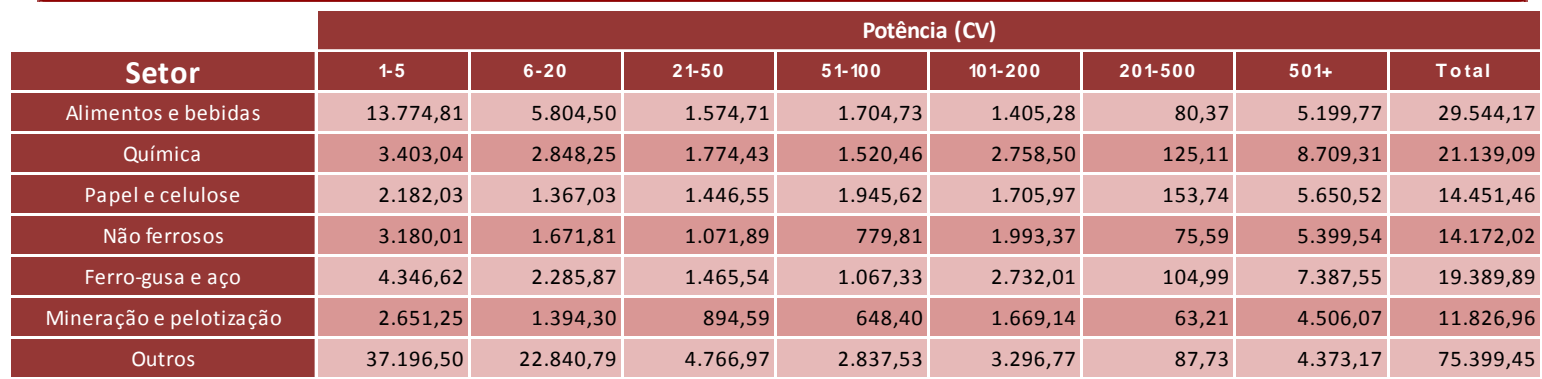

Fonte: Elaboração própria 
Tabela 7.9. 7- Estimativa do potencial de emissões evitadas de $\mathrm{CO}_{2}$ no parque industrial brasileiro, por setor e classe de potência (cenário máximo, em toneladas de $\mathrm{CO}_{2}$ )

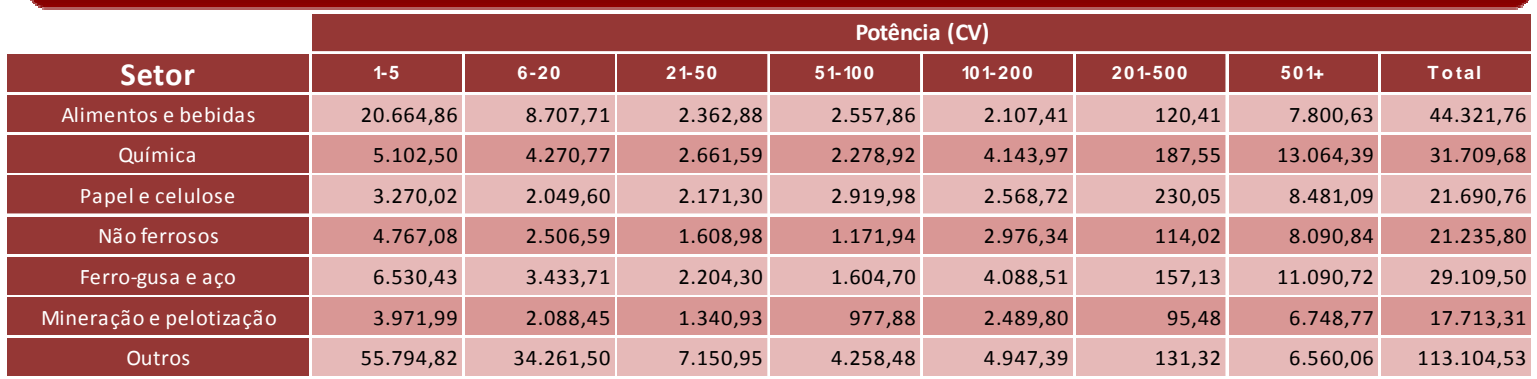

Fonte: Elaboração própria

Tabela 7.98 - Estimativa do valor potencial em créditos de $\mathrm{CO}_{2} \mathrm{com}$ motores a substituir por avaria anualmente, por setor e classe de potência (cenário mínimo, em $\mathbf{R} \$$ )

\begin{tabular}{|c|c|c|c|c|c|c|c|c|}
\hline \multirow[b]{2}{*}{ Setor } & \multicolumn{8}{|c|}{ Potência (CV) } \\
\hline & 1.5 & $6-20$ & 21.50 & $51-100$ & 101.200 & 201.500 & $501+$ & Total \\
\hline Alimentos e bebidas & $22.958,01$ & $4.716,16$ & 498,66 & 284,12 & 158,09 & 9,04 & 584,97 & $29.209,06$ \\
\hline Papel e celulose & $3.636,72$ & $1.110,71$ & 458,07 & 324,27 & 191,92 & 17,30 & 635,68 & $6.374,67$ \\
\hline Não ferrosos & $5.300,02$ & $1.358,35$ & 339,43 & 129,97 & 224,25 & 8,50 & 607,45 & $7.967,98$ \\
\hline Outros & $61.994,17$ & $18.558,14$ & $1.509,54$ & 472,92 & 370,89 & 9,87 & 491,98 & $83.407,50$ \\
\hline
\end{tabular}

Fonte: Elaboração própria

Tabela 7.9. 9- Estimativa do valor potencial em créditos de $\mathrm{CO}_{2} \mathrm{com}$ motores a substituir por avar ra anualmente, por setor e classe de potência (cenário máximo, em $\mathbf{R} \$$ )

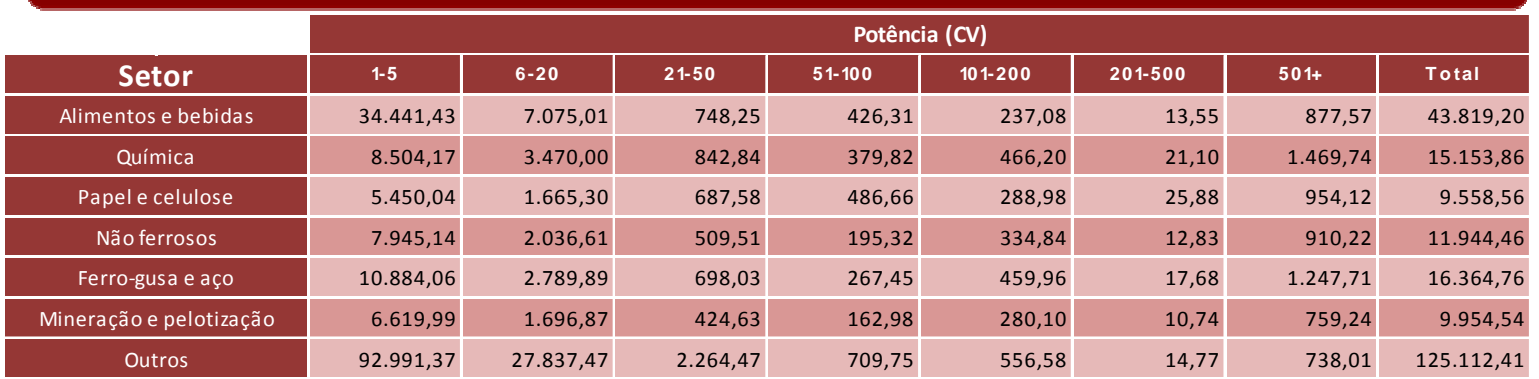

Fonte: Elaboração própria 
Tabela 7.9 10 Estimativa do valor potencial em créditos de $\mathrm{CO}_{2} \mathrm{com}$ motores a entrar em funcionamento anualmente, por setor e classe de potência (cenário mínimo, em $\mathbf{R} \$$ )

\begin{tabular}{|c|r|r|r|r|r|r|r|r|}
\hline & \multicolumn{7}{|c|}{ Potência (CV) } \\
\hline Setor & \multicolumn{1}{|c|}{$\mathbf{1 . 5}$} & \multicolumn{1}{c|}{$\mathbf{6 - 2 0}$} & \multicolumn{1}{c|}{$\mathbf{2 1 - 5 0}$} & $\mathbf{5 1 - 1 0 0}$ & $\mathbf{1 0 1 - 2 0 0}$ & $\mathbf{2 0 1 - 5 0 0}$ & $\mathbf{5 0 1 +}$ & \multicolumn{1}{c|}{ Total } \\
\hline Alimentos e bebidas & $18.528,04$ & $7.807,44$ & $2.118,09$ & $2.292,97$ & $1.890,19$ & 108,10 & $6.994,04$ & $33.975,79$ \\
\hline Química & $5.164,67$ & $4.322,68$ & $2.692,98$ & $2.307,55$ & $4.186,47$ & 189,88 & $13.217,79$ & $24.309,96$ \\
\hline Papel e celulose & $3.293,60$ & $2.063,42$ & $2.183,45$ & $2.936,77$ & $2.575,03$ & 232,05 & $8.529,02$ & $16.619,18$ \\
\hline Não ferrosos & $4.785,66$ & $2.515,94$ & $1.613,11$ & $1.173,55$ & $2.999,86$ & 113,75 & $8.125,87$ & $16.297,83$ \\
\hline Ferro-gusa e aço & $6.541,31$ & $3.440,04$ & $2.205,52$ & $1.606,24$ & $4.111,45$ & 158,00 & $11.117,66$ & $22.298,38$ \\
\hline Mineração e pelotização & $3.989,91$ & $2.098,30$ & $1.346,28$ & 975,80 & $2.511,92$ & 95,13 & $6.781,27$ & $13.601,01$ \\
\hline Outros & $45.248,15$ & $27.784,96$ & $5.798,84$ & $3.451,75$ & $4.010,39$ & 106,72 & $5.319,80$ & $86.709,37$ \\
\hline
\end{tabular}

Fonte: Elaboração própria

Tabela 7.9 .11 - Estimativa do valor potencial em créditos de $\mathrm{CO}_{2} \mathrm{com}$ motores a entrar em funcionaıınto anualmente, por setor e classe de potência (cenário máximo, em R\$)

\begin{tabular}{|c|c|c|c|c|c|c|c|c|}
\hline \multirow[b]{2}{*}{ Setor } & \multicolumn{8}{|c|}{ Potência (CV) } \\
\hline & 1.5 & $6-20$ & $21-50$ & $51-100$ & $101-200$ & $201-500$ & $501+$ & Total \\
\hline Alimentos e bebidas & $27.795,62$ & $11.712,45$ & $3.178,24$ & $3.440,50$ & $2.834,61$ & 161,96 & $10.492,37$ & $50.970,03$ \\
\hline Papel e celulose & $4.935,85$ & $3.093,71$ & $3.277,41$ & $4.407,49$ & $3.877,28$ & 347,24 & $12.801,54$ & $24.944,38$ \\
\hline Não ferrosos & $7.174,07$ & $3.772,22$ & $2.421,39$ & $1.763,68$ & $4.479,14$ & 171,59 & $12.176,05$ & $24.421,17$ \\
\hline Outros & $67.872,32$ & $41.677,83$ & $8.698,86$ & $5.180,29$ & $6.018,32$ & 159,74 & $7.980,07$ & $130.070,21$ \\
\hline
\end{tabular}

Fonte: Elaboração própria

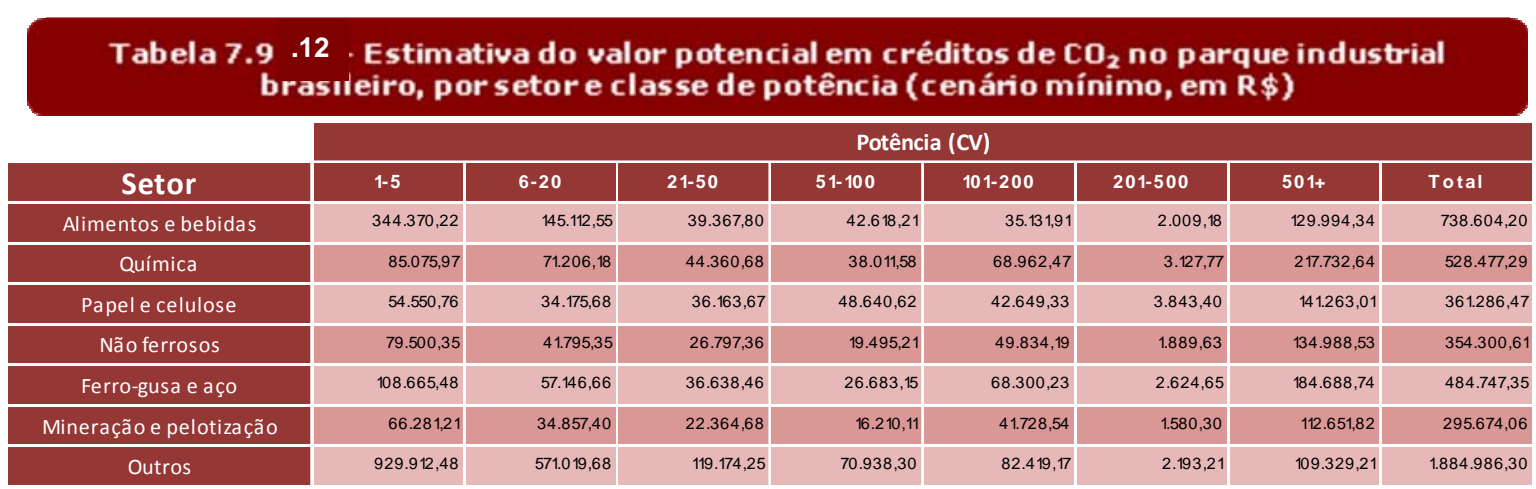

Fonte: Elaboração própria 


\begin{tabular}{|c|c|c|c|c|c|c|c|c|}
\hline & \multicolumn{8}{|c|}{ Potência (CV) } \\
\hline Setor & 1.5 & $6-20$ & 21.50 & $51-100$ & $101-200$ & 201.500 & $501+$ & Total \\
\hline Alimentos e bebidas & $516.621,46$ & $217.692,73$ & $59.072,12$ & $63.946,57$ & $52.685,21$ & $3.010,25$ & $195.015,76$ & $1108.044,11$ \\
\hline Química & $127.562,48$ & $106.769,20$ & $66.539,73$ & $56.972,97$ & $103.599,27$ & $4.688,70$ & $326.609,74$ & $792.742,10$ \\
\hline Não ferrosos & $119.177,05$ & $62.664,83$ & $40.224,59$ & $29.298,52$ & $74.408,42$ & $2.850,52$ & $202.270,95$ & $530.894,89$ \\
\hline Ferro-gusa e aço & $163.260,83$ & $85.842,65$ & $55.107,48$ & $40.117,62$ & $102.212,84$ & $3.928,14$ & $277.268,03$ & $727.737,60$ \\
\hline Mineração e pelotização & $99.299,82$ & $52.211,35$ & $33.523,15$ & $24.446,88$ & $62.245,08$ & $2.387,12$ & $168.719,23$ & $442.832,64$ \\
\hline Outros & $1394.870,56$ & $856.537,42$ & $178.773,77$ & $106.462,12$ & $123.684,75$ & $3.282,97$ & $164.001,56$ & $2.827 .613,15$ \\
\hline
\end{tabular}

Fonte: Elaboração própria 


\section{RESULTADOS OBTIDOS - CONCLUSÕES}

No gráfico 8.10.1 podem-se visualizar os resultados obtidos para o potencial de economia em energia elétrica estimado para cada setor industrial. Tal como é possível observar, o maior potencial de economia na indústria pertence ao conjunto dos setores que não foram estudados em particular neste trabalho devido a falta de dados. Este fato reforça a idéia de que, tendo em conta que estes setores não estudados representam, no total, um valor superior a $40 \%$ do total do potencial de economia na indústria brasileira, será importante proceder a pesquisas que permitam conhecer melhor estes setores, de modo a que se possa estimar o seu consumo separadamente.

Em relação aos restantes setores industriais, estimou-se que os setores de Alimentos e bebidas e Químico são os que apresentam maior potencial.

De modo a se poder ter uma noção da atratividade da troca de motores para cada setor industrial, resolveu-se cruzar os dados existentes relativamente ao consumo particular de cada setor com os intervalos de economia potencial obtidos. Conforme se pode observar na Tabela 8.10.1, o setor de Alimentos e bebidas é aquele cujo potencial de economia obtido através de trocas por motores mais eficientes se apresenta maior - entre 1,34\% e 2,01\%. O potencial de atratividade de cada setor foi estimado conforme se mostra na matriz disposta no Gráfico 8.10.2, na qual o peso do potencial de economia de cada setor é cruzado com a magnitude da própria poupança potencial em consumo de energia. 
Inicialmente, idealizou-se a criação de diversas matrizes, utilizando o também outro tipo de indicadores (p.ex.: custo de parada de produção) de modo a se poder medir várias dimensões do potencial de atratividade, o que não veio a acontecer por falta de dados precisos.

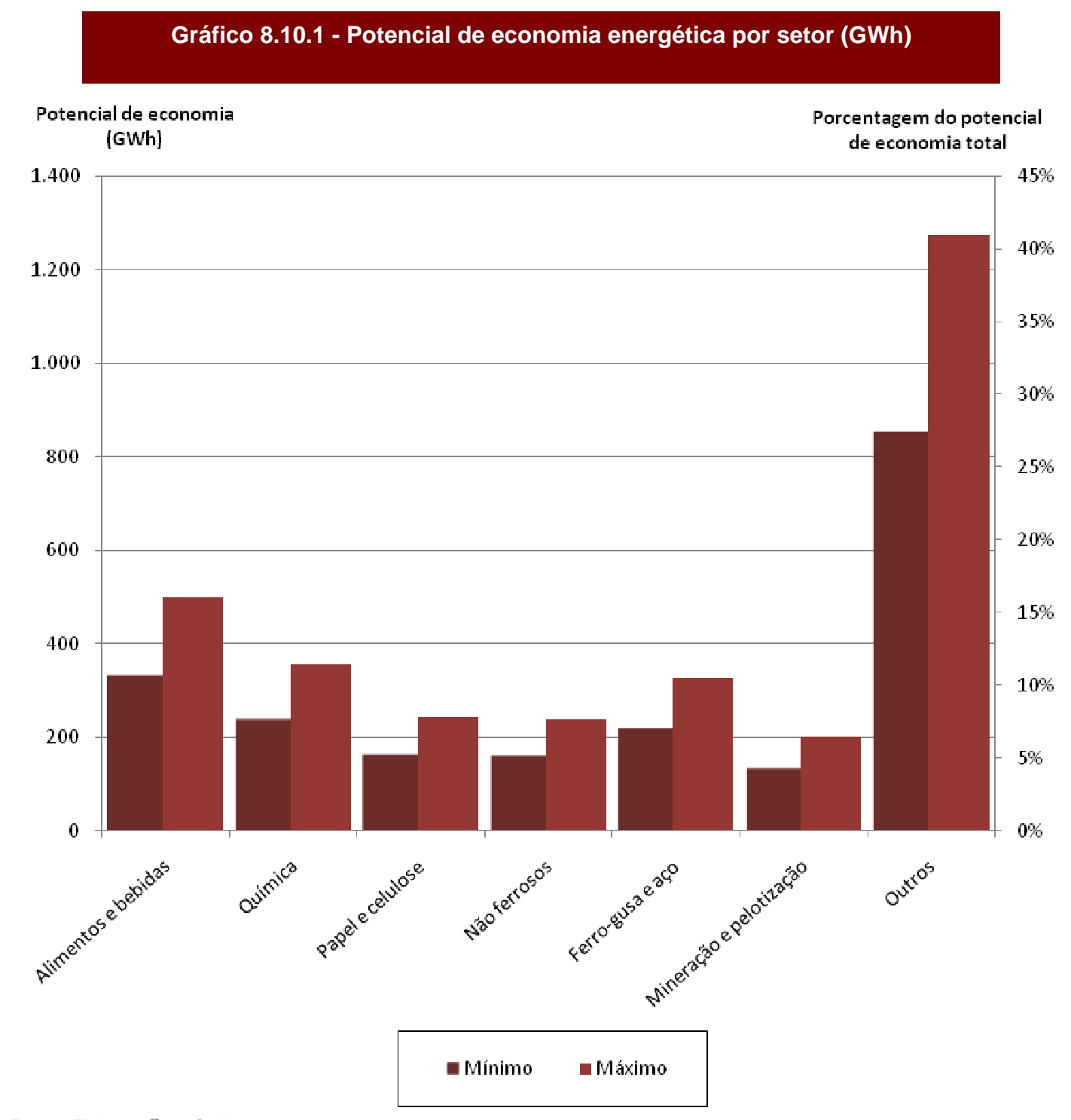

Fonte: Elabora, ão própria

Observando estes números, é possível verificar que uma boa parte do potencial de economia de energia com a troca por motores de alto rendimento na indústria brasileira se encontra nas duas categorias mais baixas de potência, 1 a $5 \mathrm{CV}$ e de 6 a $20 \mathrm{CV}$, como se pode visualizar nas Tabelas 8.10.3 e 8.10.4. 
Tabela 8.10.1 - Peso do potencial de economia energética no consumo de cada setor

\begin{tabular}{|c|c|c|c|c|c|c|}
\hline \multirow[b]{2}{*}{ Setor } & \multirow{2}{*}{$\begin{array}{l}\text { Consumo do } \\
\text { Setor (GWh) }\end{array}$} & \multicolumn{3}{|c|}{ Economia potencial } & \multicolumn{2}{|c|}{$\begin{array}{l}\text { Economia potencial em } \\
\text { porcentagem do consumo } \\
\text { do setor }\end{array}$} \\
\hline & & Mínimo & M áximo & $\%$ total ind. & M ínimo & M áximo \\
\hline Alimentos e bebidas & $24.856,55$ & 332,50 & 498,82 & $15,89 \%$ & $1,34 \%$ & $2,01 \%$ \\
\hline Química & $27.061,59$ & 237,91 & 356,87 & $11,37 \%$ & $0,88 \%$ & $1,32 \%$ \\
\hline Papel e celulose & $17.652,89$ & 162,64 & 244,12 & $7,77 \%$ & $0,92 \%$ & $1,38 \%$ \\
\hline Não ferrosos & $42.456,85$ & 159,50 & 239,00 & $7,62 \%$ & $0,38 \%$ & $0,56 \%$ \\
\hline Ferro-gusa e aço & $21.136,39$ & 218,22 & 327,61 & $10,43 \%$ & $1,03 \%$ & $1,55 \%$ \\
\hline Mineração e pelotização & $11.522,34$ & 133,11 & 199,35 & $6,36 \%$ & $1,16 \%$ & $1,73 \%$ \\
\hline Outros & $70.625,35$ & 848,58 & $1.272,93$ & $40,55 \%$ & $1,20 \%$ & $1,80 \%$ \\
\hline
\end{tabular}

Fonte: Elaboração própria

Embora a categoria correspondente aos motores com mais de $500 \mathrm{CV}$ apresente também um elevado potencial de economia, estima-se que o erro nos resultados obtidos será maior. Isto se deve ao fato de, à falta da existência de dados no BDMotor para motores superiores a $500 \mathrm{CV}$, não ter sido possível estimar o consumo deste segmento na indústria brasileira. Assim, para se poder ter uma noção do consumo deste segmento, foram utilizados os dados correspondentes ao consumo porcentual dos motores com mais de $500 \mathrm{CV}$ na indústria americana. Como a indústria norte-americana aparenta possuir uma maior porcentagem de motores com elevada potência, é, por consequência, bem possível que estes dados estejam sobreestimados.

Estimou-se o potencial total de economia de energia no atual parque industrial de motores através da troca por motores de alto rendimento como estando entre cerca de 2 e $3 \mathrm{GWh} / a n o$. Esta estimativa significa que, apenas através da troca de motores standard por motores de alto rendimento, o potencial de economia em relação ao consumo total de energia elétrica andará entre 1 a $1,5 \%$. No que respeita ao consumo total de energia elétrica em força motriz na indústria, a economia equivalerá a entre 2 a 3\%. 
O mercado de substituição de motores por avaria é um pouco inferior ao mercado de motores a entrar em funcionamento, estimando-se que o seu valor anual num eventual leilão de eficiência energética esteja entre aproximadamente 7,7 e 11,5 milhões de reais, como se pode verificar na Tabela 8.10.2. Por sua vez, o mercado de motores que entram em funcionamento valerá entre $R \$ 10,6$ e $\mathrm{R} \$ 15,9$ milhões anualmente. Ambos estes valores são naturalmente bem inferiores ao potencial total do atual parque industrial de motores, o qual se estima poder valer entre 230,2 e 345,3 milhões de reais.

\section{Gráfico 8.10.2 - Análise de atratividade de cada setor}

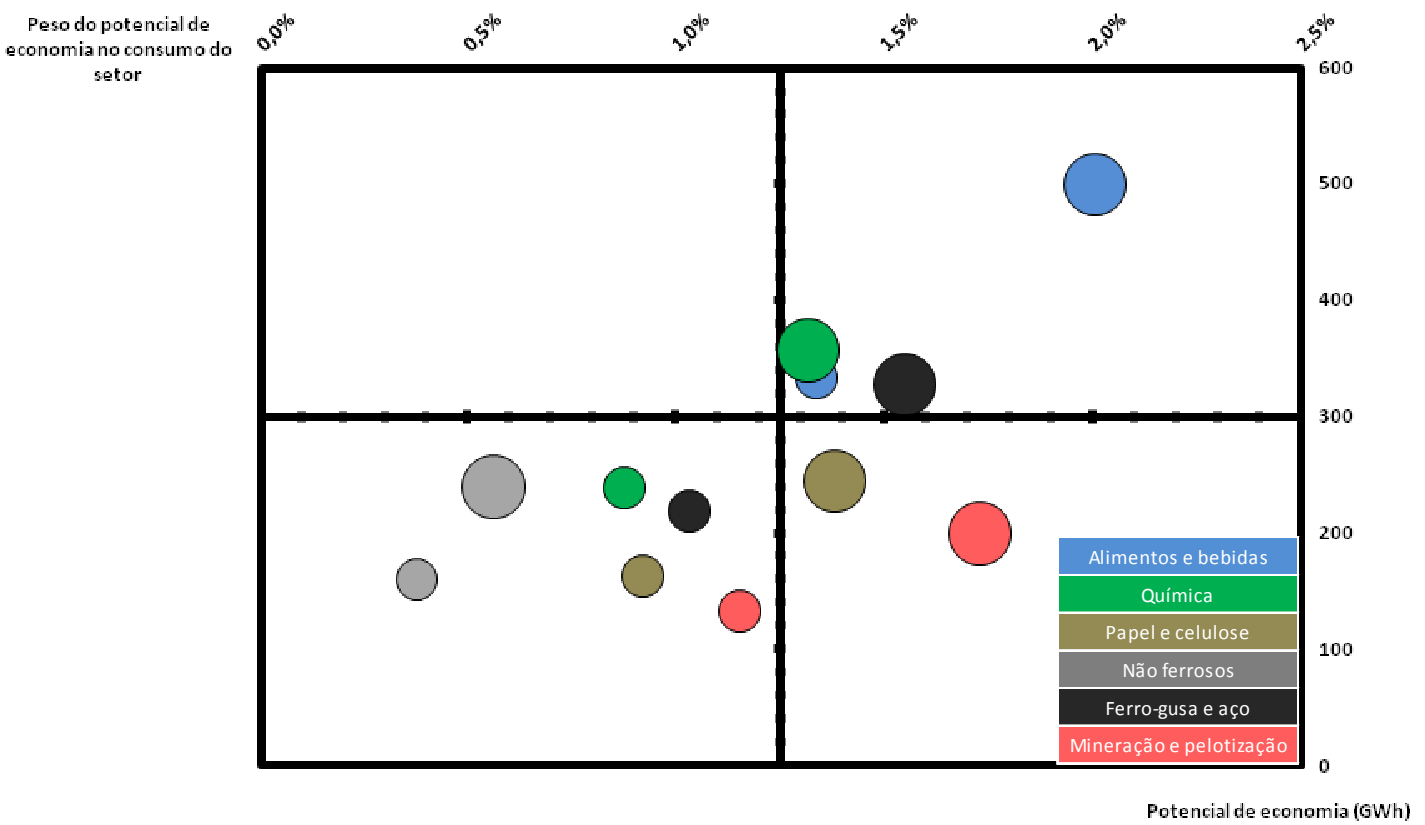

Fonte: Elabora, ão própria

Neste gráfico, foi demonstrado a atratividade máxima representado pelos círculos maiores e a atratividade mínima, representada pelos círculos menores para cada setor destacado pelas cores dos círculos e pelo setor destacado. A idéia foi a de mostrar de forma simplificada qual a geração de valor máxima e mínima por setor de consumo, que cada uso final representa para a dados seu potencial de economia pelo peso do potencial de economia no setor.

Em relação às emissões evitadas de $\mathrm{CO}_{2}$, prevê-se que o valor em créditos no mercado de carbono possa equivaler a cerca de $2 \%$ do valor da energia economizada em leilão, assumindo um preço igual a $110 \mathrm{R} \$ / \mathrm{MWh}$. 


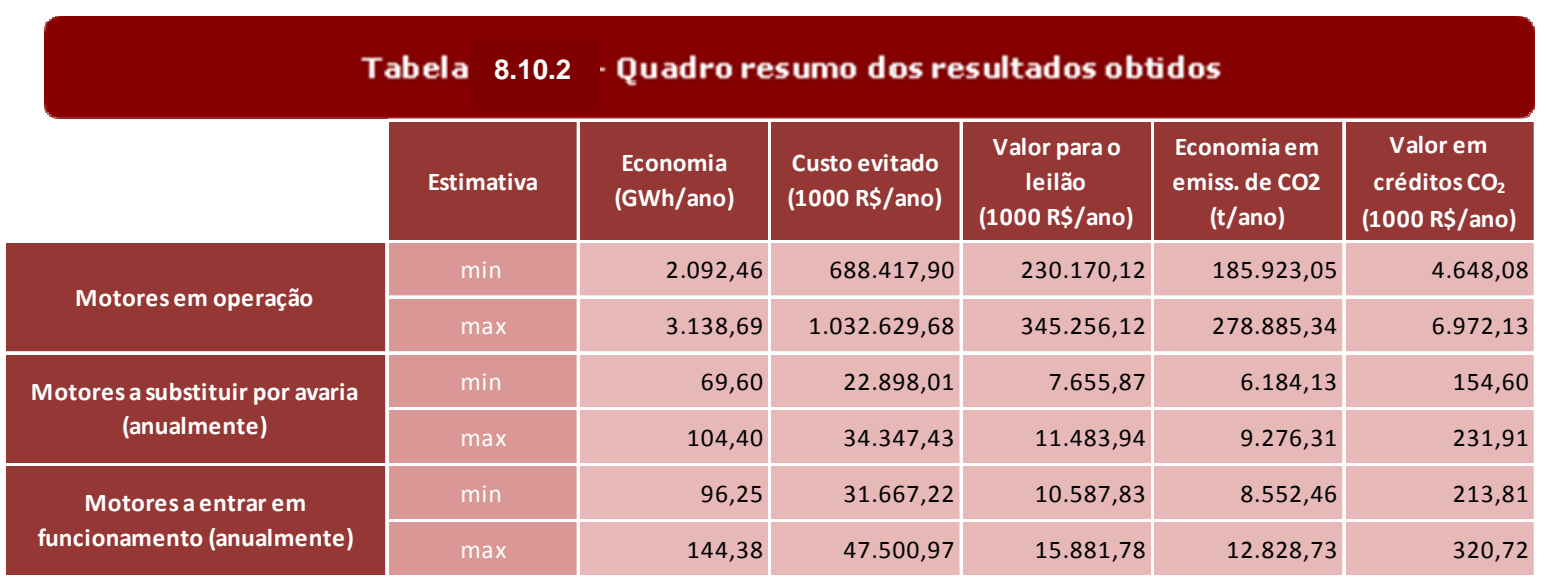

Fonte: Elaboração própria

Pode-se também constatar que o potencial de economia anual com a substituição de motores que avariam também é significativo. Neste caso, a concentração do potencial ainda é maior nas categorias mais baixas, sendo que $70 \%$ corresponde a escala de 1 a $5 \mathrm{CV}$. Mais de $90 \%$ do potencial total encontrase em motores de 20 CV ou menos (Tabela 8.10.3). Em relação ao potencial com as entradas de motores em funcionamento anualmente devido à expansão do parque industrial de motores, a maioria do potencial de economia também se encontra na categoria mais baixa, embora de forma menos concentrada que na substituição de motores. De fato, enquanto que para a categoria de 1 a 5 CV o potencial de economia de substituição por avaria é bem superior ao potencial com motores que entram em funcionamento, em todas as restantes categorias

Tabela 8.10.3 - Potencial de economia de energia elétrica com motores a substituir por avarıa anualmente em cada setor, distribuido por classe de potência

\begin{tabular}{|c|c|c|c|c|c|c|c|c|}
\hline & \multicolumn{8}{|c|}{ Potência (CV) } \\
\hline Setor & 1.5 & $6-20$ & 21.50 & $51-100$ & $101-200$ & 201.500 & $501+$ & Total \\
\hline Alimentos e bebidas & $78,60 \%$ & $16,15 \%$ & $1,71 \%$ & $0,97 \%$ & $0,54 \%$ & $0,03 \%$ & $2,00 \%$ & $100,00 \%$ \\
\hline Química & $56,13 \%$ & $22,90 \%$ & $5,56 \%$ & $2,51 \%$ & $3,07 \%$ & $0,14 \%$ & $9,70 \%$ & $100,00 \%$ \\
\hline Papel e celulose & $57,05 \%$ & $17,42 \%$ & $7,19 \%$ & $5,09 \%$ & $3,01 \%$ & $0,27 \%$ & $9,97 \%$ & $100,00 \%$ \\
\hline Não ferrosos & $66,52 \%$ & $17,05 \%$ & $4,26 \%$ & $1,63 \%$ & $2,81 \%$ & $0,11 \%$ & $7,62 \%$ & $100,00 \%$ \\
\hline Ferro-gusa e aço & $66,50 \%$ & $17,05 \%$ & $4,26 \%$ & $1,63 \%$ & $2,82 \%$ & $0,11 \%$ & $7,63 \%$ & $100,00 \%$ \\
\hline Mineração e pelotização & $66,50 \%$ & $17,05 \%$ & $4,26 \%$ & $1,63 \%$ & $2,83 \%$ & $0,11 \%$ & $7,63 \%$ & $100,00 \%$ \\
\hline Outros & $74,33 \%$ & $22,25 \%$ & $1,81 \%$ & $0,57 \%$ & $0,44 \%$ & $0,01 \%$ & $0,59 \%$ & $100,00 \%$ \\
\hline Total & $71,94 \%$ & $20,08 \%$ & $2,66 \%$ & $1,13 \%$ & $1,13 \%$ & $0,05 \%$ & $3,00 \%$ & $100,00 \%$ \\
\hline
\end{tabular}


ocorre exatamente o inverso, como se pode verificar nas Tabelas 8.10.3 e 8.10.4. Há que salientar que os motores que entram em funcionamento apresentam uma distribuição idêntica aos dados obtidos para o conjunto dos motores atualmente em operação na indústria. Isto se deve ao fato de se ter calculado o número de motores que entram em funcionamento como função direta tanto do crescimento do consumo de energia elétrica na indústria, como da sua composição estimada por escalas de potência.

É importante destacar que estes valores foram estimados para o ano de 2010. Com o crescimento previsto da economia brasileira e consequente expansão do parque industrial de motores, mesmo com uma penetração crescente de motores de alto rendimento, prevê-se que estes valores venham a aumentar. Deste modo, seria interessante descobrir a que ritmo tem evoluído a penetração de motores de alto rendimento no parque industrial brasileiro.

Tabela 8.10.4 Potencial de economia de energia elétrica com motores atualmente em operaçấo em cada setor, distribuído por classe de potência

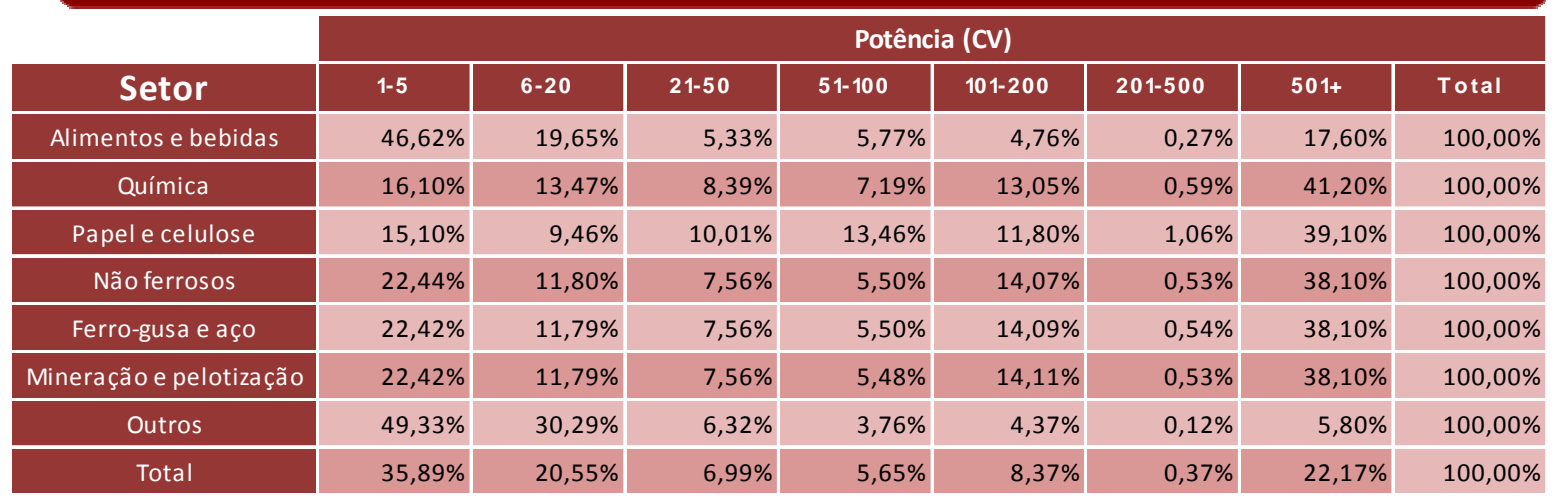

Fonte: Elaboração própria

Conhecendo essa informação, seria possível extrapolar a sua evolução ao longo dos próximos anos. Cruzando estes dados com a expansão do parque industrial brasileiro de motores e dimensões dos mercados de substituição e entrada de motores em funcionamento, poder-se-á então ter uma noção do quanto irão realmente crescer estes dois segmentos nos próximos anos. 


\subsection{Implementação deste trabalho - Linha de atuação}

Ao se analisar o modelo criado e os vários resultados obtidos, algumas considerações devem ser feitas, tendo em vista uma eventual futura implementação dos leilões de eficiência energética. Assim, com vista a melhorar a precisão do modelo e tornar as diversas estimativas mais exatas, descrevem-se a seguir algumas das direções que se consideram interessantes num contexto de pesquisa e desenvolvimento.

\subsubsection{Distribuição de motores por escala de potência}

Como os dados existentes atualmente sobre a composição do parque industrial de motores no Brasil são bastante limitados, teve de se recorrer a extrapolações em relação a praticamente todos os dados utilizados no modelo utilizado.

Deste modo, em primeiro lugar, seria importante obter uma boa estimativa da distribuição exata de motores por escala de potência através dos diferentes setores industriais. Apesar de existirem alguns dados das vendas de motores elétricos disponíveis através da ABINEE (até 2003), estes não podem ser utilizados para definir com precisão a composição do mercado, devido a três fatores principais:

- As taxas de reparação e substituição variam com a potência do motor. Deste modo, dentro do volume de vendas anual de cada escala de potência, variam também as porcentagens que se destinam à substituição de motores já existentes por avaria ou à expansão do parque através da instalação de novas unidades;

- Não se conhece o volume de motores vendidos que se destinam a exportação;

- Não se conhece com exatidão a quantidade de motores vendidos a OEMs, e que voltam a entrar no mercado. 
Tabela 8.10.5 - Impacto da distribuição da potência na amostra para o consumo estimado

\begin{tabular}{|c|c|c|c|c|c|c|c|c|c|c|c|}
\hline $\begin{array}{c}\text { Tamanho } \\
\text { da amostra }\end{array}$ & $\begin{array}{c}\text { Média } \\
\text { potência } \\
\text { amostra } \\
\text { (CV) }\end{array}$ & $\begin{array}{l}\text { Potência } \\
\text { (CV) }\end{array}$ & Dist. & Nomotores & $\begin{array}{l}\text { Carreg. } \\
\text { médio }\end{array}$ & $\begin{array}{c}\text { Tempo de } \\
\text { operação } \\
\text { (horas) }\end{array}$ & $\begin{array}{l}\text { Num. } \\
\text { BDM otor }\end{array}$ & Rendimento & $\begin{array}{l}\text { Consumo unitário } \\
\text { por tipo de motor } \\
\text { (MWh) }\end{array}$ & $\begin{array}{l}\text { Consumo total } \\
\text { por tipo de motor } \\
\text { (M Wh) }\end{array}$ & $\begin{array}{l}\text { Consumo total } \\
\text { (M Wh) }\end{array}$ \\
\hline \multirow{3}{*}{300} & \multirow{3}{*}{78,255} & 60 & $33,30 \%$ & 100 & $75 \%$ & 5000 & 2313 & $92,2 \%$ & 239,32 & $23.931,67$ & \multirow{3}{*}{$93.454,30$} \\
\hline & & 75 & $33,30 \%$ & 100 & $75 \%$ & 5000 & 2315 & $92,0 \%$ & 299,80 & $29.979,62$ & \\
\hline & & 100 & $33,30 \%$ & 100 & $75 \%$ & 5000 & 2317 & $93,0 \%$ & 395,43 & $39.543,01$ & \\
\hline \multirow{3}{*}{300} & \multirow{3}{*}{68,5} & 60 & $60,00 \%$ & 180 & $75 \%$ & 5000 & 2313 & $92,2 \%$ & 239,32 & $43.077,01$ & \multirow{3}{*}{$81.921,57$} \\
\hline & & 75 & $30,00 \%$ & 90 & $75 \%$ & 5000 & 2315 & $92,0 \%$ & 299,80 & $26.981,66$ & \\
\hline & & 100 & $10,00 \%$ & 30 & $75 \%$ & 5000 & 2317 & $93,0 \%$ & 395,43 & $11.862,90$ & \\
\hline \multirow{2}{*}{\multicolumn{10}{|c|}{ Fonte: Elaboração própria, com base em BDMotor (2008) }} & Diferença (M Wh) & $11.532,73$ \\
\hline & & & & & & & & & & Diferença $(\%$ & $14,08 \%$ \\
\hline
\end{tabular}

Adicionalmente, seria muito interessante obter uma distribuição dos diversos motores existentes dentro de cada escala de potência. Como se pode ver no exemplo seguinte (Tabela 8.10.5), os valores obtidos para o consumo de um determinado escala de potência (51-100 CV) variam bastante consoante a distribuição por potência dos vários motores que a compõem, mesmo que a média se apresente semelhante.

\subsubsection{Distribuição de motores por carga suportada}

Do mesmo modo, seria também relevante descobrir valores mais precisos não só para a carga média suportada pelos diversos motores de diferentes escalas através dos diversos setores da indústria, como também para o modo como a distribuição dos valores de carga na população evolui à volta da média em cada caso.

Como se pode ver na Tabela 8.10.6, o modo como a carga varia em volta da média também pode representar uma variação importante numa eventual estimativa do consumo de um grupo de motores. Além disso, tendo em conta que a relação entre carga e rendimento não é linear, seria interessante obter dados relativamente ao desempenho dos diversos motores em mais do que três pontos de carga (50\%, 75\% e 100\%), como sucede no BDMotor. De fato, é bastante possível que uma grande parte dos motores de potências mais modestas opere a 
Tabela 8.10.6 - Impacto da distribuição da carga na amostra para o consumo estimado

\begin{tabular}{|c|c|c|c|c|c|c|c|c|c|c|c|}
\hline $\begin{array}{l}\text { Tamanho } \\
\text { da amostra }\end{array}$ & $\begin{array}{l}\text { Potência } \\
\text { (CV) }\end{array}$ & $\begin{array}{l}\text { Carreg. } \\
\text { Médio }\end{array}$ & Dist. & No motores & Carreg. & $\begin{array}{l}\text { Tempo de } \\
\text { operação } \\
\text { (horas) }\end{array}$ & $\begin{array}{l}\text { Num. } \\
\text { BDM otor }\end{array}$ & Rendimento & $\begin{array}{l}\text { Consumo unitário } \\
\text { por tipo de motor } \\
\text { (MWh) }\end{array}$ & $\begin{array}{l}\text { Consumo total } \\
\text { por tipo de motor } \\
\text { (MWh) }\end{array}$ & $\begin{array}{l}\text { Consumo total } \\
\text { (MWh) }\end{array}$ \\
\hline \multirow{3}{*}{300} & \multirow{3}{*}{1} & \multirow{3}{*}{$75 \%$} & $33,30 \%$ & 100 & $50 \%$ & 5000 & 2281 & $72,0 \%$ & 5,11 & 510,76 & \multirow{3}{*}{$1.447,86$} \\
\hline & & & $33,30 \%$ & 100 & $75 \%$ & 5000 & 2281 & $77,5 \%$ & 4,75 & 474,52 & \\
\hline & & & $33,30 \%$ & 100 & $100 \%$ & 5000 & 2281 & $79,5 \%$ & 4,63 & 462,58 & \\
\hline \multirow{3}{*}{300} & \multirow{3}{*}{1} & \multirow{3}{*}{$75 \%$} & $0,00 \%$ & 0 & $50 \%$ & 5000 & 2281 & $72,0 \%$ & 5,11 & 0,00 & \multirow{3}{*}{$1.423,55$} \\
\hline & & & $100,00 \%$ & 300 & $75 \%$ & 5000 & 2281 & $77,5 \%$ & 4,75 & $1.423,55$ & \\
\hline & & & $0,00 \%$ & 0 & $100 \%$ & 5000 & 2281 & $79,5 \%$ & 4,63 & 0,00 & \\
\hline \multirow{2}{*}{\multicolumn{10}{|c|}{ Fonte: Elaboração própria, com base em BDMotor (2008) }} & Diferença (M Wh) & 24,31 \\
\hline & & & & & & & & & & Diferença $(\%)$ & $1,71 \%$ \\
\hline
\end{tabular}

cargas inferiores a 50\%. No entanto, com os dados atualmente disponíveis não é possível estimar com precisão a economia que se poderia obter nesses casos. Embora se possa extrapolar os valores de rendimento para cargas inferiores a $50 \%$ através da curva de rendimento de cada motor, tal método é pouco preciso e previsivelmente introduziria grandes margens de erro nas estimativas efetuadas.

\subsubsection{Distribuição de motores por tipo (standard vs. alto rendimento)}

Conhecer a atual penetração de motores de alto rendimento é outro aspecto crucial para uma maior precisão no cálculo do potencial econômico existente através de trocas de motores no parque industrial brasileiro de motores. É provável que as taxas de penetração variem consoante os setores e escala de potência, mas não existem dados disponíveis em relação a esta matéria. 


\subsubsection{Distribuição de motores por tempo médio de operação anual}

O tempo médio de operação anual, por setor e categoria de potência, é um fator extremamente importante e que, na indústria brasileira, ainda não foi devidamente estudado. Conhecer estes dados com precisão seria um grande passo no sentido de se poder estimar com exatidão os ganhos potenciais que a troca por motores mais eficientes pode proporcionar.

Do mesmo modo, tal como já foi referido nas subseções anteriores, seria bastante interessante conhecer o modo como a distribuição desta variável evolui à volta do tempo médio de operação. Porém, neste caso, o impacto da distribuição desta variável à volta da média é praticamente nulo nas estimativas de consumo energético. A sua importância está relacionada com o impacto que o desconhecimento desta variável pode implicar na quantidade estimada de projetos viáveis de troca de motores. Como exemplo, pode-se tomar como exemplo uma categoria de potência que apresenta uma média anual de 5.000 horas de funcionamento. Dentro desta categoria, para se poder estimar a dimensão de um potencial mercado de trocas com precisão, é fundamental conhecer qual a porcentagem de motores que trabalham 2.000 horas ou menos, visto que, abaixo das 2.000 horas de tempo de operação anual, raramente se justifica a troca por um motor de alto rendimento. Por lógica simples (assumindo um número máximo de horas de operação por ano igual a 8.000), é fácil verificar que, para este caso específico, a porcentagem de motores dentro desta categoria que apresentam 2.000 horas ou menos de operação anual pode ir de $0 \%$ a 50\%, pelo que a incerteza na definição da dimensão do mercado é óbvia.

\subsubsection{Distribuição de motores por idade}

Não estão disponíveis dados sobre a idade média dos motores atualmente em operação no parque industrial brasileiro. Seria, no entanto, conveniente descobrir esta informação, visto que variações na idade média dos motores dentro de uma determinada categoria podem significar alterações significativas no potencial econômico existente nessa mesma categoria. Isto deve-se ao fato 
de, quanto mais velho for um motor, mais provável seja que apresente uma redução do seu rendimento, tanto pelas reparações a que já possa ter sido submetido como por mero desgaste dos materiais que o constituem, o que conduz a maiores perdas.

Seria também interessante conhecer, além da idade média dos motores em operação, o modo como a distribuição da idade evolui em volta da média.

\begin{tabular}{|c|c|c|c|c|c|c|c|c|c|c|}
\hline \multicolumn{10}{|c|}{ Tabela } & $\mathbf{8 . 1 0 . 7}$ \\
\hline
\end{tabular}

\subsubsection{Distribuição por número de pólos}

A distribuição por número de pólos é desconhecida. Como se pode verificar na Tabela 8.10.7, ao não se conhecer a distribuição de motores por número de pólos, pode-se facilmente incorrer em erros significativos nas estimativas de consumo de energia.

\subsubsection{Vida útil, taxas de avaria e taxas de reparação}

No que se refere às taxas de reparação por categoria de potência, foram utilizados dados relativos à indústria norte-americana (U.S. Department of Energy, 1998), por falta de dados sobre a indústria brasileira. Deste modo, e visto que, inseridas numa perspectiva de leilão de eficiência energética, parecem existir oportunidades consideráveis com a substituição de certos tipos de motores devido a avaria, seria interessante descobrir até que ponto estes dados da indústria norte-americana se aplica à indústria brasileira. Além disso, ao se 
estudar as taxas de reparação e substituição para cada categoria de potência, poder-se-ia determinar mais eficazmente o impacto que as mesmas têm no cálculo da vida útil média de cada tipo de motor.

Logicamente, seria também de grande interesse analisar o modo como evoluem as avarias ao longo da vida útil de um motor. Pode se concluir, de modo geral, que a probabilidade de avaria de um motor elétrico é bastante mais elevada durante algum tempo após entrar em operação, após o qual diminui vertiginosamente, voltando a aumentar à medida que o equipamento se aproxima da vida útil média do seu tipo de equipamento (Varshney, 2011). Inicialmente, pretendia-se introduzir esta curva no modelo criado, mas abandonou-se essa intenção por falta de informação de qualidade no que se refere ao modo como a curva evolui no caso dos motores de indução trifásicos (quanto tempo dura a fase inicial de maior probabilidade de avaria, a que ritmo e quão próximo da vida útil média acelera a taxa de avarias, etc).

Cruzando este tipo de dados com informações sobre a idade do parque industrial de motores, e recorrendo a dados mais fidedignos acerca das taxas de reparação e substituição, poder-se-á estimar com muito maior exatidão a dimensão do mercado de trocas de motores num eventual leilão de eficiência energética.

\subsubsection{Peso dos outros motores}

Não existem dados no que se refere ao consumo dos motores que não são de indução trifásicos na indústria brasileira. No caso da indústria norteamericana, existem setores nos quais os motores de corrente contínua representam até $30 \%$ do seu consumo de energia elétrica por força motriz (U.S. Department of Energy, 1998). Deste modo, seria importante estimar qual o peso efetivo dos motores de corrente contínua no consumo de energia elétrica nos vários setores industriais no Brasil.

Além disso, apesar de, muito provavelmente, o seu consumo total representar uma porcentagem muito pequena do total, seria interessante 
conhecer o peso que os motores com potências inferiores a $1 \mathrm{CV}$, tanto monofásicos como trifásicos, têm no consumo da indústria brasileira.

\subsubsection{OEMs - Original Equipment Manufacturers}

Segundo Soares (2008), a porcentagem de motores vendidos a OEMs anualmente ronda os 70\%. No entanto, desconhece-se a porcentagem efetiva de motores que são instalados na indústria como parte de equipamentos montados por OEMs. Não só seria importante ter uma estimativa para este valor, como seria relevante conhecer até que ponto as decisões de substituição e/ou reparação são afetadas pelo fato do motor estar inserido num equipamento OEM, visto que este fato pode ter impacto na dimensão do mercado de trocas para o leilão de eficiência energética.

\subsubsection{M\&V - Medição e Verificação}

De modo a que alguns dos pontos já referidos possam ser estudados, será importante dispor de meios que permitam confirmar, com um elevado nível de confiança, a qualidade dos dados obtidos. Portanto, paralelamente à coleta dos mais variados tipos de dados operacionais de motores, seria de grande relevância testar novos métodos ou técnicas de $M \& V$.

De modo a que o método de medição e verificação possa ser viável e a sua utilização possa vir a ter a anuência por parte dos diretores das unidades industriais, os métodos utilizados devem implicar o mínimo tempo possível de parada dos equipamentos, e não interferir no seu funcionamento. Além do mais, seria de grande valor se a coleta de dados pudesse ser efetuada de modo contínuo. Neste sentido, uma hipótese interessante seria a utilização de tecnologia RFID (Radio-Frequency Identification). Deste modo, e através de um servidor e uma eventual ligação à internet, seria possível não só registrar continuamente o fluxo de dados, como também monitorar esse mesmo fluxo - 0 que seria importante no caso de se querer garantir que, por exemplo, no caso de um contrato de desempenho inserido num eventual leilão de eficiência energética, os critérios operacionais foram respeitados ao longo do período posterior à instalação de equipamentos mais eficientes. 
Há ainda que salientar que este é um tópico de grande importância estratégica no que se refere ao futuro da eficiência energética no sistema energético brasileiro. Para a avaliação e financiamento de projetos de pesquisa e desenvolvimento, a ANEEL desenvolveu uma lista de temas estratégicos. Deste modo, após consulta aos temas definidos pela ANEEL como de importância estratégica, pode-se verificar que um eventual projeto de pesquisa e desenvolvimento envolvendo o desenvolvimento e teste de métodos de M\&V enquadrar-se-ia nos seguintes temas e subtemas estratégicos (ANEEL, 2008):

- EE - Eficiência Energética

o EE04 - Metodologias para avaliação de resultados de projetos de eficiência energética;

- QC - Qualidade e Confiabilidade dos Serviços de Energia Elétrica

o QC01 - Sistemas e técnicas de monitoração e gerenciamento da qualidade da energia elétrica;

- SC - Supervisão, Controle e Proteção de Sistemas de Energia Elétrica

o SC01 - Implementação de sistemas de controle (robusto, adaptativo e inteligente);

o SC02 - Análise dinâmica de sistemas em tempo real.

Considerando os vários temas e subtemas estratégicos em que este tema potencialmente se poderia enquadrar, pode-se assumir que um eventual projeto nesta área estaria bem colocado para receber o aval da ANEEL.

De modo que acaso algum projeto deste tipo venha a se concretizar, devese procurar saber quais os setores industriais teriam maior interesse em participar em conjunto com sua concessionária de energia elétrica (ex: através de contratos de distribuição de energia). Deste modo, tendo em vista o fato de um eventual projeto muito provavelmente vier a ser executado em cenário industrial, 
seria importante conseguir alavancar esta ligação já existente a certas unidades industriais. 


\section{REFERÊNCIAS BIBLIOGRÁFICAS}

1. ANEEL, Manual do Programa de Pesquisa e Desenvolvimento Tecnológico do Setor de Energia Elétrica, Brasília, DF, 2008

2. BAJAY, Sérgio V., Geração de energia elétrica no Brasil - necessidade de mudanças em algumas políticas e procedimentos de planejamento, Universidade Estadual de Campinas, Campinas, SP, 2009

3. CNI, Procel Indústria e Eletrobras, Oportunidades de Eficiência Energética para a Indústria - Experiências internacionais em eficiência energética para a indústria, Brasília, DF, 2010

4. CNI, Procel Indústria e Eletrobras, Oportunidades de Eficiência Energética para a Indústria - Alimentos e Bebidas, Brasília, DF, 2010

5. CNI, Procel Indústria e Eletrobras, Oportunidades de Eficiência Energética para a Indústria - Experiências internacionais em eficiência energética para a indústria, Brasília, DF, 2010

6. CNI, Procel Indústria e Eletrobras, Oportunidades de Eficiência Energética para a Indústria - Papel e Celulose, Brasília, DF, 2010

7. CNI, Procel Indústria e Eletrobras, Oportunidades de Eficiência Energética para a Indústria - Químico, Brasília, DF, 2010

8. CNI, Procel Indústria e Eletrobras, Oportunidades de Eficiência Energética para a Indústria - Experiências internacionais em eficiência energética para a indústria, Brasília, DF, 2010

9. CNI, Procel Indústria e Eletrobras, Oportunidades de Negócios para a Indústria em Projetos de Eficiência Energética com MDL Programático, Brasília, DF, 2010

10. CNI, Procel Indústria e Eletrobras, Experiências Internacionais em Eficiência Energética na Indústria, Brasília, DF, 2010

11. CNI, Matriz Energética: Cenários, Oportunidades e Desafios, Brasília, DF, 
2007

12. CNI, Matriz Energética e emissão de gases de estufa, Brasília, DF, 2008

13. CNI, Eficiência energética na indústria: o que foi feito no Brasil, oportunidades de redução de custos e experiência internacional, Brasília, DF, 2009

14. CNI, Procel Indústria e Eletrobras, Oportunidades de Eficiência Energética para a Indústria - Experiências internacionais em eficiência energética para a indústria, Brasília, DF, 2010

15. Eletrobras, Guia operacional de motores elétricos - versão 2000, Rio de Janeiro, RJ, 2000

16. Eletrobras, BDMotor, 2008

17. Efficiency Valuation Organization, International Performance Measurement and Verification Protocol, 2010

18. GARCIA, Agenor G.P., A inserção da eficiência na Matriz Energética Brasileira Propostas de políticas públicas para o estímulo à prática da eficiência energética nas empresas, São Paulo, SP, 2008

19. GARCIA, Agenor G.P., Leilão de Eficiência Energética no Brasil, Rio de Janeiro, RJ, 2008

20. GARCIA, Agenor G.P. et al, Avaliação dos Índices de Eficiência Energética para Motores Trifásicos de Indução, Rio de Janeiro, RJ, 2005

21.JÚNIOR, Norberto A., Motores de Alto Rendimento - Dimensionamento e Viabilidade Econômica, 2003

22. LEITE, Sidimar Q., Projeções para a demanda por energia elétrica no Brasil, 2006-2015, Rio de Janeiro, RJ, 2006

23. Ministério de Minas e Energia, Projeção da demanda de energia elétrica para os próximos 10 anos (2011-2020), Rio de Janeiro, RJ, 2011

24. Ministério de Minas e Energia, Plano Nacional de Eficiência Energética - 
Premissas e Diretrizes Básicas na Elaboração do Plano, Brasília, DF, 2010

25. Ministério de Minas e Energia, Balanço Energético Nacional 2010, Brasília, DF, 2010

26. Ministério de Minas e Energia, Plano Decenal de Expansão de Energia 2019, Brasília, DF, 2010

27. Ministério de Minas e Energia, Plano Nacional de Energia 2030, Brasília, DF, 2007

28. Ministério de Minas e Energia, Balanço de Energia Útil - BEU 2005, Brasília, DF, 2005

29. PEREIRA, Luís A., Análise Econômica da Aplicação de Motores de Indução de Alto Rendimento, PUCRS, data desconhecida

30. SCHAEFFER, Roberto, et al, Avaliação dos Índices de Eficiência Energética para Motores Trifásicos de Indução, Rio de Janeiro, RJ, 2005

31. SOARES, G.., Main Brazilian Industrial Energy Efficiency Activities, conforme apresentado na Motor Summit 08, Zurique, 2008

32. VARSHNEY, Lokesh, et al, Performance and reliability evaluation of induction machines: an overview, Julho 2011 


\section{Micerino, Fabio Jose}

Impacto da utilização de motores de alto rendimento e sua aplicação no leilão de eficiência energética / F.J. Micerino. -- São Paulo, 2012.

$121 \mathrm{p}$.

Dissertação (Mestrado) - Escola Politécnica da Universidade de São Paulo. Departamento de Engenharia de Energia e Automação Elétricas.

1. Motores elétricos (Rendimento) 2. Leilão 3. Eficiência energética i. Universidade de São Paulo. Escola Politécnica. Departamento de Engenharia de Energia e Automação Elétricas II. t. 